\title{
WestVirginiaUniversity
}

THE RESEARCH REPOSITORY @ WVU

Graduate Theses, Dissertations, and Problem Reports

2010

\section{Hydroclimate reconstructions of the Potomac River Basin using tree rings}

\author{
Richard Stockton Maxwell \\ West Virginia University
}

Follow this and additional works at: https://researchrepository.wvu.edu/etd

\section{Recommended Citation}

Maxwell, Richard Stockton, "Hydroclimate reconstructions of the Potomac River Basin using tree rings" (2010). Graduate Theses, Dissertations, and Problem Reports. 3113.

https://researchrepository.wvu.edu/etd/3113

This Dissertation is protected by copyright and/or related rights. It has been brought to you by the The Research Repository @ WVU with permission from the rights-holder(s). You are free to use this Dissertation in any way that is permitted by the copyright and related rights legislation that applies to your use. For other uses you must obtain permission from the rights-holder(s) directly, unless additional rights are indicated by a Creative Commons license in the record and/ or on the work itself. This Dissertation has been accepted for inclusion in WVU Graduate Theses, Dissertations, and Problem Reports collection by an authorized administrator of The Research Repository @ WVU.

For more information, please contact researchrepository@mail.wvu.edu. 


\title{
Hydroclimate Reconstructions of the Potomac River Basin Using Tree Rings
}

\author{
Richard Stockton Maxwell \\ Dissertation submitted to the \\ Eberly College of Arts and Sciences \\ at West Virginia University \\ in partial fulfillment of the requirements \\ for the degree of \\ Doctor of Philosophy \\ In \\ Geography \\ Amy Hessl, Ph.D., Chair \\ Steven Kite, Ph.D. \\ Rick Landenberger, Ph.D. \\ Jim Rentch, Ph.D. \\ Eric Heitzman, Ph.D. \\ Department of Geology and Geography \\ Morgantown, West Virginia \\ 2010
}

Keywords: climate, eastern redcedar, streamflow, dendrochronology

Copyright 2010 Richard Stockton Maxwell 


\section{ABSTRACT \\ Hydroclimate Reconstructions of the Potomac River Basin using Tree Rings Richard Stockton Maxwell}

The following dissertation is composed of three separate manuscripts with the overall theme of hydroclimate reconstructions of the Potomac River Basin. The first manuscript investigated two methods of crossdating eastern redcedar (Juniperus virginiana L.) and examined the dendroclimatic response of earlywood, latewood, and total ring-width. In the second manuscript, May precipitation for West Virginia Climate Region 6 was reconstructed using two millennial-length eastern redcedar chronologies from 750-1998. Comparisons were made to other paleoclimate proxy records of moisture in the Mid-Atlantic Region. The final manuscript focused on a multi-species reconstruction of Potomac River streamflow from 950-2001. In this manuscript, species importance in the reconstruction model was examined and the frequency, intensity, and duration of drought and pluvial events were calculated for water resources management. Each manuscript, or chapter, has its own abstract and has been formatted for publication in a specific journal. 


\section{Acknowledgements}

I would like to thank my advisor, Amy Hessl, for her knowledge, guidance, and support over the past four years. She has helped me become a better scientist and person. My labmates, Tom, Josh, and Pete, kept me sane throughout graduate school. Nothing that a PBR couldn't cure. And to my wife, Megan, thank you for loving me and keeping me honest.

I would like to thank the NASA West Virginia Space Grant Consortium, the Eberly College of Arts and Sciences, the Explorers Club, and the National Science Foundation for generously providing the funding needed to complete my research. Permissions and logistical support was provided by the Monongahela National Forest, the George Washington National Forest, the Nature Conservancy, the West Virginia Natural Heritage Program. Finally, thanks to Tom and Eve Firor for allowing me to sample on Cedar Knob, the site where it all began. 


\section{Table of Contents}

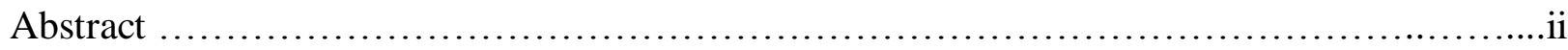

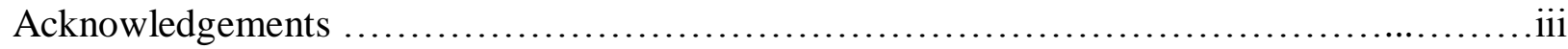

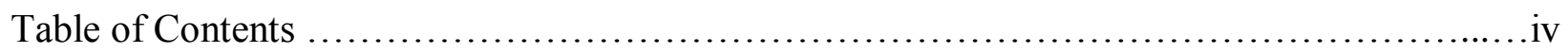

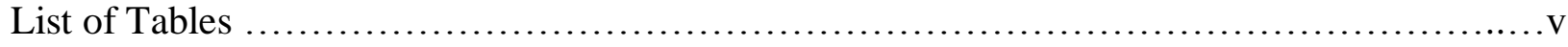

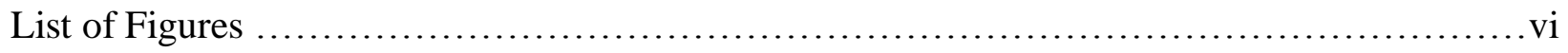

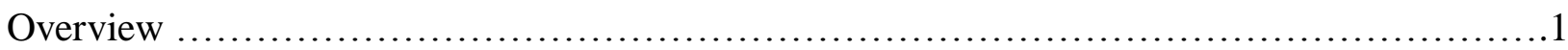

Chapter 1: A Comparison of Two Techniques for Measuring and Crossdating Tree Rings .........5

Chapter 2: A 1248-year reconstruction of May precipitation for the Mid-Atlantic Region using

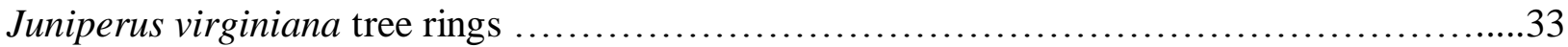

Chapter 3: A Multi-Species Tree-Ring Reconstruction of Potomac River Streamflow (950-2001)

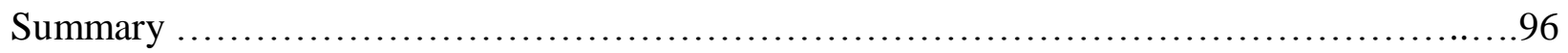

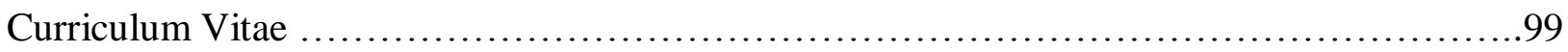




\section{List of Tables}

\section{Chapter One}

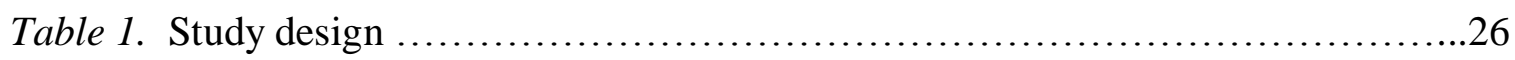

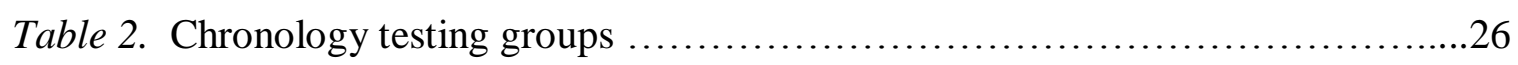

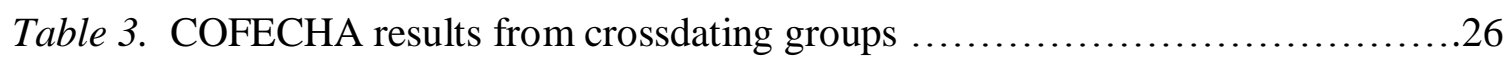

Table 4. Chronology correlations with Palmer Drought Severity Index ..............27

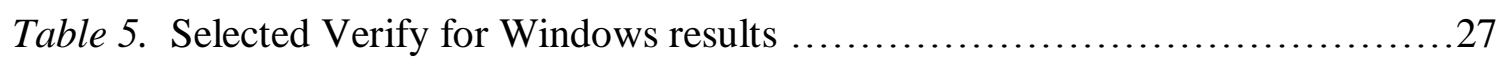

Table 6. Tukey's HSD multiple comparisons test of latewood chronologies ...........28

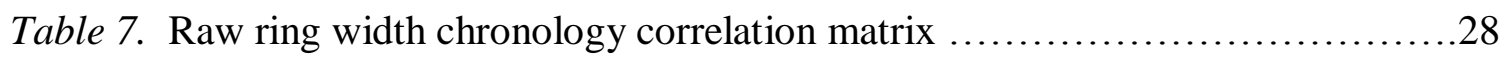

Chapter Two

Table 1. Calibration and verification statistics for the May precipitation model .........56

Table 2. Top 10 driest and wettest years and non-overlapping 10-year events for the May precipitation reconstruction (AD 750-1998) ..........................56

Chapter Three

Table 1. Chronologies used in the Potomac River streamflow reconstruction ............88

Table 2. Lowest $n$-year moving averages of the reconstructed (950-2001) and actual

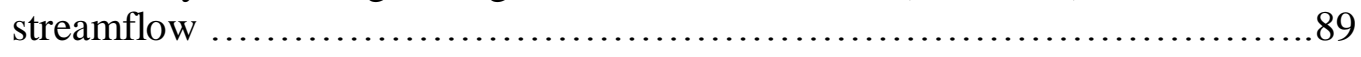




\section{List of Figures}

\section{Chapter One}

Figure 1. Location of sampling site ...........................................

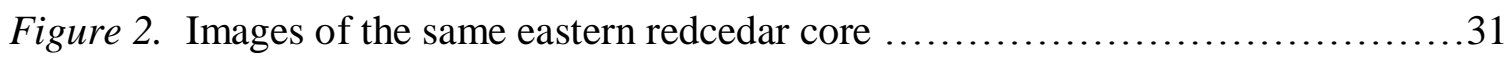

Figure 3. Total width (a), earlywood (b), and latewood (c) raw chronologies for Velmex, WinDENDRO, Technician 1, and Technician 2 chronology testing groups .............32

\section{Chapter Two}

Figure 1. Map of the Mid-Atlantic Region including the Smoke Hole and Cedar Knob eastern redcedar tree-ring sampling locations, West Virginia Climate Region 6, Stahle et al.'s (1998) bald cypress tree-ring sampling locations, the Virginia/North Carolina PHDI Climate Region reconstructed by Stahle et al., and the location of Cronin et al.'s (2000) Chesapeake Bay salinity record

Figure 2. Residual chronologies for the Smoke Hole (a) and Cedar Knob (b) locations with sample size and expressed population signal (EPS)

Figure 3. (a) Correlation analysis results of PC1 and West Virginia Climate Region 6 temperature and precipitation. The capitalized months are from the previous year. $(b)$ Correlation analysis between PC1 and May precipitation using a 35-year moving window (black line) to assess time stability of the relationship and instrumental winter North Atlantic Oscillation (NAO; Jones et al. 1997) index smoothed with a 10 -year $4^{\text {th }}$ order

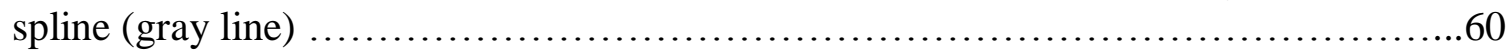

Figure 4. Calibration and verification of modeled May precipitation (gray line) compared to instrumental record (black line)

Figure 5. Full May precipitation reconstruction from AD 750-1998. The gray line represents the annual predicted values

Figure 6. Box-and-whisker plots $\left(10^{\text {th }}, 25^{\text {th }}, 50^{\text {th }}, 75^{\text {th }}\right.$, and $90^{\text {th }}$ percentiles $)$ were calculated for each century of the May precipitation reconstruction and the $20^{\text {th }}$ century instrumental period 62

Figure 7. Regional comparison of the May precipitation reconstruction $(a)$ to Stahle et al.'s (1998) July PHDI reconstruction (b) and Cronin et al.'s (2000) salinity reconstruction $(c)$ 


\section{Chapter Three}

Figure 1. Maps show the location of 27 tree-ring sites used as predictors in the reconstruction. Sites are differentiated by species (in the left panel) and by beta weights

for all chronologies used in the common period 1700-1976 (in the right panel)

Figure 2. Monthly Potomac River streamflow at Point of Rocks, Maryland calculated from 1895-2007 data

Figure 3. (a) The reconstruction of mean May-September Potomac River streamflow and the number of predictor chronologies, and (b) the time-varying calibration and verification statistics for nested PCR models from 950-2001

Figure 4. Nested PCR models (gray lines) during the calibration and verification period. Only nested models from the 950-2001 period are shown

Figure 5. Histograms showing the frequency of $n$-year drought and pluvial events (years below or above the median streamflow) for the (a) reconstruction and (b) instrumental period

Figure 6. Box-and-whisker plots $\left(10^{\text {th }}, 25^{\text {th }}, 50^{\text {th }}, 75^{\text {th }}\right.$, and $90^{\text {th }}$ percentiles $)$ were calculated for each half century of the back-transformed streamflow reconstruction and the back-transformed instrumental period (1907-2007)

Figure 7. Comparison of the May-September reconstruction of Potomac River streamflow (blue line; current study), Cook and Jacoby's previous June-August reconstruction of the same streamflow gage (red line), and the actual untransformed streamflow record 


\section{Overview}

The dissertation that you are about to read is composed of three separate but related manuscripts written and formatted for specific academic journals. The overarching theme of my research is "Hydroclimate reconstructions of the Potomac River Basin using tree rings". As sometimes happens through the course of investigation, my research evolved from its original conception in my dissertation proposal. However, I believe the resulting manuscripts investigated the compelling questions raised by the data while appropriately addressing my original objectives. The primary objectives of my research were to:

1. Reconstruct the streamflow (and hydroclimate) of the Potomac River for the last 1000 years using $J$. virginiana tree-ring metrics (i.e., total ring width, earlywood width, and latewood width).

2. Utilize a multi-species approach to increase the seasonal window of hydroclimate reconstructions for the last 300 years.

3. Evaluate the instrumental record of streamflow in the context of the past 1000 years of the proxy record and determine how the frequency, intensity, and duration of extreme events (i.e., droughts and pluvials) have changed over time.

4. Transfer streamflow and hydroclimate reconstructions to water resource managers in the Potomac River Basin to foster integration of tree-ring data into water resource modeling efforts in the eastern United States.

Initially, Josh Wixom, Amy Hessl, and I debated the best way to measure and crossdate eastern redcedar tree rings including earlywood, latewood, and total ring-width. Prior to Objective 1, I designed a study based on the core principle of dendrochronology, crossdating. The study compared two techniques for measuring and crossdating tree rings using eastern 
redcedar as a case study. We used a pseudo-2x2 study design comparing the traditional skeleton plot/Velmex technique to the semi-automatic image analysis program WinDENDRO across two technicians. Crossdating was evaluated in COFECHA and with correlation analyses between compiled chronologies and Palmer Drought Severity Index (PDSI). Raw measurements of total, earlywood, and latewood widths from the two methods were analyzed using the Verify for Windows program, ANOVA, and correlation matrices. Total ring width and earlywood width were well correlated between techniques and technicians but questionable ring boundaries from WinDENDRO should be checked under a stereoscope. Latewood widths were significantly different between techniques and technicians; therefore, we do not recommend combining latewood measurements for dendrochronological analysis. A standard definition of the earlywood-latewood boundary that can be replicated across technicians is needed to combine latewood measurements from the Velmex and WinDENDRO systems. Also, our results suggest that eastern redcedar latewood widths should not be utilized in dendroclimatic analysis because of the limited variability of latewood widths. This sub-study became the first manuscript of my dissertation.

I concentrated solely on the total ring-width of eastern redcedar and its dendroclimatic response for Objective 1 and my second manuscript. I developed a 1248-year reconstruction of May precipitation (AD 750-1998) for the Mid-Atlantic Region of the United States. The reconstruction was based on the first principal component (PC1) of two millennial-length eastern redcedar (Juniperus virginiana) tree-ring chronologies collected from rocky, limestone sites in the Ridge and Valley province of West Virginia. A split-calibration linear regression model accounted for $32 \%$ of the variance in the instrumental record and was stable through time. The model was well verified by the reduction of error $(\mathrm{RE}=0.33)$ and coefficient of efficiency $(\mathrm{CE}=$ 
0.30) statistics. Centennial-length changes in precipitation were rare but wetter than median conditions and drier than median conditions occurred during the Medieval Warm Epoch (AD 1000-1300) and the Little Ice Age (AD 1450-1850), respectively. The full reconstruction contained substantial inter-annual and decadal variability, however, the $19^{\text {th }}$ and $20^{\text {th }}$ centuries recorded the greatest number of annual and decadal extreme wet and dry periods (Objective 3). A comparison of the May precipitation reconstruction to other regional reconstructions of July Palmer Hydrologic Drought Index and Chesapeake Bay salinity showed that not only did drought and pluvial events extend into the Ridge and Valley province but they also began early in the growing season. A positive correlation between PC1 and the winter North Atlantic Oscillation Index indicates that eastern redcedar's response to May precipitation is mediated by winter temperature.

Finally, I utilized multi-species approach for my final manuscript, covering Objectives 2, 3, and 4. Mean May-September Potomac River streamflow was reconstructed from 950-2001 using a network of tree-ring chronologies $(n=27)$ representing multiple species. We chose a nested principal components reconstruction model to maximize the use of available chronologies backward in time. Explained variance during the period of calibration ranged from 20\% to 53\% depending on the number and species of chronologies available in each 25-yr time-step. The model was verified by two rigorous goodness-of-fit tests, the coefficient of efficiency (CE) and the reduction of error statistic (RE). The RE and CE never fell below zero, suggesting the model had explanatory power over the entire period of reconstruction. Beta weights indicated a loss of explained variance during the 1550-1700 period that we hypothesize was caused by the reduction in total number of predictor chronologies and important predictor species. Frequency, intensity, and duration of drought and pluvial events were examined to aid water resource managers. We 
found that the instrumental period did not represent adequately the full range of annual to multidecadal variability present in the reconstruction. Our reconstruction of mean May-September Potomac River streamflow was a significant improvement to the previous reconstruction because it expanded the seasonal window, lengthened the record by 780 years, and better replicated the mean and variance of the instrumental record. By capitalizing on variable phenologies and treegrowth responses to climate, multi-species reconstructions may provide significantly more information about past hydroclimate, especially in regions with low aridity and high tree species diversity. The final manuscript will be broken into two separate manuscripts for publication. The first will concentrate on the multi-species method of streamflow reconstruction in the MidAtlantic Region. The second will focus on the integration of tree-ring data into water resources management. Thanks for reading. I hope you enjoy my dissertation. 


\title{
Chapter 1: A Comparison of Two Techniques for Measuring and Crossdating Tree Rings
}

\author{
R. Stockton Maxwell*, Joshua A. Wixom, and Amy E. Hessl \\ Department of Geology and Geography \\ West Virginia University
}

\author{
*Corresponding Author \\ West Virginia University \\ Department of Geology and Geography \\ P.O. Box 6300 \\ Morgantown, WV 26506-6300
}

Email: stockton.maxwell@gmail.com 


\section{Summary}

Crossdating is the core principle of dendrochronology. Our study compared two techniques for measuring and crossdating tree rings using eastern redcedar as a case study. We used a pseudo$2 \times 2$ study design comparing the traditional skeleton plot/Velmex technique to the semiautomatic image analysis program WinDENDRO across two technicians. Crossdating was evaluated in COFECHA and with correlation analyses between compiled chronologies and Palmer Drought Severity Index (PDSI). Raw measurements of total, earlywood, and latewood widths from the two methods were analyzed using the Verify for Windows program, ANOVA, and correlation matrices. Total ring width and earlywood width were well correlated between techniques and technicians but questionable ring boundaries from WinDENDRO should be checked under a stereoscope. Latewood widths were significantly different between techniques and technicians; therefore, we do not recommend combining latewood measurements for dendrochronological analysis. A standard definition of the earlywood-latewood boundary that can be replicated across technicians is needed to combine latewood measurements from the Velmex and WinDENDRO systems. Also, our results suggest that eastern redcedar latewood widths should not be utilized in dendroclimatic analysis because of the limited variability of latewood widths.

Keywords: earlywood, eastern redcedar, latewood, Velmex, WinDENDRO 


\section{Introduction}

A.E. Douglass recognized early in the $20^{\text {th }}$ century that accurate annual dating of tree rings could be achieved by matching patterns of narrow and wide rings across trees at a site. Pattern matching in tree rings, or crossdating, became the fundamental principle of the science of dendrochronology (H.C. Fritts 1976; E.R. Cook \& Kairiukstis 1990; Speer 2010). Crossdating is possible because climate or other regional environmental factors that limit annual radial growth produce common year-to-year variation in tree rings across a large number of individuals. The accurate interpretation of environmental signals (e.g., insect outbreak, fire, and drought) recorded in annual tree rings is dependent on the quality of crossdating. Growth anomalies, such as false, missing, and micro tree rings, require technicians to scrutinize samples to achieve accurate annual dating. The techniques used to implement crossdating continue to evolve with applications to new species and regions, and changes in technology. Currently, four main methods of crossdating are utilized in dendrochronology: 1) skeleton plotting, 2) the list method, 3) the memorization method, and 4) image analysis (Speer 2010). Technicians often begin with a visual method such as skeleton plotting and move towards the memorization method as marker rings are identified. Following visual crossdating, annual increments are measured using a sliding measuring stage (e.g., Velmex) and statistical accuracy of crossdating is checked using the program COFECHA (Grissino-Mayer 2001; Holmes 1983). COFECHA serves as a second technician by correlating measured segments of individual tree-ring series to a master chronology composed of the remaining series from a site.

More recently, semi-automatic image analysis programs such as WinDENDRO have been utilized for measurement and visual crossdating. WinDENDRO detects boundaries between tree rings and the transition from earlywood to latewood cells based on changes in light 
intensity of an image (Regent Instruments Canada Inc. 2009). The process is semi-automatic because ring anomalies such as false rings or micro-rings require the user to manually adjust boundaries. Virtual skeleton plots and comparisons against a previously constructed master (or reference) chronology are used to crossdate images of increment cores. Measurements are exported from WinDENDRO and accuracy of crossdating can then be assessed in COFECHA. In each method, accuracy of measurements from a technician should be evaluated by periodically comparing a sample of tree-ring measurements from one technician to a series of known accuracy from another technician. Simple descriptive statistics and regression analysis can be conducted to identify errors in measurement (Lawrence \& Grissino-Mayer 2001).

Both measuring stages and image analysis programs can be used to measure sub-annual increments of earlywood and latewood. While annual boundaries are easily identified under a stereoscope or in a high-resolution image, definition of the earlywood-latewood (EW-LW) boundary differs between measurement methods. In a high-resolution image (3200 dpi) of a tree-ring sample, thickening of cells walls cannot be viewed with the same clarity as under a stereoscope. Therefore, image analysis must rely on light intensity to define the EW-LW boundary. The discrepancy between boundary definitions may produce measurement differences for the same tree-ring series. The total-, earlywood-, and latewood-width chronologies developed from both measuring stages and image analysis programs have proved useful across a range of dendrochronological applications (Meko \& Baisan 2001; e.g., Laroque \& Smith 1999; Gedalof \& Smith 2001) and have been distributed on the International Tree-Ring Data Bank (2010) for further comparison and meta-analyses. However, we have found no published account comparing the accuracy of tree-ring measurements or crossdating between techniques. 
Crossdating some species is difficult due to the presence of growth anomalies. For example, tree rings of eastern redcedar (Juniperus virginiana L.) can be difficult to crossdate because of the prevalence of false rings during the early years of growth and micro and absent rings throughout the life of the tree. Despite the impediment to crossdating caused by growth anomalies, several researchers have investigated the dendrochronological potential of eastern redcedar (Guyette et al. 1980; Hawley 1937; Larson 1997). Eastern redcedar is particularly useful for dendroclimatic analysis because: 1) it is one of three long-lived (> 700 years) eastern tree species (Brown 1996); 2) it grows on open and undisturbed micro-environments that are moisture limited; and 3) the heartwood is resistant to decay allowing extension of chronologies with sub-fossil and archaeological samples (Guyette et al. 1980). We chose eastern redcedar for our comparative analysis because of these characteristics and the species' potential for climate reconstruction. Additionally, no previous research on eastern redcedar has explored the dendroclimatic potential of earlywood- and latewood-width measurements from this species.

The explanatory power and validity of tree-ring reconstructions of environmental variables is dependent on the accuracy of tree-ring measurements and crossdating. To this end, the objective of our study was to compare the traditional technique of skeleton plotting and Velmex measurements to the semi-automatic image analysis program WinDENDRO for measurement and crossdating accuracy. We collected eastern redcedar increment cores from a rocky, limestone site in West Virginia, USA and compared total, earlywood, and latewood ring widths across two technicians. We utilized a pseudo-2x2 study design and analyzed the data with four methods: 1) COFECHA analysis, 2) Verify for Windows analysis, 3) ANOVA of chronologies across testing groups, and 4) chronology correlations with Palmer Drought Severity Index (PDSI). 


\section{Methods}

\section{Tree-Ring Data}

Forty increment cores were collected from live eastern redcedar trees $(\mathrm{N}=23$ trees) growing on a limestone barren located in the Monongahela National Forest in Pendleton County, West Virginia, USA (Fig. 1; 38 $53^{\prime} 02^{\prime \prime} \mathrm{N} 79^{\circ} 14^{\prime} 12^{\prime \prime} \mathrm{W} ; 650$ m elevation). The site is situated in the rainshadow of the Appalachian Mountains receiving an average of $<90 \mathrm{~cm}$ of precipitation each year (National Oceanic and Atmospheric Administration 2009). The slope of the sample site is moderate to steep with a southwestern aspect. Trees grow in rocky, shallow soils formed from cherty Helderberg and argillaceous Tonoloway limestone parent material (Sites 1973). In addition to eastern redcedar, red oak (Quercus rubra L.), chinquapin oak (Quercus muehlenbergii Englem), ironwood (Ostrya virginiana Mill.), and eastern white cedar (Thuja occidentalis L.) populate the site. Tree density at the site is low resulting in little competition within or between species.

Samples were returned to the lab to be dried, mounted, and sanded according to standard dendrochronological techniques (Stokes \& Smiley 1968). Progressively finer grades of sandpaper (80-1000 grit) were used to surface the increment cores until the individual cells were visible under a stereoscope. Then, each increment core was scanned at $3200 \mathrm{dpi}$ (interpolated from 2400 true dpi) using an Epson Expression 10000XL flatbed scanner to be analyzed in the image analysis program WinDENDRO (Fig. 2; Regent Instruments Canada Inc. 2009). File sizes for individual series ranged from 40 to 150 megabytes.

Palmer Drought Severity Index data (1895-2007) for West Virginia Climate Region 6 were obtained from the National Climatic Data Center (2009). PDSI data were used in a correlation function analysis with annual tree-ring growth. PDSI was used as an index of 
drought conditions and is based on regional precipitation, temperature, and potential evapotranspiration patterns (Palmer 1965).

\section{Study Design}

A pseudo-2x2 factorial design was used to compare two methods (i.e., Velmex vs. WinDENDRO) of crossdating across two technicians (Table 1). The study design cannot be considered a standard factorial design because technicians did not repeat crossdating on the same set of increment cores using each method. Thus, Technician 1 used the Velmex technique to crossdate cores 1-20 while Technician 2 used the same technique to crossdate cores 21-40. In the second round of crossdating, both technicians used the WinDENDRO technique but switched sets of cores. We chose the pseudo-design because the repetition of crossdating via a second method using the same set of cores would introduce bias and would not allow for an even comparison of techniques. Crossdating experience levels varied between technicians.

Technician 1 had 4 years experience while Technician 2 had $<1$ year experience.

The combined skeleton-plotting/Velmex approach (henceforth called the Velmex technique) involved the traditional method of technicians marking patterns of narrow rings on graph paper for individual cores and comparing each series to a master chronology previously developed for the site. After crossdating several cores via skeleton-plotting, technicians were allowed to use the memorization technique to crossdate the remaining cores in their set. Then, technicians measured earlywood and latewood widths (combined for total ring width) for each series using a Velmex Measuring System (0.01 mm precision; Velmex Inc 2009) combined with the program Measure J2X (Voor Tech Consulting 2008). A general definition of the EW-LW boundary was defined by both technicians as the area in the annual ring where: 1) cell walls thickened; 2) cells narrowed in diameter; and 3) cells became darker in color (Vaganov et al. 
2006). For measurements with the Velmex, technicians discussed and compared placement of the EW-LW boundary prior to measurement. Accuracy of crossdating is checked by the program COFECHA (Grissino-Mayer 2001; Holmes 1983) and dating discrepancies are corrected by each technician independently.

The second technique used the semi-automatic image analysis program WinDENDRO. Again, WinDENDRO detects annual and intra-annual ring boundaries based on changes in light intensity of an image and requires manual adjustment to ring boundaries to account for growth anomalies (Regent Instruments Canada Inc. 2009). Technicians discussed and compared placement of the EW-LW boundary prior to measurement in the program. We modified the EWLW definition parameter in the program to $25 \%$ of the difference between the maximum and minimum light intensity based on previous experience with the software and species. Earlywood and latewood widths (combined for total ring width) were measured automatically for each treering sample. Digital skeleton plots and comparisons against a previously constructed master chronology for the site are used to crossdate samples. The program COFECHA assesses the accuracy of crossdating and discrepancies were corrected in WinDENDRO by each technician independently.

\section{Data Analysis}

\section{Crossdating}

Simple comparisons were made for output tables from COFECHA between crossdating techniques and across technicians. Comparisons were used to determine if differences existed between methods of crossdating on the same set of cores. In COFECHA, we used the default analysis settings: 1) 32-year cubic smoothing spline with 50\% wavelength cutoff for filtering; 2) examination of 50-year segments lagged 25 years; 3 ) autoregressive modeling turned on; 4) 
transformation of series to logarithms; and 5) 0.3281 critical level in the correlation analysis (Grissino-Mayer 2001). We concentrated mainly on the following output options: 1) tree-ring series correlations with the master chronology; 2) mean sensitivity, a measure of the year-to-year ring variability within a sample; and 3) number of "A" flagged segments (i.e., 50-year sections of an individual tree-ring series with low correlation to the master chronology).

Raw ring widths for total, earlywood, and latewood measurements of the 40 cores used in the study were pooled into four chronology testing groups: 1) all Velmex cores; 2) all WinDENDRO cores; 3 ) all cores from Technician 1; and 4) all cores from Technician 2 (Table 2). Raw ring-width series were standardized using a 150-yr smoothing spline (fixed 50\% variance cutoff) and compiled into total-, earlywood-, and latewood-width chronologies using the program ARSTAN for the four chronology testing groups for a total of 12 individual chronologies (E. R. Cook 1985). The standardized chronologies from each group were correlated with PDSI from West Virginia Climate Region 6 to determine if the combination of tree-ring series across methods and technicians had an effect on correlations with climate.

\section{Measurements}

Pairs of cores were compared in the program Verify for Windows to check the accuracy of measurement between crossdating techniques (Lawrence \& Grissino-Mayer 2001). Verify for Windows compares raw ring-width measurements for the same series and calculates a host of descriptive and regression statistics to determine if measurements are statistically different from each other. From the program, we used correlations of measurement series between crossdating techniques, verification analysis based on Fritts (1976), and outlier detection (Lawrence \& Grissino-Mayer 2001). In the verification analysis, a series was rejected if a threshold (0.01 $\mathrm{mm})$ of the average squared difference between the series was exceeded. An outlier was identified if 
the absolute difference between measurements for a particular year was greater than 2.5 times the mean absolute difference for the series pair. Comparisons in Verify for Windows were made for total-, earlywood-, and latewood-width measurement series. Finally, an analysis of variance (ANOVA) and a correlation matrix for the four chronology testing groups were calculated using raw measurements of total, earlywood, and latewood widths. Ring-width chronologies were plotted over time to visually determine if combining series across methods and technicians resulted in time series with similar means and variances.

\section{Results}

\section{Crossdating}

Output tables from COFECHA for total-width measurement series showed small differences in the accuracy of crossdating across technicians and crossdating methods (Table 3). Technician 1 had higher series intercorrelations than Technician 2 regardless of crossdating method, though these did not vary significantly. The greatest differences between methods were seen in the number of "A" flagged segments. Overall, the WinDENDRO technique had a greater number of flags than the Velmex technique and Technician 2 had more flags than Technician 1. Better performance of Technician 1 is likely the effect of more crossdating experience than Technician 2 and not a difference in methods.

We compared the raw measurements of each series pair to determine if series with and without flags were crossdated properly. We found 11 discrepancies in dating between methods indicating that 1 of the series in each of the 11 pairs were misdated (Table 3). However, only 3 of 11 misdated series contained flagged segments in COFECHA. Further inspection of dating discrepancies revealed 4 misdated series in the Velmex technique and 7 in WinDENDRO. Most 
crossdating errors (10 of 11) occurred early in the first 50-year segment and had little effect on the series correlation with the master. The effect of technician experience was confirmed with 10 of 11 series misdated by Technician 2 .

Total-, earlywood-, and latewood-width standard chronologies for the four testing groups were regressed against West Virginia Climate Region 6 PDSI (Table 4). As expected, total width and earlywood chronologies across techniques and technicians were significantly correlated with growing season (May-August) and annual PDSI. The significant correlation in March for both groups is the positive effect of warmer spring temperatures on growth. The latewood results are more difficult to interpret. The WinDENDRO and Technician 2 latewood chronologies were significantly correlated with February-August and annual PDSI. The Velmex and Technician 1 latewood chronologies were not significantly correlated with PDSI with one exception (Technician 1 and May PDSI). The latewood correlation results suggest that technicians were defining the EW-LW boundary in a different manner.

\section{Measurements}

Measurement series for individual cores were compared between crossdating methods in the program Verify for Windows (Table 5). Total width measurements were well correlated (mean $r=0.95$ ) between the Velmex and WinDENDRO techniques. The average mean squared difference for total width $(0.011 \mathrm{~mm})$ confirmed the similarity of measurements between techniques. However, 8 of 40 series were rejected during the verification test (i.e., exceeded the $0.01 \mathrm{~mm}$ mean squared difference verification threshold), indicating differences in measurement, and possibly crossdating. Approximately 7\% (803) of the 11,779 ring pairs were detected as outliers. Verify for Windows results were similar for earlywood measurements because earlywood widths comprised an average of $92 \%$ of annual tree growth (Table 5). 
We further analyzed the 8 total-width series pairs rejected during the verification test to determine if outliers in these series were indicative of errors in crossdating or purely errors in measurement. We found that 7 of the 8 rejected series were identified in the previous COFECHA analysis as misdated (Table 3). These rejected series did not have corresponding "A" flags in COFECHA for segments containing the outliers, suggesting to the technician that cores were properly crossdated. The remaining rejected series pair was crossdated correctly but contained several measurement discrepancies near growth anomalies and gaps in the wood.

Comparisons of latewood measurements in the Verify for Windows program again are more difficult to interpret (Table 5). Correlations between measurement pairs averaged 0.224 ( $\sigma$ $=0.147$ ) and 3\% (351) of the 11,779 ring pairs were detected as outliers. It is clear that latewood was interpreted differently between techniques but the reduced number of outliers and $100 \%$ acceptance of series in the verification threshold test suggested that measurements were similar. Closer inspection of measurement series and average squared differences revealed that the likelihood of detecting an outlier or exceeding the verification threshold of $0.01 \mathrm{~mm}$ average squared difference was reduced because of the small range of measurement values for latewood (Table 5).

The ANOVA and the correlation matrices of the four raw chronology combinations reinforced the results from Verify for Windows. The ANOVA detected no significant difference between chronology groups for total-width $[F(3,2048)=0.115, \mathrm{p}=0.951]$ and earlywoodwidth $[F(2,2048)=0.237, \mathrm{p}=0.871]$ chronologies between techniques and technicians. However, latewood-width chronologies were significantly different in the $\operatorname{ANOVA}[F(3,2048)$ $=360.741, \mathrm{p}<0.0001]$. Tukey's HSD multiple comparisons test resulted in all groups being significantly different from each other (Table 6). 
All correlations for total width and earlywood raw chronology combinations were $>0.97$ (Table 7). Latewood chronology correlations were poor across the entire matrix. The lowest correlations were between the Velmex and WinDENDRO $(r=0.057)$ and Technician 1 and Technician $2(r=0.317)$ latewood chronologies. A visual analysis of the latewood raw ringwidth chronologies showed two major findings (Fig. 3). First, WinDENDRO latewood measurements were larger than Velmex latewood measurements. Second, technicians had different definitions for the EW-LW boundary with Technician 1 measuring larger latewood widths than Technician 2 regardless of technique. The difference between techniques is a result of the standardized definition of the EW-LW boundary in WinDENDRO. Anecdotal accounts from each technician revealed that Technician 1 manipulated the EW-LW boundary less often in WinDENDRO than Technician 2, explaining the pairing of WinDENDRO and Technician 1 measurements and Velmex and Technician 2 measurements in Figure 3 but not the correlation between these pairs (Table 7).

\section{Discussion}

\section{Crossdating}

We found small differences between methods of crossdating for total- and earlywoodwidth measurements as evidenced by the COFECHA output tables and correlations between standard chronologies and PDSI. However, the discrepancies that do exist between crossdating techniques represent genuine errors in dating most often occurring in the WinDENDRO system. The majority of misdated series were caused by the inability of technicians to accurately identify false rings in the 3200 dpi scanned images of increment cores. In the study, technicians were allowed to verify boundaries under a microscope when necessary; however, the absence of "A" 
flags in COFECHA on the misdated segments led the technicians to believe the series were crossdated correctly. The absence of "A" flags was caused by dating errors that occurred early in the first 50-year segment in most cases and resulted in similar correlations for the remainder of segments in the series.

The misdated series not flagged in COFECHA point towards a larger trade-off between the speed and accuracy of crossdating. While we did not collect data on the amount of time spent measuring and crossdating each core because of the confounding effect caused by technician experience with the wood, a qualitative discussion of time requirements and crossdating accuracy is warranted. Skeleton-plotting and pattern matching against a master chronology is time-consuming. Then, a technician must measure individual rings using a Velmex system to be able to check the accuracy of crossdating in COFECHA. Corrections suggested by COFECHA may require re-measurement and changes must be made to the measurement file in a separate program. WinDENDRO can be used to condense the pattern matching and measurement steps into one iterative routine. Because measurements of a tree-ring series are compared to a digital master in real time, the effect of manipulations to the measurement series (e.g., inserting a micro-ring) can be seen immediately and the new measurements saved. Shifts suggested by COFECHA can be addressed instantly and new measurement files can be exported from WinDENDRO. Thus, it appears that WinDENDRO is a faster system for measurement and crossdating.

The trade-off between the speed and accuracy of crossdating in WinDENDRO occurs when misdated series are not detected and not flagged in COFECHA despite the presence of false rings. Additionally, technicians disregarded some valid flags caused by undetected false rings and finalized crossdating believing shifts suggested by COFECHA to be inaccurate. Shifts 
that were made in WinDENDRO were confirmed by examining cores under a stereoscope requiring additional time. In the comparison of COFECHA output tables, the greater number of flags in the WinDENDRO technique represents the known costs of the increased speed of measurement and crossdating. However, the true errors are undetected without further investigation. In our study, 7 of the 40 total series were not accurately crossdated in WinDENDRO, violating the key principle of dendrochronology.

In the correlation function analysis, total width and earlywood performed as expected with significant positive correlations with growing season PDSI, confirming results of previous research with eastern redcedar (Hawley 1937; Guyette et al. 1980). It must be noted that we did not examine correlations with previous year PDSI, and eastern redcedar earlywood widths may not have correlated well with current year PDSI if they did not comprise $92 \%$ of the annual growth.

Significant differences between eastern redcedar latewood chronologies preclude the use of latewood chronologies for climatic analysis. This recommendation is supported by: 1) the discrepancy over the earlywood-latewood boundary; 2) the lack of consistency in correlations across methods and technicians; and 3) the small variability in eastern redcedar latewood widths. However, latewood widths in other species have been successfully used in dendroclimatic analysis. For example, Meko and Baisan (2001) utilized a network of five latewood width chronologies of Douglas fir (Pseudotsuga menziesii Mirb.) collected in Arizona, USA to better understand the variability of summer rainfall in the North American Monsoon. Earlywoodlatewood boundaries were visually identified under a microscope and spot checks revealed that boundaries were repeatable across technicians. The authors found that latewood width was an 
effective predictor of dry summers using a binary recursive classification tree model but cautioned that identification of boundaries could be made less subjective.

\section{Measurements}

Results from Verify for Windows and the ANOVA of the raw total- and earlywood-width chronologies reveal little difference between measurements, suggesting that series measured using different techniques can be combined for further dendrochronological analysis after questionable boundaries in WinDENDRO have been scrutinized under a stereoscope. Differences between total- and earlywood-width measurement series pairs were caused mostly by misdating rather than errors in measurement. Measurements of latewood width were more difficult to interpret. Measurements of the same core appeared similar between techniques because of the limited variability of latewood widths. However, the ANOVA and the correlation matrix using latewood widths showed that the four chronology groups were all significantly different from each other, indicating a lack of accuracy across techniques and technicians.

Our definition of the EW-LW boundary in WinDENDRO and the adjustment of the boundary in both the WinDENDRO and Velmex systems were the likely cause of raw latewood chronology differences between techniques. The difference in latewood measurements between techniques highlights the importance of a standard definition of the EW-LW boundary for all technicians. Mork (1928) proposed a definition of latewood based on the formula:

$$
\mathrm{LW}=2 \times \text { Double } \mathrm{CW} \geq \mathrm{CL},
$$

where $\mathrm{LW}$ is a latewood tracheid, Double $\mathrm{CW}$ is the joint wall between two cells, and CL is the lumen diameter (Denne 1988). Mork's definition has been applied in high-magnification (50x or more) image analysis investigations of tree rings with success (e.g., Camarero et al. 1998; e.g., Park \& Spiecker 2005) but the technique is time intensive and not suitable for large sample sizes. 
Additionally, the analysis of tree-ring images requires specialized software to measure individual cell components. In X-ray densitometry of tree rings, the transition from earlywood to latewood can be defined objectively by: 1) setting a density threshold within an annual ring (Cleaveland 1986; Schweingruber et al. 1978); 2) formulas utilizing minimum and maximum ring density measurements (Polge 1978); or 3) other mathematical approaches (Koubaa et al. 2002). The density threshold is most commonly used in laboratories equipped with X-ray facilities.

A standard definition of the EW-LW boundary is necessarily different depending on the technique of measurement in our study because boundaries may not be easily defined under a stereoscope and individual cells are not visible in 3200 dpi images (Fig. 2). In the Velmex technique, a general definition of thickening of cells walls may be used to define the boundary but the boundary will still remain subjective between technicians with common 50x stereoscopes. Similar to setting the density threshold in X-ray densitometry, the light intensity threshold in WinDENDRO can be determined for each species and site based on a sampling of annual ring measurements, thereby reducing technician bias. Yet, light intensity and density thresholds suffer from the same problem of incorrectly defining EW-LW boundaries in some rings with low-light intensity or density. A fixed definition is appealing because it can be consistently applied across increment cores despite requiring adjustment for annual rings with growth anomalies or cracks in the wood. In our study, the latewood measurement differences between technicians were an effect of the manipulation of the EW-LW boundary in WinDENDRO by each technician. If individual cells were visible in WinDENDRO, a clear definition may be achievable across crossdating techniques. Until a standard definition of the EW-LW boundary can be created across platforms, we do not recommend combining latewood width series from different systems and possibly from different technicians. 


\section{Conclusion}

We recognize that eastern redcedar is a difficult species to crossdate, regardless of technique, because of the prevalence of false, missing, and micro-rings. We could have experimented further with the EW-LW boundary definition in the WinDENDRO system to aid technicians in the measurement process. Additionally, a set of well-defined rules for the amount of allowable boundary manipulation could be developed in future work. Based on our analysis, total-width measurements of eastern redcedar are acceptable to combine across measurement and crossdating systems even for species with narrow, false, or micro-rings. However, WinDENDRO measurements (and crossdating) are only acceptable if questionable annual rings are verified with a stereoscope. The use of latewood widths across techniques and technicians for eastern redcedar resulted in significant differences in correlations with climate variables, suggesting that latewood widths are not suitable for further dendroclimatic analysis.

For species with common growth anomalies and narrow rings, the Velmex system is preferable because individual cells can be seen clearly under magnification. Perhaps, future computing and imaging technologies will allow individual cells to be visible in WinDENDRO without the interpolation of scanned images and the burden of large file sizes slowing image manipulation. Image size and dpi will become less of a limitation as imaging and computing technology progresses. In the future, we suggest the development of a rigorous standardized definition for the EW-LW boundary in both measurement and crossdating systems.

\section{Acknowledgements}

This research was funded in part by the NASA WV Space Grant Consortium, West Virginia University Eberly College of Arts and Sciences, and National Science Foundation 
Doctoral Dissertation Research Grant \#0925114. We would like to thank Peter Clark and

Thomas Saladyga for their thoughtful comments on the manuscript.

\section{References}

Brown, P.M., 1996. OLDLIST: A database of maximum tree ages. In J. Dean, D. Meko, \& T. Swetnam, eds. Tree Rings, Environment, and Humanity. Radiocarbon 1996. Tuscon, Arizona: Department of Geosciences, pp. 727-731.

Camarero, J., Guerrero-Campo, J. \& Gutierrrez, E., 1998. Tree-ring growth and structure of Pinus uncinata and Pinus sylvestris in the Central Spanish Pyrenees. Arctic and Alpine Research, 30, 1-10.

Cleaveland, M., 1986. Climatic response of densitometric properties in semiarid site tree rings. Tree-Ring Bulletin, 46, 13-47.

Cook, E.R., 1985. A time series analysis approach to tree-ring standardization. Ph.D. Dissertation, University of Arizona, Tuscon. $171 \mathrm{p}$.

Cook, E. \& Kairiukstis, L., 1990. Methods of Dendrochronology: Applications in the Environmental Science, Kluwer Academic Publishers.

Denne, M., 1988. Definition of latewood according to Mork. IAWA Bulletin, 10, 59-62.

Fritts, H., 1976. Tree Rings and Climate, New York, NY: Academic Press.

Gedalof, Z. \& Smith, D., 2001. Dendroclimatic response of mountain hemlock (Tsuga mertensiana) in Pacific North America. Canadian Journal of Forest Research, 31, 322332.

Grissino-Mayer, H., 2001. Evaluating crossdating accuracy: a manual and tutorial for the computer program COFECHA. Tree-Ring Research, 57, 205-221.

Guyette, R. et al., 1980. A climate history of Boone County, Missouri from tree-ring analysis of eastern redcedar. Wood and Fiber, 12, 17-28.

Hawley, F., 1937. Relationship of southern cedar growth to precipitation and run off. Ecology, $18,398-405$.

Holmes, R.L., 1983. Computer assisted quality control in tree-ring dating and measurement. Tree-Ring Bulletin, 43, 69-78.

International Tree-Ring Data Bank, 2010. ICBP PAGES/World Data Center for Paleoclimatology, NOAA/NCDC Paleoclimatology Program, Boulder, Colorado, USA. 
Koubaa, A., Zhang, S. \& Makni, S., 2002. Defining the transition from earlywood to latewood in black spruce based on intra-ring wood density profiles from X-ray densitometry. Annals of Forest Science, 59, 511-518.

Laroque, C. \& Smith, D., 1999. Tree-ring analysis of yellow-cedar (Chamaecyparis nootkatensis) on Vancouver Island, British Columbia. Canadian Journal of Forest Research, 29(1), 115-123.

Larson, D., 1997. Dendroecological potential of Juniperus virginiana L. growing on cliffs in western Virginia. Banisteria, 10, 13-18.

Lawrence, D. \& Grissino-Mayer, H., 2001. Verify for Windows.

Meko, D.M. \& Baisan, C.H., 2001. Pilot study of latewood-width of conifers as an indicator of variability of summer rainfall in the North American Monsoon Region. International Journal of Climatology, 21, 697-708.

Mork, E., 1928. Die Qualitat des Fichtenholzes unter besonderer Rucksichtnahme auf Schleifund Papierholz. Der Papier Fabrikant, 26, 741-747.

National Oceanic and Atmospheric Administration, 2009. West Virginia Climate Region Six. National Climatic Data Center. Asheville, NC.

Palmer, W., 1965. Meterological Drought. Research Paper No. 45., United States Weather Bureau. 64p.

Park, Y. \& Spiecker, H., 2005. Variations in the tree-ring structure of Norway Spruce (Picea abies) under contrasting climates. Dendrochronologia, 23, 93-104.

Polge, H., 1978. Fifteen years of wood radiation densitometry. Wood Science Technology, 12, 187-196.

Regent Instruments Canada Inc., 2009. WINDENDRO for tree-ring analysis.

Schweingruber, F. et al., 1978. The x-ray technique as applied to dendroclimatology. Tree-Ring Bulletin, 38, 61-91.

Sites, R., 1973. Geology of Smoke Hole region in Grant and Pendleton Counties, West Virginia. Masters thesis., West Virginia University, Morgantown.

Speer, J.H., 2010. Fundamentals of Tree Ring Research, Tucson, AZ: University of Arizona Press.

Stokes, M. \& Smiley, T., 1968. An introduction to tree-ring dating, Tucson, AZ: University of Arizona Press. 
Vaganov, E., Hughes, M. \& Shashkin, A., 2006. Growth Dynamics of Conifer Tree Rings: Images of Past and Future Environments, Berlin: Springer-Verlag.

Velmex Inc., 2009. Velmex Measurement System.

Voor Tech Consulting, 2008. Measure J2X. 


\section{Tables}

Table 1. Study design.

\begin{tabular}{llll} 
& & \multicolumn{2}{c}{ Crossdating Method } \\
\cline { 2 - 4 } Technician & Velmex & WinDENDRO \\
\cline { 2 - 4 } & Technician 1 & Cores 1-20 & Cores 21-40 \\
\cline { 2 - 4 } & Technician 2 & Cores 21-40 & Cores 1-20 \\
\cline { 2 - 4 } & &
\end{tabular}

Table 2. Chronology testing groups. Tech $1=$ Technician $1 ;$ Tech $2=$ Technician 2 .

\begin{tabular}{llll} 
Velmex & WinDENDRO & Technician 1 & Technician 2 \\
\hline Cores 1-20: Tech 1 & Cores 1-20: Tech 2 & Cores 1-40: & Cores 1-40: \\
and & and & Velmex and & Velmex and \\
Cores 21-40: Tech 2 & Cores 21-40: Tech 1 & WinDENDRO & WinDENDRO \\
\hline
\end{tabular}

Table 3. COFECHA results from crossdating groups. Series rejected in the verification analysis in Verify for Windows are in the last row. For further explanation of COFECHA results, please consult Grissino-Mayer (1996). VM = Velmex; WD = WinDENDRO; Tech $1=$ Technician 1;

Tech 2 = Technician 2 .

Cores 1-20

\begin{tabular}{lcc|cc} 
& VM (Tech1) & WD (Tech 2) & VM (Tech 2) & WD (Tech 1) \\
\hline Dated Series & 20 & 20 & 20 & 20 \\
Series Dates & $1495-2007$ & $1495-2007$ & $1542-2007$ & $1542-2007$ \\
Master Series Length & 513 & 513 & 466 & 466 \\
Series Intercorrelation & 0.549 & 0.528 & 0.607 & 0.615 \\
Average Mean Sensitivity & 0.287 & 0.291 & 0.315 & 0.315 \\
Flagged Segments & 15 & 25 & 11 & 10 \\
Mean Length of Series & 243.9 & 243.3 & 295.8 & 295.4 \\
Misdated Series & 0 & 6 & 4 & 1 \\
Series Rejected in Verify & 0 & 4 & 3 & 1 \\
\hline
\end{tabular}


Table 4. Chronology correlations with Palmer Drought Severity Index. Bolded values are significant $(\mathrm{p}<0.10) . \mathrm{VM}=$ Velmex; $\mathrm{WD}=$ WinDENDRO; Tech $1=$ Technician 1 ; Tech $2=$ Technician 2 .

\begin{tabular}{|c|c|c|c|c|c|c|c|c|c|c|c|c|}
\hline & \multicolumn{4}{|c|}{ Total Width } & \multicolumn{4}{|c|}{ Earlywood } & \multicolumn{4}{|c|}{ Latewood } \\
\hline & VM & $\overline{\text { WD }}$ & $\overline{\text { Tech } 1}$ & Tech 2 & VM & WD & $\overline{\text { Tech } 1}$ & Tech 2 & VM & WD & $\overline{\text { Tech } 1}$ & Tech 2 \\
\hline Jan & 0.049 & 0.046 & 0.044 & 0.051 & 0.052 & 0.043 & 0.045 & 0.048 & -0.017 & 0.153 & 0.061 & 0.084 \\
\hline Feb & 0.071 & 0.069 & 0.067 & 0.072 & 0.073 & 0.065 & 0.070 & 0.068 & 0.022 & 0.199 & 0.041 & 0.174 \\
\hline Mar & 0.169 & 0.172 & 0.168 & 0.174 & 0.171 & 0.169 & 0.169 & 0.170 & 0.111 & 0.266 & 0.109 & 0.263 \\
\hline Apr & 0.149 & 0.151 & 0.148 & 0.154 & 0.151 & 0.148 & 0.149 & 0.151 & 0.123 & 0.221 & 0.089 & 0.246 \\
\hline May & 0.293 & 0.298 & 0.293 & 0.299 & 0.298 & 0.295 & 0.295 & 0.298 & 0.094 & 0.335 & 0.161 & 0.266 \\
\hline Jun & 0.319 & 0.321 & 0.319 & 0.322 & 0.322 & 0.319 & 0.321 & 0.320 & 0.106 & 0.263 & 0.132 & 0.227 \\
\hline Jul & 0.248 & 0.254 & 0.248 & 0.254 & 0.250 & 0.253 & 0.250 & 0.252 & 0.097 & 0.216 & 0.121 & 0.179 \\
\hline Aug & 0.178 & 0.181 & 0.176 & 0.182 & 0.180 & 0.179 & 0.179 & 0.179 & 0.059 & 0.254 & 0.143 & 0.172 \\
\hline Sep & 0.114 & 0.116 & 0.109 & 0.119 & 0.117 & 0.114 & 0.110 & 0.119 & 0.018 & 0.178 & 0.103 & 0.086 \\
\hline Oct & 0.079 & 0.073 & 0.073 & 0.078 & 0.082 & 0.073 & 0.073 & 0.081 & -0.044 & 0.142 & 0.109 & -0.009 \\
\hline Nov & 0.094 & 0.084 & 0.086 & 0.089 & 0.095 & 0.084 & 0.086 & 0.091 & 0.008 & 0.148 & 0.108 & 0.043 \\
\hline Dec & 0.096 & 0.082 & 0.085 & 0.091 & 0.096 & 0.081 & 0.084 & 0.092 & 0.072 & 0.139 & 0.112 & 0.092 \\
\hline Ann & 0.196 & 0.195 & 0.191 & 0.199 & 0.199 & 0.192 & 0.193 & 0.197 & 0.067 & 0.270 & 0.140 & 0.192 \\
\hline
\end{tabular}

Table 5. Selected Verify for Windows results. Standard deviations in parentheses. Verification of measurements with the $0.01 \mathrm{~mm}$ mean squared difference acceptance threshold level.

\begin{tabular}{ccccccc} 
Series & $\begin{array}{c}\text { Average } \\
\text { Mean } \\
\text { Growth } \\
(\mathbf{m m})\end{array}$ & $\begin{array}{c}\text { Mean } \\
\text { Correlation }\end{array}$ & $\begin{array}{c}\text { Average } \\
\text { Mean } \\
\text { Diff. }(\mathbf{m m})\end{array}$ & $\begin{array}{c}\text { Average } \\
\text { Mean } \\
\text { Squared } \\
\text { Diff. }(\mathbf{m m})\end{array}$ & $\begin{array}{c}\text { \# Reject/ } \\
\text { \# Accept }\end{array}$ & $\begin{array}{c}\text { \# } \\
\text { Outliers }\end{array}$ \\
\hline Total Width & 0.501 & 0.959 & 0.035 & 0.011 & & \\
Earlywood & $(0.199)$ & $(0.057)$ & $(0.021)$ & $(0.022)$ & $8 / 32$ & 803 \\
Latewood & 0.461 & 0.958 & 0.037 & 0.011 & $7 / 33$ & 696 \\
& $(0.199)$ & $(0.060)$ & $(0.021)$ & $(0.022)$ & & \\
& 0.040 & 0.224 & 0.015 & 0.000 & $0 / 40$ & 351 \\
\hline
\end{tabular}


Table 6. Tukey's HSD multiple comparisons test of latewood chronologies. Groups with different letters are significantly different $(\mathrm{p}<0.05)$ from other groups.

\begin{tabular}{lccccc} 
Chronology & Least Squares Means & & \multicolumn{2}{c}{ Groups } \\
\hline WinDENDRO & 0.044 & A & & & \\
Technician 2 & 0.043 & & B & & \\
Technician 1 & 0.037 & & & C & \\
Velmex & 0.035 & & & & D \\
\hline
\end{tabular}

Table 7. Raw ring width chronology correlation matrix. $\mathrm{VM}=$ Velmex; $\mathrm{WD}=\mathrm{WinDENDRO}$;

Tech 1 = Technician 1; Tech 2 = Technician 2 .

Total Width $\quad \underline{\text { Earlywood }}$ Latewood

\begin{tabular}{lcccc|cccc|cccc} 
& VM & WD & Tech 1 & Tech 2 & VM & WD & Tech 1 & Tech 2 & VM & WD & Tech 1 & Tech 2 \\
\hline VM & 1.000 & & & & 1.000 & & & & 1.000 & & & \\
WD & 0.977 & 1.000 & & & 0.968 & 1.000 & & & 0.057 & 1.000 & & \\
Tech 1 & 0.979 & 0.996 & 1.000 & & 0.980 & 0.990 & 1.000 & & 0.632 & 0.405 & 1.000 & \\
Tech 2 & 0.996 & 0.979 & 0.975 & 1.000 & 0.989 & 0.979 & 0.970 & 1.000 & 0.653 & 0.516 & 0.317 & 1.000 \\
\hline
\end{tabular}




\section{Figure Captions}

Fig. 1. Location of sampling site.

Fig. 2. Images of the same eastern redcedar core: a) scanned at 3200 dpi on an Epson Expression 10000XL scanner with $150 \%$ digital zoom on the image; and b) 50x magnification photo from a SPOT Insight camera attached to a Leica stereoscope. Original images have been resized for publication. Growth is from left to right. The arrows point to a false ring in 1596 AD. Notice that individual cells are not visible in the scanned image (a).

Fig. 3. Total width (a), earlywood (b), and latewood (c) raw chronologies for Velmex, WinDENDRO, Technician 1, and Technician 2 chronology testing groups. 
Figures

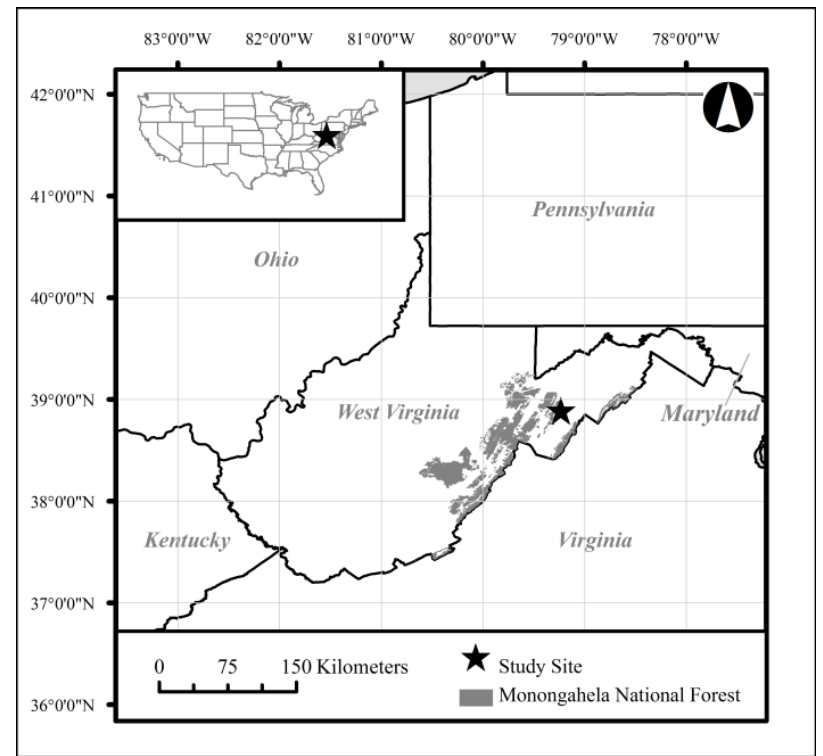

Figure 1 


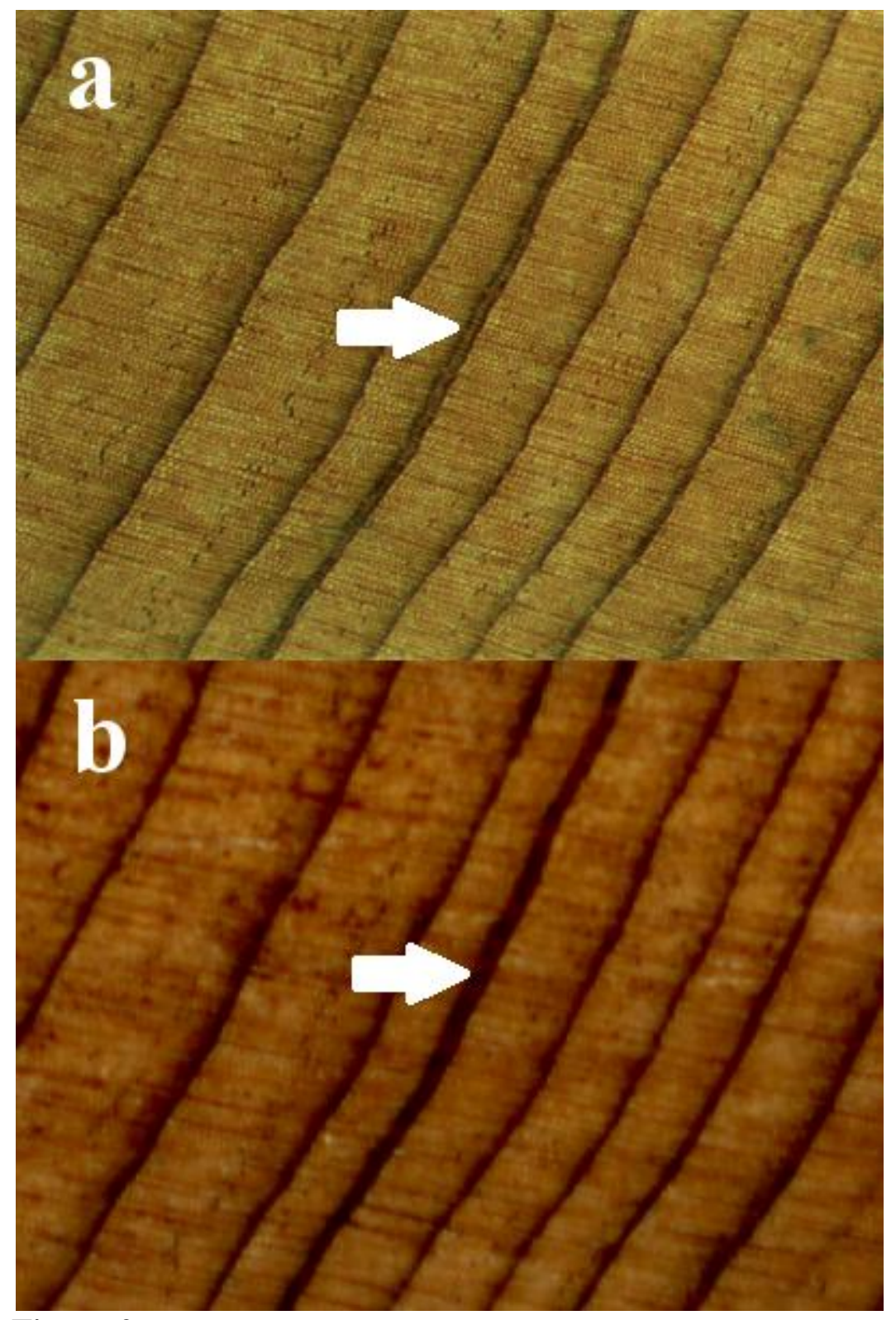

Figure 2 
a) Raw Total Ring Width Chronologies

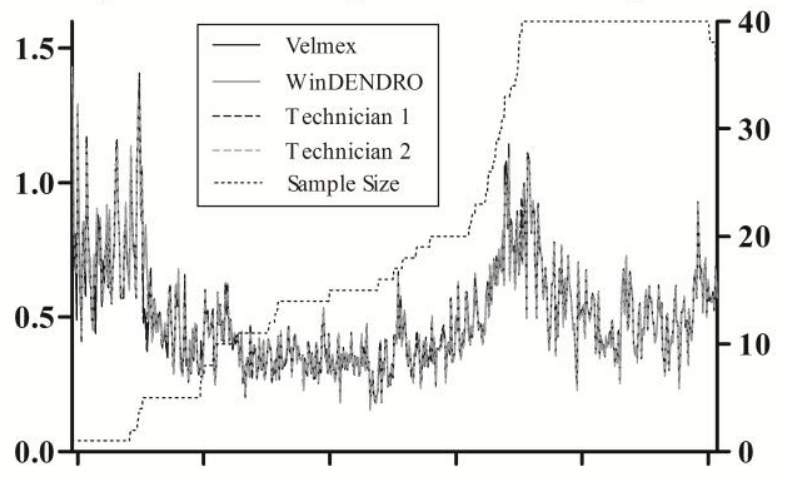

b) Raw Earlywood Width Chronologies

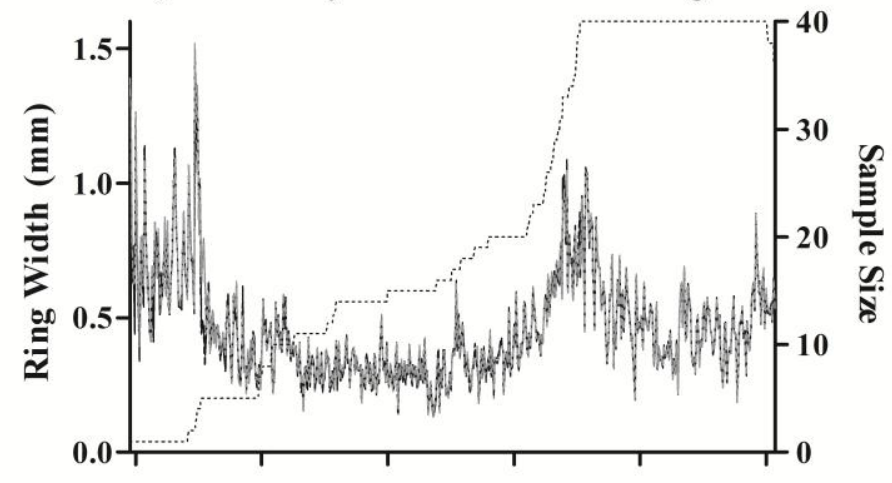

c) Raw Latewood Width Chronologies

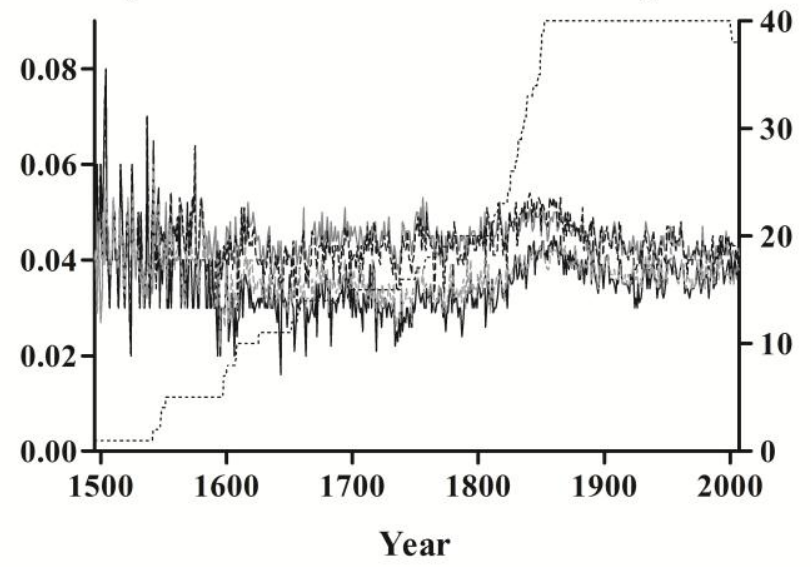

Figure 3 


\section{Chapter 2: A 1248-year reconstruction of May precipitation for the Mid-Atlantic Region using Juniperus virginiana tree rings}

*R. Stockton Maxwell and Amy E. Hessl

West Virginia University

Department of Geology and Geography

Morgantown, $W V$

Edward R. Cook

Tree-Ring Laboratory

Lamont-Doherty Earth Observatory

Pallisades, $N Y$

To be submitted to the Journal of Climate

\footnotetext{
*Corresponding author address: R. Stockton Maxwell, West Virginia University, Department of Geology and Geography, P.O. Box 6300, Morgantown, WV 26506-6300

Email: stockton.maxwell@gmail.com
} 


\begin{abstract}
We present a 1248-year reconstruction of May precipitation (AD 750-1998) for the MidAtlantic Region of the United States. The reconstruction is based on the first principal component (PC1) of two millennial-length eastern redcedar (Juniperus virginiana) tree-ring chronologies collected from rocky, limestone sites in the Ridge and Valley province of West Virginia. A split-calibration linear regression model accounted for $32 \%$ of the variance in the instrumental record and was stable through time. The model was well verified by the reduction of error $(\mathrm{RE}=0.33)$ and coefficient of efficiency $(\mathrm{CE}=0.30)$ statistics. Centennial-length changes in precipitation were rare but wetter than median conditions and drier than median conditions occurred during the Medieval Warm Epoch (AD 1000-1300) and the Little Ice Age (AD 1450-1850), respectively. The full reconstruction contained substantial inter-annual and decadal variability, however, the $19^{\text {th }}$ and $20^{\text {th }}$ centuries recorded the greatest number of annual and decadal extreme wet and dry periods. A comparison of the May precipitation reconstruction to other regional reconstructions of July Palmer Hydrologic Drought Index and Chesapeake Bay salinity showed that not only did drought and pluvial events extend into the Ridge and Valley province but they also began early in the growing season. A positive correlation between PC1 and the winter North Atlantic Oscillation Index indicates that eastern redcedar's response to May precipitation is mediated by winter temperature.
\end{abstract}




\section{Introduction}

The Mid-Atlantic Region (MAR) of the United States is home to 15\% (35.2 million) of the country's population, with about two-thirds of that population living in urban areas (e.g., Philadelphia, Washington, D.C.) near the coast or large rivers (Polsky et al. 2000). While water resources in the region are generally abundant, periodic drought and pluvial events require careful management of water resources and the surrounding watersheds to minimize the negative impact of changes in water quantity and quality (Neff et al. 2000; Najjar et al. 2000). Water managers face additional challenges because the MAR is predicted to become warmer and wetter in the coming decades (Polsky et al. 2000). The expected changes in climate and hydrology, in combination with a projected increase in population, will place greater demand on the region's water resources and impact ecosystem services from the region's forests, wetlands, and freshwater and coastal ecosystems (McKenney-Easterling et al. 2000; Najjar et al. 2000; Rogers and McCarty 2000). Increases in precipitation, seasonal streamflow, and a shift to earlier streamflow peaks in the winter and spring are projected (Neff et al. 2000) but it is not known if these changes are within the natural range of variability for the region. Currently, water resource managers in the MAR rely on instrumental records of precipitation and streamflow ( $<120$ years) that are not adequate to assess variability in water quantity within the context of past centuries. Therefore, information on past variability in spring precipitation may be used to better prepare for future changes in water quantity and quality.

The development of tree-ring reconstructions of precipitation, drought, snowfall, and streamflow is well established and reconstructions are commonly used to evaluate changes in water resources over the centuries (Stockton and Jacoby 1976; Graumlich 1987; Stahle and Cleaveland 1992; Pederson et al. 2001; Meko et al. 2001; Woodhouse 2003). However, 
annually-resolved millennial-length proxy records of hydroclimate are rare in eastern North America because suitable sources of high-resolution natural archives (i.e., old-growth tree species) have been destroyed by human land alteration or are limited by tree species biology. An emerging source of climate history for the MAR is eastern redcedar (Juniperus virginiana L.) growing on moisture-limited limestone sites near the headwaters of the Potomac River. Hawley (1937) was the first to publish on the utility of long-lived (500+ years), climate-sensitive eastern redcedar trees growing in eastern Tennessee. In her work, Hawley found a positive correlation $(r$ $=0.69$ ) between annual growth and water-year precipitation. Guyette et al. (1980) further investigated the potential of using eastern redcedar annual growth for reconstructing climate in Missouri. The authors found positive correlations between ring-width index and growing season precipitation $(r=0.48)$ and a negative correlation with early growing season temperature $(r=-$ 0.54). In southwest Virginia, Larson (1997) positively correlated eastern redcedar annual increment with total May-July precipitation $(r=0.56)$, stating that the species increases in growth during cool and wet springs. Recently, Maxwell et al. (in review) showed that long-lived eastern redcedar trees growing on limestone sites in West Virginia were responsive to late-spring and summer Palmer Drought Severity Index ( $r=0.29$ to 0.32 ; PDSI). Eastern redcedar trees sampled for the studies described above were all sampled on similar cliff, bluff, knob, or barren sites throughout the eastern United States that are: 1) primarily limestone-based with poor soil development; 2) south to south-west facing; 3) steep-sloped; 4) sparsely populated by other trees and understory vegetation; and 5) mostly undisturbed by fire, logging, and grazing. The previous research suggests that eastern redcedar is well suited for reconstruction of climate variables because it is long-lived and sensitive to variations in temperature and precipitation. Because eastern redcedar is the most widely distributed conifer in the eastern United States 
(Lawson 1990), additional dendroclimatic sites likely exist where limestone is the primary component of the soil and trees remain undisturbed.

In this paper, we present two millennial-length chronologies developed from sub-fossil wood and long-lived eastern redcedar (Juniperus virginiana L.) trees growing on moisturelimited sites in the Ridge and Valley physiographic province of West Virginia. The first chronology was developed explicitly for this study. The second chronology (Cedar Knob) was used previously as a predictor chronology in Cook et al.'s (1999) reconstruction of PDSI for the continental United States and Cook et al.'s (2002) multi-proxy reconstruction of the winter North Atlantic Oscillation Index (NAO), but has not been investigated as a predictor in a single-species reconstruction for the MAR. We examine both chronologies' dendroclimatic response to regional temperature and precipitation, reconstruct May precipitation from AD 750-1998, and evaluate the temporal variation in the reconstruction for annual to centennial pluvial and drought events. We compare the reconstruction to two other regional records, Stahle et al.'s (1998) July Palmer Hydrologic Drought Index (PHDI) reconstruction and Cronin et al.'s (2000) Chesapeake Bay salinity reconstruction. Finally, we discuss seasonal teleconnections in the MAR and factors mitigating eastern redcedar's dendroclimatic response.

\section{Data}

\section{a. Tree-ring data}

Increment cores from live eastern redcedar trees and cross sections from sub-fossil wood were collected from two moisture-limited locations (i.e., Smoke Hole Canyon and Cedar Knob) in the Ridge and Valley province of West Virginia. Sample locations were previously identified as cedar or limestone glades by Bartgis (1993) and are characterized by shallow, rocky soils with 
sparse annual and perennial understory vegetation. Sampling in Smoke Hole Canyon (3853'02" N 79¹4'12" W; Fig. 1) occurred in AD 2006 and 2007 at three locations with similar site conditions. All locations are $\sim 650 \mathrm{~m}$ asl, south-west facing, and moderate to steep in slope $\left(>25^{\circ}\right)$. Tree-ring samples were returned to the lab and prepared and crossdated using standard dendrochronological techniques (Fritts 1976; Cook and Kairiukstis 1990). While several hundred increment cores and cross sections were collected in Smoke Hole, we eliminated live samples $\geq 250$ years old and cross sections $\leq 150$ years old from the chronology to retain lowfrequency signals (Cook et al. 1995). In total, 48 increment cores from 36 live trees and 80 radii from 45 cross sections were used. Samples crossdated well between Smoke Hole locations with a 0.536 series intercorrelation and 0.326 average mean sensitivity (Grissino-Mayer 2001). Because tree growth between sites was well correlated, a Smoke Hole chronology (AD 5172007) was created by merging tree-ring samples from the three collection sites.

Tree-ring data from a second location, Cedar Knob, $20 \mathrm{~km}$ south of Smoke Hole were collected in AD 1998 (38³9'30" N 79²2'45" W; Fig.1) and have been used in previous dendroclimatic research reconstructing a nation-wide PDSI grid (Cook et al. 1999) and winter NAO Index (Cook et al. 2002). The Cedar Knob chronology (AD 481-1998) is a composite of three sites located within $3 \mathrm{~km}$ of each other. All Cedar Knob collection sites share similar slope, aspect, and soil conditions to the Smoke Hole sites but are higher in elevation ( $~ 850 \mathrm{~m}$ asl). Similar to Smoke Hole, hundreds of samples were collected at Cedar Knob but only longer segments were retained (see above). In total, 15 increment cores from 11 live trees and 137 radii from 98 cross sections were used. Samples from the Cedar Knob sites crossdate well across sites with a 0.548 series intercorrelation and 0.313 average mean sensitivity. 
Individual raw ring-width series from the two sample locations were standardized in ARSTAN with a 300-year smoothing spline (50\% frequency response cut-off) to remove biological growth trends and preserve annual- to centennial-scale climate signals (Cook 1985). Low-order autocorrelation was removed from each series with an autoregressive moving average model. Then, individual series were averaged together to create residual chronologies for each location (Fig. 2). The variance of the residual time series was stabilized using the Briffa RBARweighted method to account for changes in variance due to the reduction in sample size backward in time (Osborn et al. 1997). The expressed population signal (EPS) was calculated for each chronology using 50-year segments overlapped 25 years. The EPS is a measure of the common variance in a chronology and weakens as sample size decreases (Briffa 1984; Wigley et al. 1984). While no rule exists for use of the EPS, Wigley et al. (1984) suggested that chronologies could be truncated when the EPS drops below $85 \%$. We chose to restrict our analyses when the average EPS for the two chronologies dropped below $85 \%$ and did not rebound.

The Smoke Hole and Cedar Knob residual chronologies are correlated well with each other $(r=0.85)$ and an initial correlation function analysis between individual chronologies and regional climate data showed similar responses to monthly temperature and precipitation (data not shown). Therefore, we elected to use a principal components analysis (PCA) to combine the chronologies into a single predictor variable. PCA is widely used in dendroclimatic analysis to reduce the number of predictor chronologies and detect structure between variables (Briffa 1995; Cook and Kairiukstis 1990). Our primary concern was to reduce the collinearity between predictor chronologies and create a linear combination of the original variables that maintained the greatest possible variance in the tree-ring data. The PCA of the residual chronologies 
resulted in one principal component (PC) with an eigenvalue $>1$ (Kaiser-Guttman rule) that explained $81 \%$ of the variance in the predictors (Guttman 1954; Kaiser 1960). For subsequent dendroclimatic analyses, we used the first principal component (PC1) as the primary predictor variable.

\section{b. Climate data}

Monthly precipitation and temperature data (1895-1998) were obtained from the National Climatic Data Center for West Virginia Climate Region 6 (National Oceanic and Atmospheric Administration 2009). Region 6 includes the portion of West Virginia in the Ridge and Valley physiographic province and drains into the Chesapeake Bay. The majority of the region lies within the rainshadow of the Appalachian Mountains, receiving $<90 \mathrm{~cm}$ of precipitation annually. While the region does not have defined wet and dry seasons, precipitation peaks in summer months $($ mean $=92.35 \mathrm{~mm})$ with a corresponding peak in temperature $\left(\right.$ mean $\left.=21.8{ }^{\circ} \mathrm{C}\right)$. Precipitation and temperature both reach their seasonal minima during the winter months, averaging $59.4 \mathrm{~mm}$ and $2.2^{\circ} \mathrm{C}$, respectively.

The climate of the MAR is influenced by three large-scale circulation patterns emanating from the continental land mass to the west, the polar region to the north, and the Atlantic Ocean to the east (Barry and Chorley 2003). In the spring, temperature in the eastern portion of West Virginia is controlled largely by the northward movement of the polar jet stream rather than the maritime circulation patterns coming off the Atlantic Ocean. Spring precipitation, however, is influenced by moisture from the Gulf of Mexico and the Atlantic Ocean, and less so by continental systems. Due to the orographic effect of the Appalachian Mountains, much of the Ridge and Valley province lies within a rainshadow and receives less precipitation than coastal areas (National Oceanic and Atmospheric Administration 2009). The North Atlantic Oscillation 
(NAO) is the most prominent and recurrent pattern of atmospheric variability in the Northern Hemisphere (Hurrell et al. 2003), and may affect temperature and precipitation in the MAR but this relationship has not been studied explicitly. The NAO index is defined by the seesaw of atmospheric mass between the Icelandic Low (northern pole) and the Azores High (southern pole) and is climatologically strongest during the cold season months from November-April (Jones et al. 1997; Cook et al. 2002; Hurrell et al. 2003). In the eastern United States, negative winter NAO results in more frequent outbreaks of cold air temperatures and frozen precipitation in winter, while positive winter NAO contributes to mild, wet weather conditions in winter (Hartley and Keables 1998; Hartley 1999; Hurrell et al. 2003). Additionally, increased precipitation and runoff in eastern North America may have some relationship to NAO but the association has not been well defined (Perreault et al. 1999).

Correlation function analysis between PC1 and monthly climate data was performed in the program DENDROCLIM2002 to identify a suitable time period for a precipitation reconstruction (Biondi 1997; Biondi and Waikul 2004). DENDROCLIM2002 implements bootstrapped (1000x) correlation and response functions to indentify significant climatic signals in tree-ring data using static, evolutionary, and moving intervals. Evolutionary and moving intervals allow the user to test for temporal changes of dendroclimatic relationships. To examine the lag effect of climate on tree growth, the analysis window was extended from May of the previous year to October of the current year.

Annual tree growth of eastern redcedar depends on cool, moist May conditions, mild winter and early spring temperatures, and partly, on previous growing season precipitation (Fig. 3a). The relationship between eastern redcedar tree growth and May precipitation and temperature has been reported previously by Guyette et al. (1980) and Larson (1997). The 
response of eastern redcedar to May climate on our sites likely is a function of microclimate and site conditions. In a physiological study of eastern redcedar growing in old fields in southern Illinois, Ormsbee et al. (1976) found that photosynthesis decreased from the maximum rate when air temperature rose above $20^{\circ} \mathrm{C}$. During clear, dry days, the rocky soils of cedar glades and barrens absorb additional radiation causing an increase in evapotranspiration and a decrease in photosynthesis. Cool, moist May days allow eastern redcedar trees to take advantage of the available moisture prior to runoff or evaporation. Also, warmer winter and early spring temperatures appear beneficial to the annual increment of eastern redcedar on our sites. Eastern redcedar has been shown to photosynthesize in winter and spring months when temperature rises above freezing (Ormsbee et al. 1976). The ability to photosynthesize when mild winter/spring temperatures prevail may allow eastern redcedar to build carbohydrates and take advantage of favorable growing conditions in May. The correlation between PC1 and May precipitation $(r=$ 0.51) was further investigated in DENDROCLIM2002 using a 35-year moving window to assess the strength of the correlation through time (Fig. 3b). While the correlation weakens through the 1950s and 1960s, the relationship remains significant and May precipitation was deemed suitable for reconstruction.

\section{Calibration and verification of the reconstruction model}

May precipitation was examined for normality prior to calibration of the reconstruction model. Visual inspection of the normal quantile plot and a test of goodness-of-fit using the Shapiro-Wilk $W$ test $(W=0.97, \mathrm{p}<0.01)$ revealed that the May precipitation is not adequately modeled by the normal distribution. May precipitation was log-transformed to meet the assumptions of linear regression and predicted values were back-transformed following 
verification of the model and full reconstruction. Additionally, least squares regression was used to assess an apparent increasing trend in the instrumental record of precipitation (Fig. 4). May precipitation in Region 6 has increased $0.23 \mathrm{~mm} /$ year from 1895-1998. The increase in precipitation is consistent with regional trends in observational data and predictive modeling (Polsky et al. 2000).

The instrumental data set was split into two periods (1895-1945 and 1946-1998) to test the quality and stability of the calibration models (Fritts 1976; Cook and Kairiukstis 1990). A stepwise multiple linear regression $(F$ to enter $=0.25 ; F$ to remove $=0.10$ ) was used to predict $\log$ May precipitation with $\mathrm{PC} 1$ and $\mathrm{PC}_{\mathrm{t}+1}$ as the predictors. $\mathrm{PC}_{\mathrm{t}+1}(\mathrm{p}>0.258)$ was removed from the model and PC1 became the sole significant predictor $(\mathrm{p}<0.001)$. The calibration models were verified with two rigorous tests of fit, the reduction of error statistic (RE) and the coefficient of efficiency (CE; Fritts 1976; Cook et al. 1999). The RE ranges from $-\infty$ to +1 . When RE exceeds zero, the calibration model shows greater skill than the mean of the instrumental data from the calibration period. The CE has the same range and calculation except the $\mathrm{CE}$ but relies on the verification period mean as a baseline of predictive skill. The RE and CE statistics verified the models well across the two periods, indicating that the models were not affected by the increasing trend in May precipitation over the last century (Table 1; Fig. 4). Regression coefficients and statistics were similar regardless of the period of calibration. The reconstruction model based on the early calibration period for year $t$ is:

$$
\log \text { May precipitation } t=4.34+0.18 \mathrm{x}_{t}
$$

where $\mathrm{x}_{t}$ is principal component value for a given year. With PC1 as the sole predictor representing the common variance of two millennial-length eastern redcedar chronologies, the model explained $32 \%$ of the variance in the calibration period data (AD 1895-1945). Typical of 
tree-ring proxy records, the calibration model did not replicate the extreme instrumental values well and must be considered a conservative estimate of past precipitation (Fig. 4; Fritts 1976). In comparison to other single-species reconstructions in the eastern United States, our calibration model performed well. Buckley et al. (2004) used ring widths from eastern white cedar (Thuja occidentalis L.) to reconstruct summer precipitation for southern Ontario back to AD 610. Principal components were extracted from seven eastern white cedar chronologies to explain $21 \%$ of the variance in the $20^{\text {th }}$ century (33\% from 1900-1960). Stahle et al. (1988) reconstructed June PDSI (AD 372-1985) for North Carolina from a single bald cypress chronology. The calibration model explained $47 \%$ of the adjusted variance in the instrumental record. A second reconstruction of July PHDI in southeastern Virginia, using two bald cypress chronologies, explained $44 \%$ of the adjusted variance in the calibration period (Stahle et al. 1998). An expanded network of moisture-sensitive eastern redcedar chronologies could be used to improve the reconstruction model for the MAR. Given the widespread distribution of eastern redcedar, additional sampling sites likely exist throughout the eastern United States.

\section{Reconstructed May Precipitation}

The full 1248-year reconstruction (AD 750 to 1998) of May precipitation (backtransformed from log units to $\mathrm{mm}$ ) contained substantial inter-annual and decadal variability (Fig. 5). Abrupt decadal changes from wet to dry or dry to wet appear common throughout the record. One of the most severe transitions from wet to dry conditions happened in the mid-13 ${ }^{\text {th }}$ century, when the $9^{\text {th }}$ wettest decade (AD 1237-1246) transitioned to the $8^{\text {th }}$ driest decade (AD 1252-1261) in the reconstruction (Table 2). The AD 1252-1261 period also is significant because it was the longest period of below average precipitation. Earlier in the reconstruction, 
the $9^{\text {th }}$ century had the wettest (AD 838-849) and driest (AD 868-877) decadal periods in the entire record. Additional periods of extreme wet and dry occurred in the $8^{\text {th }}$ and $10^{\text {th }}$ centuries but severe dry and wet events in the $8^{\text {th }}$ through $10^{\text {th }}$ centuries must be interpreted with caution because of the decrease in sample size and instability of the EPS earlier in the series.

The detection and interpretation of centennial-length trends in the reconstruction was limited because we chose to use residual chronologies that have most of the autocorrelation removed to enhance the year-to-year variability of the model. However, we constructed boxand-whisker plots to investigate the distribution of reconstructed precipitation by century and compared the centennial distributions to the distribution of the entire reconstruction (Fig. 6). We have made a few observations about low-frequency trends. First, large shifts in median precipitation are rare and the reconstructed record shows general stability through time. The stability of the reconstruction may be an effect of the reduction in variance caused by the autoregressive moving average model used during standardization (Cook and Kairiukstis 1990). However, slightly greater than median precipitation occurred in the $12^{\text {th }}$ and $13^{\text {th }}$ centuries coincident with the Medieval Warm Epoch ( AD 1000-1300; MWE). While the centennial distributions were less variable during the MWE, extreme wet and dry events during the 300year period were recorded in the reconstruction (Table 2 ). The $14^{\text {th }}$ century shifted back to the median level of precipitation and increased again in the $15^{\text {th }}$ century prior to the Little Ice Age (LIA). Second, decreased variability in precipitation during the $16^{\text {th }}$ century and below median precipitation in the $16^{\text {th }}, 17^{\text {th }}$, and $18^{\text {th }}$ centuries occurred during the period of the Little Ice Age ( $\sim$ AD 1450-1850). Also, the presence of a multi-year drought in the late $16^{\text {th }}$ century provided further evidence of the $16^{\text {th }}$ century megadrought reported by Stahle et al. $(2000,2007)$ and Woodhouse and Overpeck (1998). While the drought was not as severe as droughts occurring 
during the instrumental period, our record showed that the megadrought extended earlier into the growing season. Third, variability in precipitation has increased in the past 300 years and was greater than any time since $\sim \mathrm{AD} 1000$. The $19^{\text {th }}$ century was the most variable in the entire reconstruction and had the greatest number of extreme events (Fig. 6; Table 2). Finally, the reconstruction did not replicate the range of values present in the instrumental record of May precipitation (1900-1998), suggesting again that the reconstruction is a conservative estimate of past precipitation.

Ranking of the top 10 driest and wettest single-year and non-overlapping decadal events in the reconstruction showed that the $19^{\text {th }}$ and $20^{\text {th }}$ centuries have had some of the most extreme events in the proxy record (Table 2). The $19^{\text {th }}$ century had two of the driest and five of the wettest single years, and the largest inter-annual change from dry to wet (AD 1896-1897) in the entire reconstruction. Further, the $19^{\text {th }}$ century had the $6^{\text {th }}$ driest and the $5^{\text {th }}$ wettest 10 -year periods. The single driest year in the annual instrumental precipitation record, AD 1930, was the $4^{\text {th }}$ driest single year in the May precipitation reconstruction. While the 1930 event was surpassed in previous centuries, two periods of extreme decadal-length drought (AD 1911-1920 and 1957-1966) and two periods of extreme decadal-length pluvial (AD 1931-1940 and 19891998) made the $20^{\text {th }}$ century unique.

\section{Regional Comparison}

We compared our reconstruction of May precipitation for West Virginia Climate Region 6 against two regional climate reconstructions by Stahle et al. (1998) and Cronin et al. (2000). We chose not to compare our reconstruction to the gridded PDSI reconstruction network (Cook et al. 1999) because the Cedar Knob eastern redcedar chronology and Stahle et al.'s (1998) 
Blackwater and Nottoway River bald cypress chronologies were included as predictors in the PDSI reconstruction model. Prior to AD 1500, the eastern redcedar and bald cypress chronologies represent three of the four chronologies closest to the Mid-Atlantic PDSI grid points (i.e., 246, 247, 255, 256, 262, and 263) and any comparisons to these points would be collinear and redundant.

Stahle et al. (1998) reconstructed July PHDI (AD 1185-1984) for the Tidewater region of southeastern Virginia and northeastern North Carolina using two 800-year-long bald cypress (Taxodium distichum L.) chronologies collected along the Blackwater and Nottoway Rivers (Fig. 1). The PHDI reconstruction was used to link the disappearance of the Roanoke Island Colony and near abandonment of the Jamestown Colony to extreme drought events around the turn of the $16^{\text {th }}$ century. Cronin et al. (2000) used microfossils and pollen stratigraphy from four Chesapeake Bay sediment cores to reconstruct water salinity over the past 500 years (Fig. 1). Salinity oscillations were interpreted as an indication of variability in regional moisture. Thus, high salinity was indicative of reduced fresh-water discharge into the bay and drought events, while low salinity signaled periods of increased fresh-water discharge and pluvial events. An initial correlation analysis between the paleo records showed a weak but significant positive relationship between reconstructed May precipitation and the July PHDI reconstruction $(r=$ 0.21) and a weak but significant negative relationship with the Chesapeake Bay salinity reconstruction $(r=-0.13)$. The weak results of the correlation analysis are not surprising because: 1) the tree-ring reconstructions represent different species and months of the growing season; 2) the salinity record has large dating error prior to the $20^{\text {th }}$ century $\left(62-145\right.$ years via ${ }^{14} \mathrm{C}$ dating); and 3) precipitation is distributed throughout the year in much of the MAR, making a single-month reconstruction inadequate in accounting for all fresh-water discharge into the bay. 
Then, we visually compared the three records of moisture to determine if the extreme periods of wet and dry in the May precipitation reconstruction (Table 2) were replicated across the records. We found that 11 of 12 extreme dry and wet decadal periods in the May precipitation reconstruction were replicated in the July PHDI proxy record from AD 1185-1984 (Fig. 7). Additional annual and decadal periods of similarity are apparent throughout the overlapping time period. Two periods of interest are the "Lost Colony Drought" from AD 15871589 and the "Jamestown Drought" from AD 1606-1612 (Stahle et al. 1998). Both events were present in the May precipitation reconstruction indicating that the droughts were not only regionwide but also began earlier in the growing season than predicted by the bald cypress record. Two single-year droughts in 1587 and 1598 ranked in the top 30 dry events in the May precipitation record. On the centennial timescale, the PHDI reconstruction showed a similar decrease in variance during the $16^{\text {th }}$ century and below median moisture conditions in both the $16^{\text {th }}$ and $17^{\text {th }}$ century that are coincident with the LIA and the $16^{\text {th }}$ century megadrought (Stahle et al. 2007).

The lack of annual resolution and ${ }^{14} \mathrm{C}$ dating error (62-145 years) associated with the Cronin et al. (2000) salinity record made comparisons with our reconstruction more difficult. Seven of nine extreme May precipitation events (Table 2) during the period of overlap (AD 1458-1997) cohered in part with increased and decreased salinity (i.e., drought and pluvial, respectively) despite large alterations to the Chesapeake Bay watershed in the past 150 years. However, other multi-decadal periods appear out of sync with both our and the Stahle et al. treering reconstructions. Most notably, two major drops in salinity (pluvials) in the $16^{\text {th }}$ century occurred during periods of tree-ring reconstructed drought, including the nation-wide megadrought in the late $16^{\text {th }}$ century (Stahle et al. 2007). Dating error in the salinity record may 
account for the periods of disagreement between the proxy records. A second period of multidecadal disagreement occurred during the mid- $18^{\text {th }}$ to early- $19^{\text {th }}$ centuries when a shift to a lowsalinity phase signaled the onset of a prolonged wet period in the MAR (Cronin et al. 2000). The July PHDI reconstruction confirmed the presence of a prolonged wet period with above average PHDI, while our May precipitation reconstruction showed consistently average to below-average moisture during the same time period.

Despite some disagreement between the three regional records, the comparison was valuable because it demonstrated that: 1) decadal to multi-decadal trends in moisture were persistent across the region and extended into the Ridge and Valley province; 2) historic droughts (e.g., Lost Colony and Jamestown) were not only regional in occurrence but also began earlier in the growing season; and 3) multi-proxy records in the MAR have adequate correlation to warrant the collection of additional multi-century to millennial-length eastern redcedar treering chronologies for future modeling efforts.

\section{Mid-Atlantic Region Climate Patterns}

To better understand the potential influence of NAO on our May precipitation reconstruction and climate of the MAR, we calculated correlations between seasonalized NAO (AD 1826-2007; Jones et al. 1997) and seasonalized West Virginia Climate Region 6 precipitation and temperature, PC1, reconstructed May precipitation, Stahle et al.'s (1998) July PHDI reconstruction, and Cronin et al.'s salinity reconstruction (2000). Correlations were calculated for the greatest period of overlap between variables (range 112-173 years) and only significant correlations will be discussed. Confirming the results of previous research (Hartley and Keables 1998; Hartley 1999; Hurrell et al. 2003), winter NAO (December-February) is positively correlated with winter temperature $(r=0.35, \mathrm{p}<0.01)$. Additional significant 
correlations were found between summer NAO and summer temperature $(r=-0.17, \mathrm{p}<0.10)$ and fall NAO and winter temperature $(r=-0.23, \mathrm{p}<0.05)$. Salinity and July PHDI were not significantly correlated with any season of NAO.

The positive correlations between winter NAO (December-March) and PC1 $(r=0.20, \mathrm{p}<$ $0.01)$ and winter NAO and reconstructed May precipitation $(r=0.17, \mathrm{p}<0.05)$ are most pertinent to our reconstruction of May precipitation. The teleconnection between winter NAO and annual ring-width of eastern redcedar has been established previously (Cook et al. 2002). The positive correlation between winter NAO and reconstructed May precipitation is likely an effect of winter NAO on eastern redcedar tree growth rather than a true association. This interpretation is confirmed by the lack of correlation between instrumental spring precipitation and winter NAO. The correlation does suggest that winter NAO can mediate the growth response to instrumental May precipitation via the species sensitivity to winter and early spring temperature. We further investigated the influence of winter NAO on eastern redcedar's growth response to instrumental May precipitation by plotting 10-year smoothed winter NAO and the correlation coefficient between PC1 and instrumental May precipitation through time (Fig. 3b). The decrease in the correlation between PC1 and May precipitation coincides with a period of strong negative winter NAO (AD 1950s - 1970s). A strong negative winter NAO may precondition eastern redcedar to respond weakly to May precipitation, while a strong positive winter NAO may precondition a stronger growth response. The mediating effect of winter NAO on the growth response to precipitation may account for the general stability of the May precipitation reconstruction and lack of variability in the reconstruction compared to the instrumental period. Further investigation into the teleconnection between NAO and tree growth, and NAO and regional precipitation may improve our understanding of past climate in 
the MAR. Unfortunately, identifying and characterizing long-term teleconnections with Cook et al.'s (2002) multi-proxy reconstruction of the winter NAO would be inappropriate because the model utilized the Cedar Knob and bald cypress chronologies as well as many of the multicentury tree-ring records in eastern United States.

\section{Summary and conclusions}

Over the past century, the MAR has received an increasing amount of precipitation $(\sim 0.23 \mathrm{~mm} / \mathrm{yr})$. Climate models project that this trend likely will continue coincident with increasing regional temperatures (Polsky et al. 2000). Expected regional changes in climate will affect water quantity and quality and impact urban populations and ecosystem services. The dearth of multi-century to millennial-length proxy records of climate in the eastern United States has made the evaluation of current and future changes in the MAR climate difficult. In our study, two millennial-length eastern redcedar chronologies have been used to reconstruct May precipitation for the MAR of the United States. The calibration model explained $32 \%$ of the variance in the instrumental record from AD 1895-1945. The model was well verified (AD 1946-1998) by the reduction of error $(\mathrm{RE}=0.33)$ and coefficient of efficiency $(\mathrm{CE}=0.30)$ statistics. Similar to most tree-ring reconstructions, the proxy record did not capture the full range of variability in the instrumental record. Calibration and verification statistics for our reconstruction model were comparable to other single-species reconstructions (Stahle et al. 1988, 1998; Buckley et al. 2004) for the eastern United States.

The full 1248-year May precipitation reconstruction (AD 750 to 1998) was truncated at an average $85 \%$ EPS for evaluation. Substantial inter-annual and decadal variability was present throughout the entire reconstruction. The $19^{\text {th }}$ and $20^{\text {th }}$ centuries were the most variable and contained the greatest number of single-year and decadal wet and dry events since AD 1000. 
Centennial-length changes in precipitation were rare but wetter than median conditions and drier than median conditions occurred during the MWE (AD 1000-1300) and the LIA (AD 14501850), respectively. Comparisons to other regional paleo records of moisture for the MAR showed weak but significant correlations with May precipitation. While correlations were low, extreme wet and dry decadal events in May precipitation were recorded in Stahle et al.'s (1998) July PHDI reconstruction and Cronin et al.'s (2000) salinity record, suggesting that drought and pluvial events were region-wide in occurrence and began earlier in the growing season. The correlation between the first principal component of the chronologies and instrumental May precipitation weakened during the 1950s and 1960s, coincident with a period of strong negative winter NAO. Our results suggest that the dendroclimatic response of eastern redcedar to May precipitation is mediated by winter NAO via its influence on winter temperature, and this weakening may have occurred in the past when NAO was strongly negative.

Water resources in the MAR are generally abundant but managers are still challenged to provide adequate and clean water during drought and pluvial events. General circulation models predict that the MAR will experience increased temperature and precipitation in the coming decades (Polsky et al. 2000). Expected climate changes may impact the water managers' ability to provide the water quantity and quality required to sustain the increasing population of the MAR. Climate changes are expected to impact forest and wetland ecosystems putting additional stress on these habitats and their water holding and purification services on which we rely (McKenney-Easterling et al. 2000; Najjar et al. 2000; Rogers and McCarty 2000). Our May precipitation reconstruction is a conservative estimate of past climate that managers may use to assess the intensity and duration of future drought and pluvial events, and maintain a quality water supply for the MAR. Moisture-sensitive, millennial-length eastern redcedar chronologies 
help to fill the gap in the climate record of the MAR. Eastern redcedar is widespread in the

MAR and the development of an eastern redcedar network across the region could improve estimates of past precipitation. However, future work should investigate the influence of NAO on tree-ring growth response to strengthen reconstructions and better understand how NAO affects the region.

Acknowledgements. This research was funded in part by the NASA WV Space Grant Consortium, West Virginia University Eberly College of Arts and Sciences, The Explorers Club Washington D.C. Group, and National Science Foundation Doctoral Dissertation Research Grant \#0925114. The United States Forest Service, the Nature Conservancy, and Tom and Eve Firor kindly provided access to sampling locations. Thank you to David Stahle, Thomas Cronin, and their colleagues for contributing their data to the NOAA Paleoclimatology Program.

\section{References}

Barry, R., and R. Chorley, 2003: Atmosphere, Weather, and Climate. 8th ed. Routledge, New York, 421. Bartgis, R., 1993: The limestone glades and barrens of West Virginia. Castanea, 58, 69-89.

Biondi, F., 1997: Evolutionary and moving response functions in dendroclimatology. Dendrochronologia, 15, 139-150.

Biondi, F., and K. Waikul, 2004: DENDROCLIM 2002: A C++ program for statistical calibration of climate signals in tree-ring chronologies. Computers and Geosciences, 30, 303-311.

Briffa, K., 1984: Tree-climate relationships and dendrochronological reconstruction in the British Isles. Ph.D. Dissertation, University of East Anglia, 525 p.

Briffa, K., 1995: Interpreting high-resolution proxy climate data: the example of dendroclimatology. Analysis of cliamte variability: applications of statistical techniques, Eds. H. von Storch and A. Navarra, pp. 77-94, Springer-Verlag, Berlin.

Buckley, B., R. Wilson, P. Kelly, D. Larson, and E. R. Cook, 2004: Inferred summer precipitation for southern Ontario back to AD 610 as reconstructed from ring widths of Thuja occidentalis. Canadian Journal of Forest Research, 34, 2541-2553.

Cook, E. R., 1985: A time series analysis approach to tree-ring standardization. Ph.D. Dissertation, University of Arizona, Tuscon. 171 p.

Cook, E., K. Briffa, D. Meko, D. Graybill, and G. Funkhouser, 1995: The 'segment length curse' in long tree-ring chronology development for paleoclimatic studies. The Holocene, 5, 229-237.

Cook, E., R. D'Arrigo, and M. Mann, 2002: A well-verified, multiproxy reconstruction of the winter North Atlantic Oscillation index since A.D. 1400. Journal of Climate, 15, 1754-1764. 
Cook, E., and L. Kairiukstis, 1990: Methods of Dendrochronology: Applications in the Environmental Science. Kluwer Academic Publishers,

Cook, E., D. Meko, D. Stahle, and M. Cleaveland, 1999: Drought reconstructions for the continental United States. Journal of Climate, 12, 1145-1162.

Cronin, T., D. Willard, A. Karlsen, S. Ishman, S. Verardo, J. McGeehin, R. Kerhin, C. Holmes, S. Colman, and A. Zimmerman, 2000: Climatic variability in the eastern United States over the past millennium from Chesapeake Bay sediments. Geology, 28, 3-6.

Fritts, H., 1976: Tree Rings and Climate. Academic Press, New York, NY, 567.

Graumlich, L., 1987: Precipitation variation in the Pacific Northwest (1675-1975) as reconstructed from tree rings. Annals of the Association of American Geographers, 77, 19-29.

Grissino-Mayer, H., 2001: Evaluating crossdating accuracy: a manual and tutorial for the computer program COFECHA. Tree-Ring Research, 57, 205-221.

Guttman, L., 1954: Sensitivity of the Palmer hydrologic drought index to temperature and precipitation departures from average conditions. Psychometrika, 19, 149-161.

Guyette, R., E. McGinnes, G. Probasco, and K. Evans, 1980: A climate history of Boone County, Missouri from tree-ring analysis of eastern redcedar. Wood and Fiber, 12, 17-28.

Hartley, S., 1999: Winter Atlantic climate and snowfall in the south and central Appalachians. Physical Geography, 20, 1-13.

Hartley, S., and M. Keables, 1998: Synoptic associations of winter climate and snowfall variability in New England, USA, 1950-1992. International Journal of Climatology, 18, 281-298.

Hawley, F., 1937: Relationship of southern cedar growth to precipitation and run off. Ecology, 18, 398405.

Hurrell, J., Y. Kushnir, G. Otterson, and M. Visbeck, 2003: An overview of the North Atlantic Oscillation. The North Atlantic Oscillation: climatic significance and environmental impact, Eds. J. Hurrell, Y. Kushnir, G. Otterson, and M. Visbeck, Geophysical Monograph Series, American Geophysical Union, Washington, D.C.

Jones, P., T. Jonsson, and D. Wheeler, 1997: Extension to the North Atlantic Oscillation using early instrumental pressure observations from Gibraltar and South-West Iceland. International Journal of Climatology, 17, 1433-1450.

Kaiser, H., 1960: The application of electronic computers to factor analysis. Educ. Psychol. Meas., 20, 141-151.

Larson, D., 1997: Dendroecological potential of Juniperus virginiana L. growing on cliffs in western Virginia. Banisteria, 10, 13-18.

Lawson, E., 1990: Eastern Redcedar. Silvics of North America: 1. Conifers. Agriculture Handbook 654., Vol. 2 of, United States Department of Agriculture Forest Service, Washington, D.C.

Maxwell, R. S., J. A. Wixom, and A. E. Hessl, A comparison of two techniques for measuring and crossdating tree rings. Dendrochronologia,

McKenney-Easterling, M., D. DeWalle, L. Iverson, A. Prasad, and A. Buda, 2000: The potential impacts of climage change and variability on forests and forestry in the Mid-Atlantic Region. Climate Research, 14, 195-2006.

Meko, D., M. Therrell, C. Baisan, and M. Hughes, 2001: Sacremento River flow reconstructed to A.D. 869 from tree rings. Journal of the American Water Resources Association, 37, 1029-1039.

Najjar, R., H. Walker, P. Anderson, E. Barron, R. Bord, J. Gibson, V. Kennedy, C. Knight, J. Megonigal, R. O'Connor, C. Polsky, N. Psuty, B. Richards, L. Sorenson, E. Steele, and R. Swanson, 2000: The potential impacts of climate change on the mid-Atlantic coastal region. Climate Research, 14, 219-233.

National Oceanic and Atmospheric Administration, 2009: West Virginia Climate Region Six. National Climatic Data Center. Asheville, NC.

Neff, R., H. Chang, G. Knight, R. Najjar, B. Yarnal, and H. Walker, 2000: Impact of climate variation and change on mid-atlantic region hydrology and water resources. Climate Research, 14, $207-$ 218. 
Ormsbee, P., F. Bazzaz, and W. Boggess, 1976: Physiological ecology of Juniperus virginiana in oldfields. Oecologia, 23, 75-82.

Osborn, T. J., K. Briffa, and P. Jones, 1997: Adjusting variance for sample-size in tree-ring chronologies and other regional mean time series. Dendrochronologia, 15, 89-99.

Pederson, N., G. Jacoby, R. D'Arrigo, E. Cook, and B. Buckley, 2001: Hydrometeorological reconstructions from northeastern Mongolia derived from tree rings: 1651-1995. Journal of Climate, 14.

Perreault, T., M. Hache, M. Slivitzky, and B. Bobee, 1999: Detection of changes in precipitation and runoff over eastern Canada and US using a Bayesian approach. Stochastic Environmental Research and Risk Assessment, 13, 201-216.

Polsky, C., J. Allard, N. Currit, R. Crane, and B. Yarnal, 2000: The Mid-Atlantic region and its climate: past, present, and future. Climate Research, 14, 161-173.

Rogers, C., and J. McCarty, 2000: Climate change and ecosystems of the Mid-Atlantic region. Climate Research, 14, 235-244.

Stahle, D., and M. Cleaveland, 1992: Reconstruction and analysis of spring rainfall over the southeastern U.S. for the past 1000 years. Bulletin of the American Meteorological Society, 73, 1947-1961.

Stahle, D., M. Cleaveland, D. Blanton, M. Therrell, and D. Gay, 1998: The lost colony and Jamestown droughts. Science, 280, 564-567.

Stahle, D., M. Cleaveland, and J. Hehr, 1988: North Carolina climate changes reconstructed from tree rings: A.D. 372 to 1985. Science, 240, 1517-1519.

Stahle, D., E. Cook, M. Cleaveland, M. Therrell, D. Meko, H. Grissino-Mayer, E. Watson, and B. Luckman, 2000: Tree-ring data document 16th century megadrought over North America. Eos Transactions AGU, 81, 121.

Stahle, D., F. Fye, E. Cook, and R. Griffin, 2007: Tree-ring reconstructed megadroughts over North America since A.D. 1300. Climatic Change, 83, 133-149.

Stockton, C., and G. Jacoby, 1976: Long-Term Surface-Water Supply and Streamflow Levels in the Upper Colorado River Basin. Lake Powell Research Project Bulletin No. 18, Inst. of Geophysics and Planetary Physics, University of California, Los Angeles, 70.

Wigley, T., K. Briffa, and P. Jones, 1984: On the average value of correlated time series, with applications in dendroclimatology and hydrometeorology. Journal of Applied Meteorology, 23 201-213.

Woodhouse, C., 2003: A 431-year reconstruction of western Colorado snowpack from tree rings. Journal of Climate, 16, 1551-1561.

Woodhouse, C., and J. Overpeck, 1998: 2000 years of drought variability in the central United States. Bulletin of the American Meteorological Society, 79, 2693-2714. 


\section{Tables with Captions}

TABLE 1. Calibration and verification statistics for the May precipitation model.

\begin{tabular}{lllll|llll}
\hline Calibration & & & & & Verification & & & \\
\hline Period & $\mathbf{B}_{\mathbf{0}}$ & $\mathbf{B}_{\mathbf{1}}$ & $\boldsymbol{r}^{\mathbf{2}}$ & SE & Period & RE & CE & RMSE \\
$\mathbf{1 8 9 5 - 1 9 4 5}$ & 4.34 & 0.18 & 0.32 & 0.04 & $\mathbf{1 9 4 6 - 1 9 9 8}$ & 0.33 & 0.30 & 0.41 \\
$\mathbf{1 9 4 6 - 1 9 9 8}$ & 4.38 & 0.20 & 0.31 & 0.04 & $\mathbf{1 8 9 5 - 1 9 4 5}$ & 0.35 & 0.31 & 0.38 \\
$\mathbf{1 8 9 5 - 1 9 9 8}$ & 4.37 & 0.19 & 0.32 & 0.03 & & & & \\
\hline
\end{tabular}

*Significant at $\mathrm{p}<0.05 ; r=$ Pearson correlation coefficient; $\mathrm{SE}=$ Standard Error; RE $=$ reduction of error statistic; $\mathrm{CE}=$ coefficient of efficiency; RMSE = root mean square error All statistics calculated on log-transformed data.

TABLE 2. Top 10 driest and wettest years and non-overlapping 10-year events for the May precipitation reconstruction (AD 750-1998). Decadal events were calculated with a 10-year moving average ( $\mathrm{mm}$ in parentheses). Average May precipitation for the entire reconstruction is $79.3 \mathrm{~mm}$.

\begin{tabular}{crlrlrlrr}
\hline Rank & \multicolumn{2}{c}{ Dry Year } & \multicolumn{2}{c}{ Wet Year } & \multicolumn{2}{c}{ Dry Decade } & \multicolumn{2}{c}{ Wet Decade } \\
\hline 1 & 1439 & $(38.7)$ & 1865 & $(157.8)$ & $868-877$ & $(60.9)$ & $838-849$ & $(97.9)$ \\
2 & 1335 & $(39.2)$ & 922 & $(148.3)$ & $1158-1167$ & $(67.2)$ & $1049-1058$ & $(97.6)$ \\
3 & 1236 & $(40.7)$ & 1857 & $(148.3)$ & $1957-1966$ & $(67.4)$ & $1429-1438$ & $(94.2)$ \\
4 & 1930 & $(40.7)$ & 781 & $(145.7)$ & $901-910$ & $(68.4)$ & $781-790$ & $(91.6)$ \\
5 & 1879 & $(41.3)$ & 1897 & $(142.7)$ & $1764-1773$ & $(68.5)$ & $1857-1866$ & $(90.5)$ \\
6 & 1896 & $(41.9)$ & 1842 & $(142.5)$ & $1872-1891$ & $(68.7)$ & $1989-1998$ & $(91.0)$ \\
7 & 1401 & $(42.1)$ & 1808 & $(142.4)$ & $1465-1474$ & $(69.0)$ & $1671-1680$ & $(90.8)$ \\
8 & 1708 & $(42.6)$ & 846 & $(139.7)$ & $1252-1261$ & $(69.1)$ & $1931-1940$ & $(90.6)$ \\
9 & 1010 & $(42.7)$ & 997 & $(137.9)$ & $1911-1920$ & $(69.5)$ & $1237-1246$ & $(89.9)$ \\
10 & 1755 & $(43.5)$ & 1189 & $(136.0)$ & $1590-1599$ & $(69.5)$ & $920-929$ & $(89.5)$ \\
\hline
\end{tabular}




\section{List of Figures}

FIG. 1. Map of the Mid-Atlantic Region including the Smoke Hole and Cedar Knob eastern redcedar tree-ring sampling locations, West Virginia Climate Region 6, Stahle et al.'s (1998) bald cypress tree-ring sampling locations, the Virginia/North Carolina PHDI Climate Region reconstructed by Stahle et al., and the location of Cronin et al.'s (2000) Chesapeake Bay salinity record.

FIG. 2. Residual chronologies for the Smoke Hole $(a)$ and Cedar Knob (b) locations with sample size and expressed population signal (EPS). The horizontal line at $85 \%$ EPS represents a suggested chronology cut-off point (Wigley et al. 1984). We chose to truncated our chronologies at $\mathrm{AD} 750$ when the average EPS between sites fell below the cut-off point.

FIG. 3. (a) Correlation analysis results of PC1 and West Virginia Climate Region 6 temperature and precipitation. The capitalized months are from the previous year. (b) Correlation analysis between PC1 and May precipitation using a 35-year moving window (black line) to assess time stability of the relationship and instrumental winter North Atlantic Oscillation (NAO; Jones et al. 1997 ) index smoothed with a 10 -year $4^{\text {th }}$ order spline (gray line). The dashed line is the mean winter NAO for December-February. *Significant at $p<0.05$ for the instrumental period 18961998.

FIG. 4. Calibration and verification of modeled May precipitation (gray line) compared to instrumental record (black line). The trend line shows the $0.23 \mathrm{~mm} /$ year increase in recorded May precipitation from 1895-1998. *Significant at $\mathrm{p}<0.05$.

FIG. 5. Full May precipitation reconstruction from AD 750-1998. The gray line represents the annual predicted values. A 10 -year $4^{\text {th }}$ order smoothing spline is used to highlight decadal trends (thick black line).

FIG. 6. Box-and-whisker plots $\left(10^{\text {th }}, 25^{\text {th }}, 50^{\text {th }}, 75^{\text {th }}\right.$, and $90^{\text {th }}$ percentiles $)$ were calculated for each century of the May precipitation reconstruction and the $20^{\text {th }}$ century instrumental period. Dashed gray lines represent the $10^{\text {th }}, 50^{\text {th }}$, and $90^{\text {th }}$ percentiles calculated using the entire reconstruction for comparison.

FIG. 7. Regional comparison of the May precipitation reconstruction (a) to Stahle et al.'s (1998) July PHDI reconstruction (b) and Cronin et al.'s (2000) salinity reconstruction $(c)$. The thick black line in the top two reconstructions represents a 10 -year $4^{\text {th }}$ order smoothing spline to enhance decadal trends. Raw data (rather than a spline) from the salinity record are presented because the record does not have annual resolution. Red and blue bars represent extreme decadal droughts and pluvials (Table 2), respectively, recorded in the May precipitation reconstruction. The vertical dashed lines represent the Lost Colony (1587-1689) and Jamestown (1606-1612) droughts from Stahle et al., respectively. 
Figures with Captions

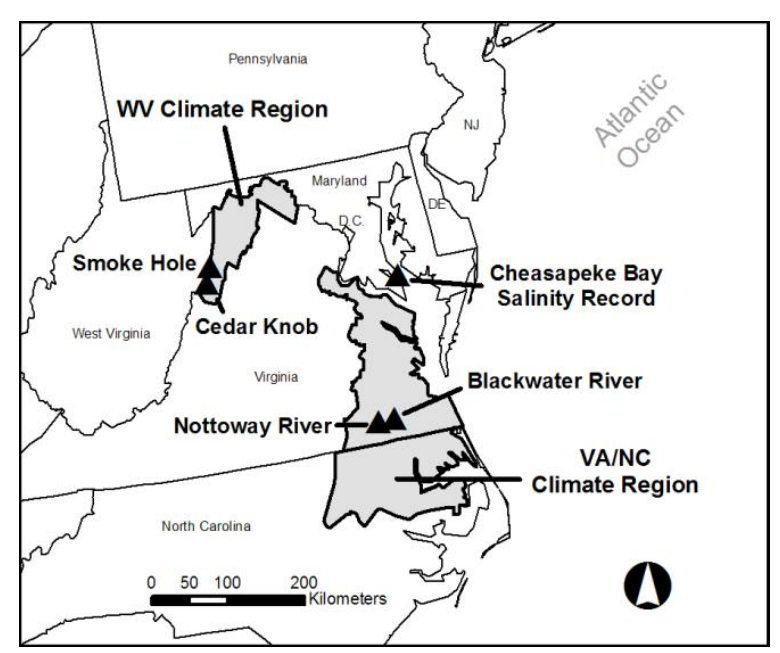

FIG. 1. Map of the Mid-Atlantic Region including the Smoke Hole and Cedar Knob eastern redcedar tree-ring sampling locations, West Virginia Climate Region 6, Stahle et al.'s (1998) bald cypress tree-ring sampling locations, the Virginia/North Carolina PHDI Climate Region reconstructed by Stahle et al., and the location of Cronin et al.'s (2000) Chesapeake Bay salinity record. 


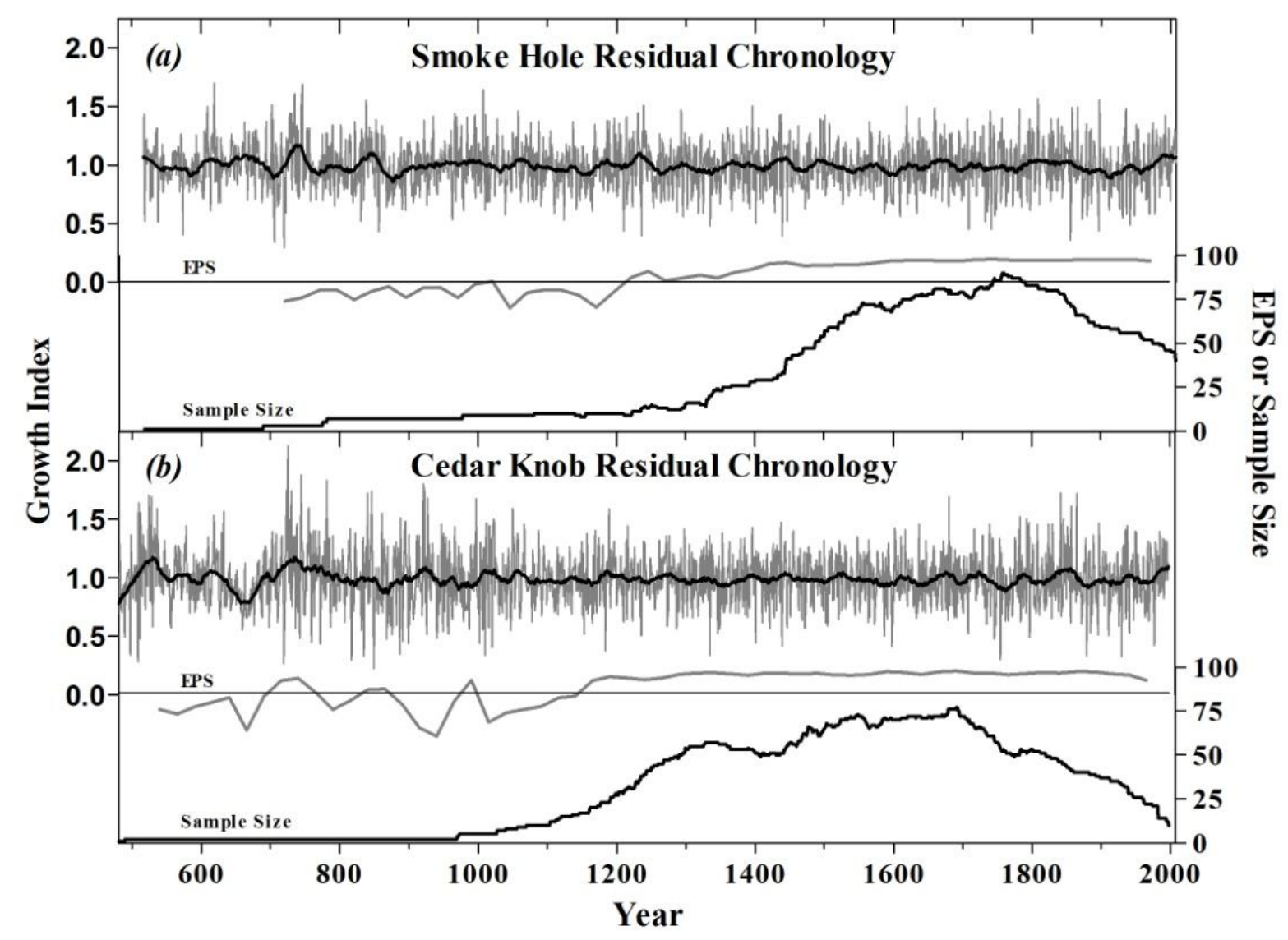

FIG. 2. Residual chronologies for the Smoke Hole $(a)$ and Cedar Knob $(b)$ locations with sample size and expressed population signal (EPS). The horizontal line at $85 \%$ EPS represents a suggested chronology cut-off point (Wigley et al. 1984). We chose to truncate our chronologies at $\mathrm{AD} 750$ when the average EPS between sites fell below the cut-off point. 

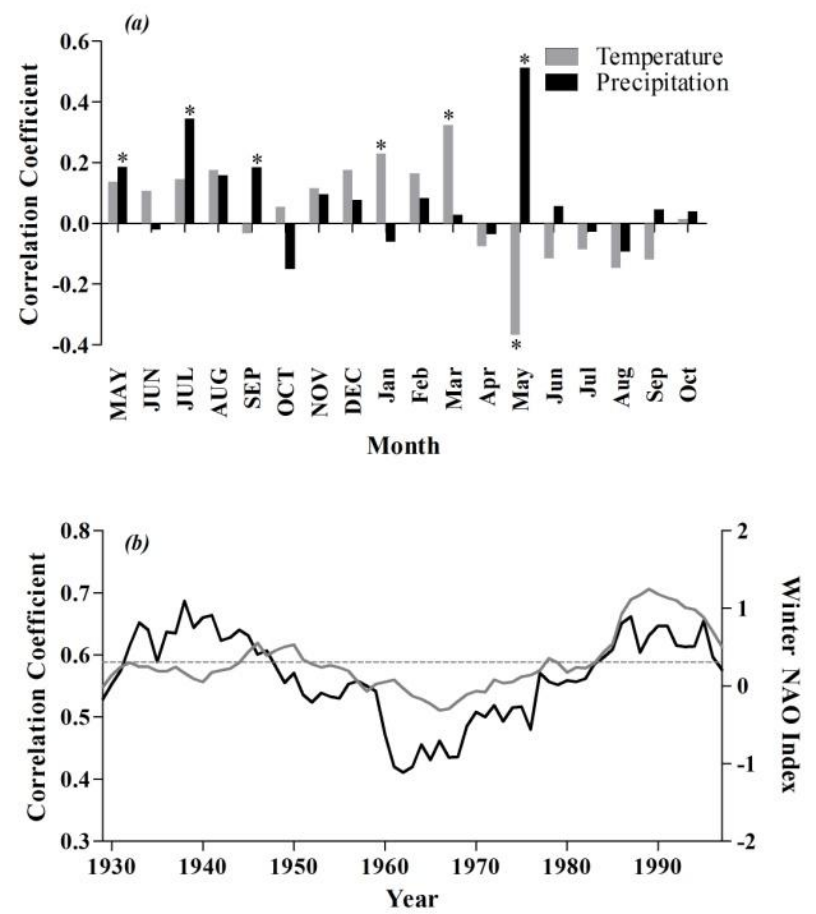

FIG. 3. (a) Correlation analysis results of PC1 and West Virginia Climate Region 6 temperature and precipitation. The capitalized months are from the previous year. (b) Correlation analysis between PC1 and May precipitation using a 35-year moving window (black line) to assess time stability of the relationship and instrumental winter North Atlantic Oscillation (NAO; Jones et al. 1997 ) index smoothed with a 10 -year $4^{\text {th }}$ order spline (gray line). The dashed line is the mean winter NAO for December-February. *Significant at $\mathrm{p}<0.05$ for the instrumental period 18961998. 


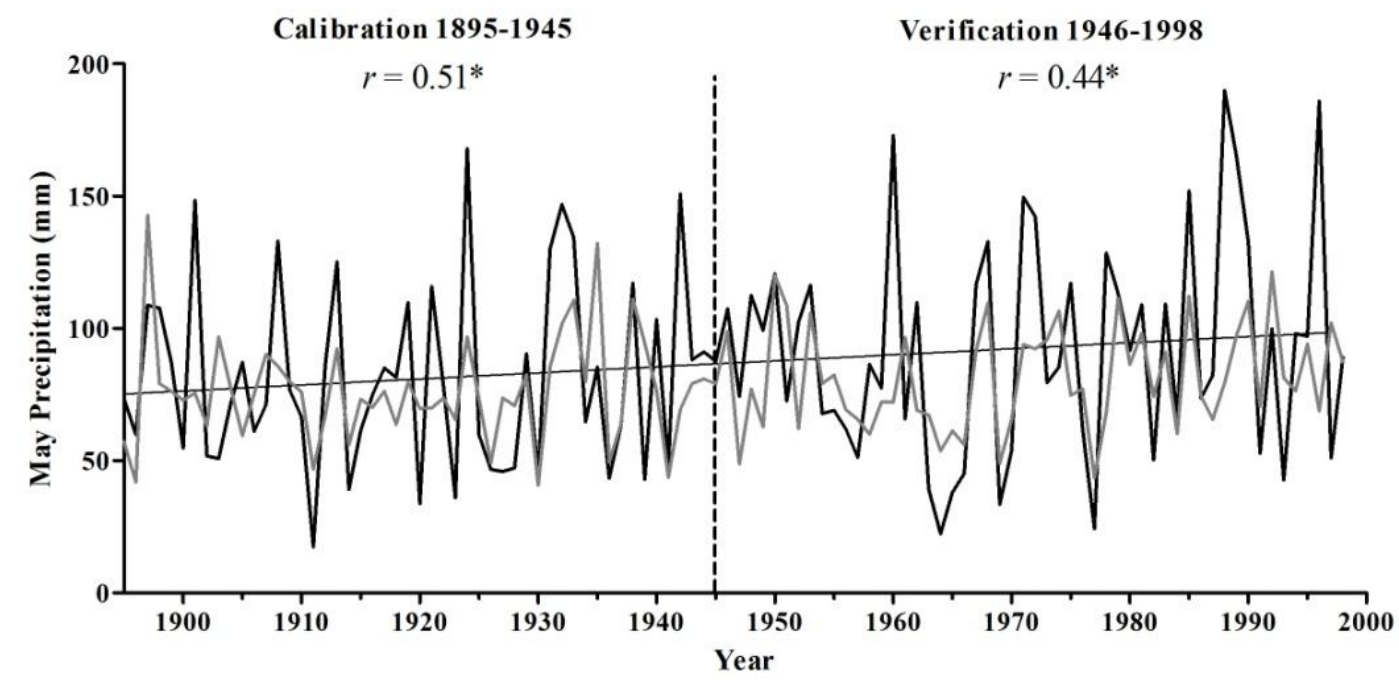

FIG. 4. Calibration and verification of modeled May precipitation (gray line) compared to instrumental record (black line). The trend line shows the $0.23 \mathrm{~mm} /$ year increase in instrumental May precipitation from 1895-1998. *Significant at $\mathrm{p}<0.001$.

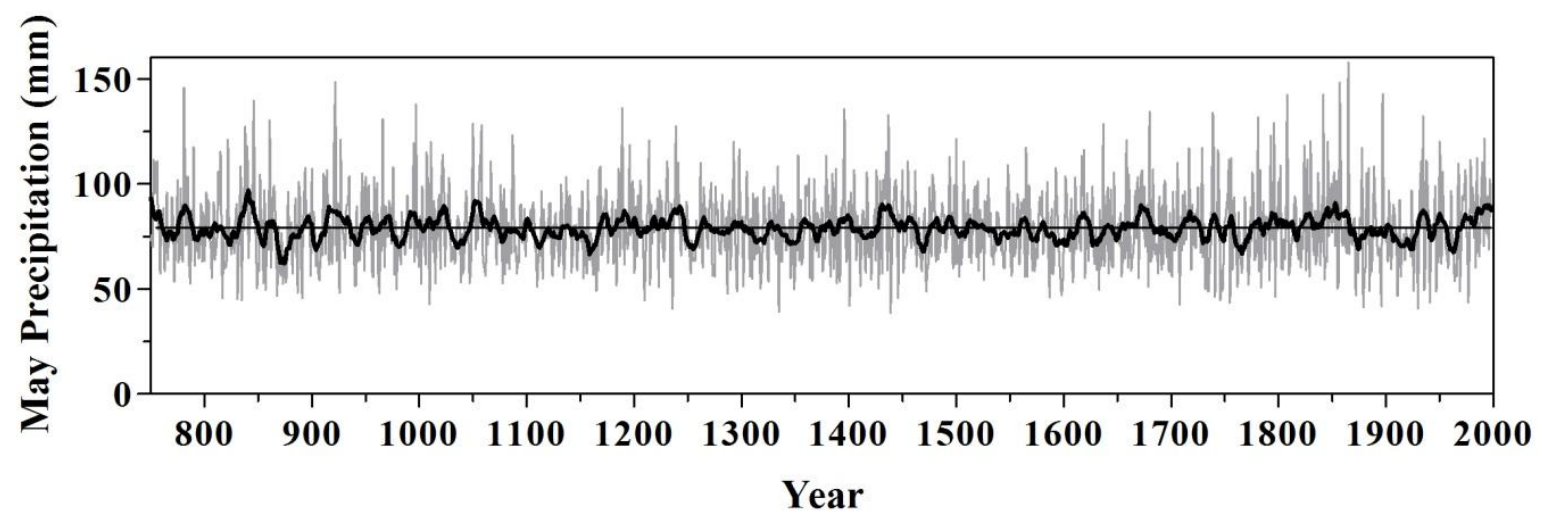

FIG. 5. Full May precipitation reconstruction from AD 750-1998. The gray line represents the annual predicted values. A 10 -year $4^{\text {th }}$ order smoothing spline is used to highlight decadal trends (thick black line). 


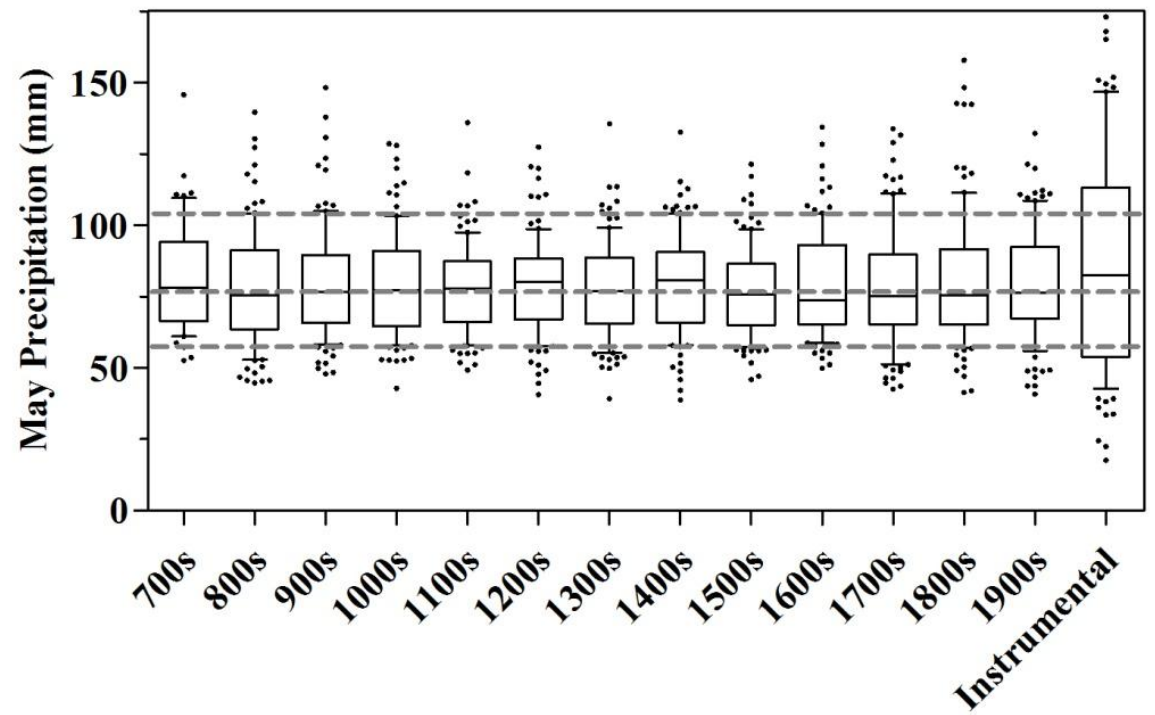

\section{Century}

FIG. 6. Box-and-whisker plots $\left(10^{\text {th }}, 25^{\text {th }}, 50^{\text {th }}, 75^{\text {th }}\right.$, and $90^{\text {th }}$ percentiles $)$ were calculated for each century of the May precipitation reconstruction and the $20^{\text {th }}$ century instrumental period. Dashed gray lines represent the $10^{\text {th }}, 50^{\text {th }}$, and $90^{\text {th }}$ percentiles calculated using the entire reconstruction for comparison. 


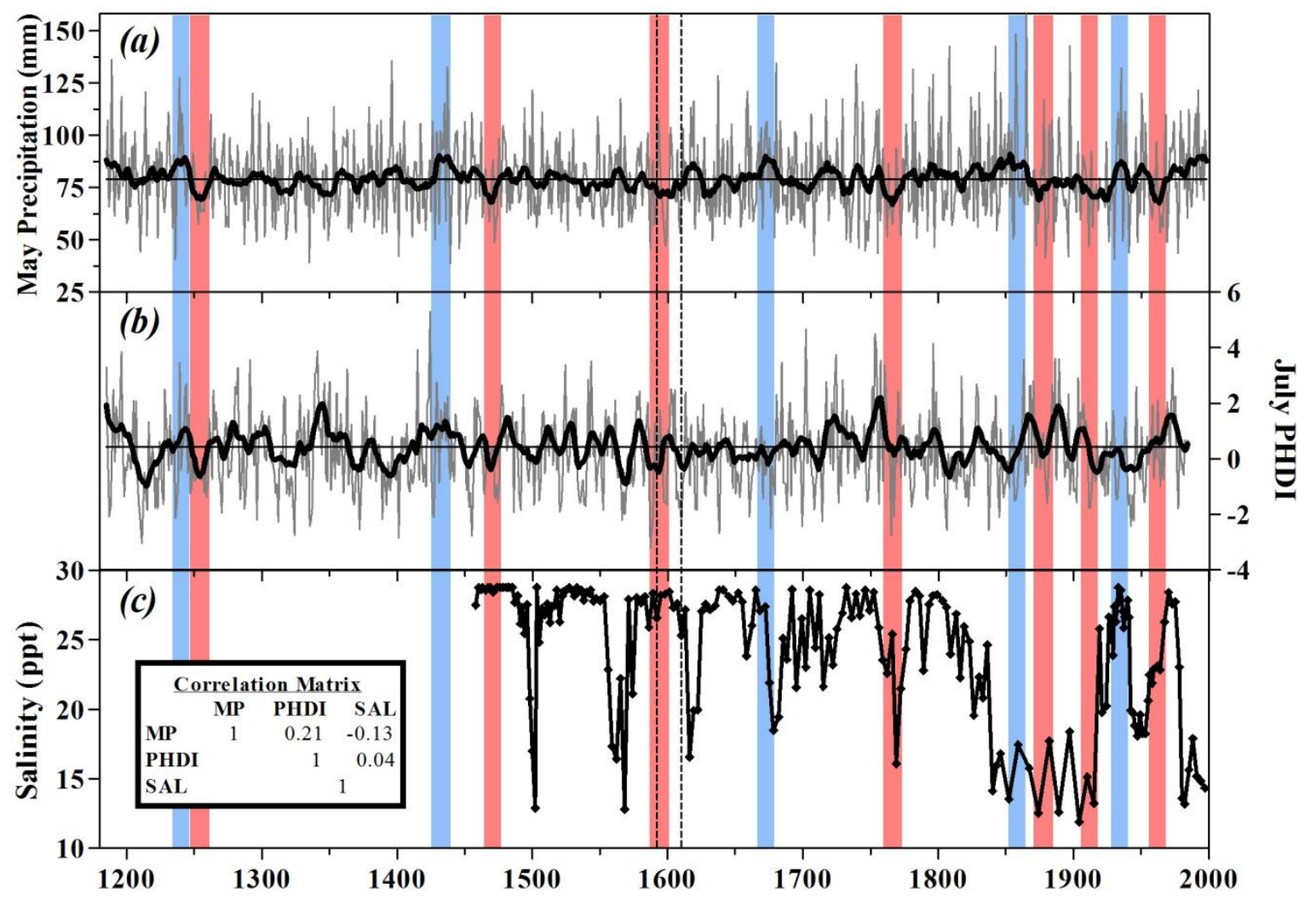

FIG. 7. Regional comparison of the May precipitation reconstruction (a) to Stahle et al.'s (1998) July PHDI reconstruction (b) and Cronin et al.'s (2000) salinity reconstruction (c). The thick black line in the top two reconstructions represents a 10 -year $4^{\text {th }}$ order smoothing spline to enhance decadal trends. Raw data (rather than a spline) from the salinity record are presented because the record does not have annual resolution. Red and blue bars represent extreme decadal droughts and pluvials (Table 2), respectively, recorded in the May precipitation reconstruction. The vertical dashed lines represent the Lost Colony (1587-1689) and Jamestown (1606-1612) droughts from Stahle et al., respectively. 


\section{Chapter 3: A Multi-Species Tree-Ring Reconstruction of Potomac River Streamflow (950-2001)}

R. Stockton Maxwell ${ }^{1}$, Edward R. Cook $^{2}$, Neil Pederson ${ }^{2}$, and Amy E. Hessl ${ }^{1}$

${ }^{I}$ West Virginia University, Department of Geology and Geography, Morgantown, WV

${ }^{2}$ Lamont-Doherty Earth Observatory, Tree-Ring Laboratory, Palisades, $N Y$

To be submitted to Water Resources Research (AGU) or the Journal of the American Water Resources Association

Corresponding Author Address:

R. Stockton Maxwell, West Virginia University, Department of Geology and Geography, P.O. Box 6300, Morgantown, WV 26506-6300

Email: stockton.maxwell@gmail.com 


\begin{abstract}
Mean May-September Potomac River streamflow was reconstructed from 950-2001 using a network of tree-ring chronologies $(n=27)$ representing multiple species. We chose a nested principal components reconstruction model to maximize the use of available chronologies backward in time. Explained variance during the period of calibration ranged from $20 \%$ to $53 \%$ depending on the number and species of chronologies available in each 25 -yr time-step. The model was verified by two rigorous goodness-of-fit tests, the coefficient of efficiency (CE) and the reduction of error statistic (RE). The RE and CE never fell below zero, suggesting the model had explanatory power over the entire period of reconstruction. Beta weights indicated a loss of explained variance during the 1550-1700 period that we hypothesize was caused by the reduction in total number of predictor chronologies and loss of important predictor species. Frequency, intensity, and duration of drought and pluvial events were examined to aid water resource managers. We found that the instrumental period did not represent adequately the full range of annual to multi-decadal variability present in the reconstruction. Our reconstruction of mean May-September Potomac River streamflow was a significant improvement over the previous reconstruction because it expanded the seasonal window, lengthened the record by 780 years, and better replicated the mean and variance of the instrumental record. By capitalizing on variable phenologies and tree-growth responses to climate, multi-species reconstructions may provide significantly more information about past hydroclimate, especially in regions with low aridity and high tree species diversity.
\end{abstract}




\section{Introduction}

The Potomac River is the primary water resource for the Washington, DC Metropolitan Area (WMA) supplying $\sim 75 \%$ of the water demand for nearly 4 million residents [Kame'enui et $a l ., 2005]$. In the Potomac River Basin (PRB), a variety of human and natural factors influence water quantity and quality but the underlying climatic variability of the region is likely the most important component [Neff et al., 2000; Polsky et al., 2000]. Previous drought planning operations in the WMA have utilized the 1930 drought event to assess the ability of the water supply system to withstand future droughts. In 2002, the water supply system was tested by a drought that rivaled the 1930 event in intensity. While the 2002 drought was less severe than expected, below normal precipitation, record low groundwater levels, and record low daily streamflows in the winter and spring necessitated the augmentation of Potomac River streamflow from three reservoirs in the Potomac River Basin, reducing two reservoir storage levels to $\sim 65 \%$ of baseline [Kame'enui et al., 2005; Lorie and Hagen, 2007]. The instrumental record, which extends back to the 1890s, of Potomac River streamflow includes not only important drought events but also pluvial events that have affected the water supply system. In 1996, record high flood events occurred in January and September making it the first time during the instrumental period that two large flooding events happened in a single year. The instrumental record is useful for assessing the water supply system's ability to operate under short-term drought and pluvial events but it may not represent the full range of climatic variability over past centuries. Water resources in the region are generally abundant but periodic drought and pluvial events require careful management of the water resources and the surrounding watersheds to minimize the negative impact of changes in water quantity and quality [Neff et al., 2000; Najjar et al., 2000]. Managers face additional challenges because the Mid-Atlantic Region is predicted to 
become warmer and wetter in the coming decades [Polsky et al., 2000]. Increasing demands combined with climate variability may stretch the current water resource system in the PRB beyond levels experienced during the $20^{\text {th }}$ century.

In regions with short records of instrumental data, tree rings may be used as a proxy to extend the streamflow record having important implications for water resource management [Rice et al., 2009; Woodhouse and Lukas, 2006a]. Previous streamflow studies indicate that the instrumental gage records of the $20^{\text {th }}$ and $21^{\text {st }}$ centuries represent only a portion of the full range of streamflow variability in the past several centuries [e.g., Akkemik et al., 2008; Meko et al., 1995; Woodhouse et al., 2006]. In the PRB, Cook and Jacoby [1983] reconstructed the JulySeptember streamflow period for the Potomac River (Point of Rocks, Maryland) from 1730-1977 using five tree-ring chronologies from multiple species. In Cook and Jacoby's reconstruction, the 1930 drought was surpassed several times but the prolonged regional drought of the $1960 \mathrm{~s}$ was the most severe since 1730. The results of Cook and Jacoby suggest that water supply models calibrated on low-flow periods during the 1930s may not adequately forecast the ability of the water supply system to withstand more extreme drought events recorded in the reconstructed streamflow record. Additionally, several long periods ( $\sim 50$ years) generally above and below the long-term median were noted. Cook and Jacoby's results clearly indicate that the instrumental record of streamflow is not sufficiently long to determine the frequency, intensity, and duration of long-term drought and pluvial events; however, their record represents less than 300 years of streamflow variability.

The use of multiple species in the reconstruction of climate and streamflow is common in locations across the globe [e.g., Frank and Esper, 2005; Meko et al., 2001; Pederson et al., 2001], but multi-species methods rarely have been used in the eastern United States [i.e., Cook 
and Jacoby, 1977, 1983]. In the eastern deciduous forest, tens of tree species grow together across a variety of sites, each with a different response to climate resulting from differing locations (elevation, soils, topography) as well as species and population level phenological variation. While site history and stand dynamics can affect tree-growth, the careful standardization of individual series can produce chronologies with a common climatic signal. In this paper, we use a set of existing chronologies including nine different species growing in or near the PRB to reconstruct mean May-September Potomac River streamflow from 950-2001. Nested principal components regression models were calculated at 25-year time-steps to maximize the use of available predictor chronologies as the model moved backward in time. Such time-varying reconstruction models are useful because the longevity of species ranges from 300 to 900 years in our study. Further, we discuss the use and effect of multiple species on the calibration and verification of the streamflow reconstruction model. To facilitate the use of the reconstruction for water resource management, we analyze the frequency, intensity, and duration of drought and pluvial events in the reconstruction and compare the reconstruction to the instrumental record. Finally, we compare our mean May-September Potomac River streamflow reconstruction to Cook and Jacoby's [1983] original June-August reconstruction of the same gage.

\section{Methods}

\subsection{Streamflow Data}

The PRB extends across $>37,000 \mathrm{~km}^{2}$ including parts of Virginia, Maryland, West Virginia, Pennsylvania, and the District of Columbia (Fig. 1). The headwaters of the Potomac River begin in the mountains of West Virginia (North Branch) and Virginia (South Branch), 
where it flows $616 \mathrm{~km}$ to the Chesapeake Bay making it the $4^{\text {th }}$ longest river on the Atlantic Coast. Instrumental Potomac River streamflow data (1895-2007) were collected for the Point of Rocks, Maryland gage from the United States Geological Survey (Fig. 2; 39¹6’24.9” N, 77³2’35” W). The Point of Rocks record is the longest available dataset of Potomac River streamflow and is relied upon for water resource planning in the Washington, D.C. metropolitan area [Kame'enui et al., 2005]. The average flow of the Potomac River at Point of Rocks, Maryland for the period of record is $270 \mathrm{~m}^{3} / \mathrm{sec}$. The maximum flow $\left(13,600 \mathrm{~m}^{3} / \mathrm{sec}\right)$ occurred in March $19^{\text {th }}, 1936$ and the minimum flow $\left(15 \mathrm{~m}^{3} / \mathrm{sec}\right)$ was recorded in September $11^{\text {th }}, 1966$. The low-flow period extending from July to November is a primary concern of water resource managers in maintaining the water quantity and quality in the Potomac River Basin (Fig. 2). Two reservoirs are located upstream of the Point of Rocks gage. The Savage and JenningsRandolph reservoirs were completed in 1952 and 1982, respectively, and are used to augment Potomac River streamflow when water demand exceeds supply during the low-flow period. In addition to low-flow events, pluvial events challenge the ability of water resource managers to maintain adequate levels of water quality for human and environmental needs [Neff et al., 2000]. Additional adjusted streamflow records for the Point of Rocks gage were obtained from the Interstate Commission on the Potomac River Basin (ICPRB), a collaborative water resource management agency for the WMA. Streamflow records were adjusted for reservoir outflows, and two monthly time series with and without consumptive use were created, respectively. Preliminary correlation and response function analysis between tree-ring chronologies and the three gage records (i.e., 1 unadjusted and 2 adjusted) showed that the unadjusted USGS data had the strongest and most time-stable relationship to tree growth (data not presented). Further 
investigation is needed to determine the effect of streamflow adjustments on the correlation with tree growth. Subsequent analysis used the unadjusted USGS streamflow record.

The USGS reported two gage changes in 1902 and 1929 that may have affected the homogeneity of the streamflow record [United States Geological Survey, 2010]. Additionally, Brooks [1910] documented extensive fire and logging activity around the turn of the $20^{\text {th }}$ century in the eastern counties of West Virginia that may have affected Potomac River streamflow. The effects of land clearing activities on streamflow in the region are well documented [Lull and Sopper, 1966; Patric and Reinhart, 1971]. Cook and Jacoby [1983] previously investigated the homogeneity of the Point of Rocks gage using double mass analysis to determine if the Point of Rocks gage changes or logging events in the early 1900s created anomalous values. The double mass analysis compared the streamflow record to regional precipitation records and showed no effect of the gage changes. However, the period of intense logging activity created a departure from the expected flow prior to 1907. We truncated the instrumental streamflow record (19072007) to avoid possible spurious results associated with land clearing and disturbance. Next, monthly streamflow data were examined for normality using normal quantile plots and the Shapiro-Wilk $W$ goodness-of-fit test of the normal distribution. All months were not adequately modeled by the normal distribution $(W=0.54$ to $0.92 ; \mathrm{p}<0.0001)$ and were log-transformed. Streamflow data were later back-transformed into the original units $\left(\mathrm{m}^{3} / \mathrm{sec}\right) . \log$ transformations of data are necessary to meet the assumptions of multiple linear regression but the back-transformation process causes a reduction in the mean and variance.

\subsection{Tree-Ring Network}

Tree-ring data for the streamflow reconstruction came from both unpublished collections and published chronologies freely available on the International Tree-Ring Data Bank [Fig. 1; 
International Tree-Ring Data Bank, 2010]. Chronologies were selected from locations in the Appalachian Mountains and east to the Atlantic Coast in Maryland, Pennsylvania, West Virginia, and Virginia. The collection sites vary from coastal lowlands to dry upland slopes and from closed to open canopy forests. At a few sites, chronologies for more than one species were developed. A total of 27 chronologies with the common period 1700-1977 were compiled from the region (Table 1). The screening process for inclusion in the streamflow reconstruction model is described in the following section. The range of species used in our study include Carya ovata Mill., Juniperus virginiana L., Liriodendron tulipifera L., Magnolia acuminata L., Picea rubens Sarg., Quercus alba L., Q. prinus L., Taxodium distichum L., and Tsuga Canadensis L. While many chronologies are located outside of the PRB, chronologies several hundred kilometers away from a climate or streamflow recording station may be significantly correlated with streamflow because of regional climate patterns [Cook et al., 1999; Woodhouse and Lukas, 2006b].

Each chronology was examined prior to standardization and individual tree-ring series were removed if they were less than 125 years in length to preserve low-frequency signals associated with climate and streamflow [Cook et al., 1995]. After short series were removed, the number of series per sampling site ranged from 13 to 152 and median series length at a site ranged from 169 to 376 years (Table 1). The computer program ARSTAN was used to standardize each tree-ring series using a smoothing spline two-thirds the length of a series to remove biological growth trends, and growth and suppression trends associated with closed canopy forests [Cook, 1985]. A two-thirds spline used on series with a 125-year segment length retains frequencies up to $\sim 80$ years and produces chronologies suitable for analysis of multidecadal trends in reconstructed streamflow. Low-order autocorrelation (e.g., 1-3 year lag) was 
removed from each series with an autoregressive moving average model. Then, the tree-ring series for each site were averaged into residual chronologies using a robust mean [Cook, 1985] and the variance of the chronologies was stabilized with the Briffa RBAR-weighted method to account for changes in variance due to the reduction in sample size backward in time [Osborn et al., 1997].

\subsection{Reconstruction Methods}

To determine the seasonal window for reconstructing streamflow, we conducted a correlation function analysis for individual streamflow months (log-transformed) of the current growing season (May-September) with the 27 available chronologies for the common period 1700-1977. Chronologies in years $t$ and $t+1$ were included in the correlation analysis, for a total of 54 predictors, because of the known preconditioning effect of previous year water availability on current year growth in the Mid-Atlantic region [Cook et al., 1999; Maxwell et al. submitted; Stahle et al., 1998]. First, individual streamflow months were tested for autocorrelation using low-order autoregressive (AR) model [Box and Jenkins, 1970]. The minimum Akaike information criterion (AIC) was used to choose the AR model order $p$ [Akaike, 1974]. Only May and June streamflow showed significant autocorrelation with model orders AR(3) and AR(1), respectively, and these months were prewhitened prior to the correlation analysis. We found that a subset of the 54 predictors (years $t$ and $t+1$ ), ranging from 50-52 predictors, were significantly correlated $(\mathrm{r}>|0.025| ; \mathrm{p}<0.05)$ with streamflow in each month of the growing season (data not presented). Our results build on Cook and Jacoby's [1983] previous analysis of mean JulySeptember Potomac River streamflow by expanding the reconstructed season of streamflow from May-September. Therefore, we chose to include the full pool of 54 predictors in our modeling process of mean May-September Potomac River streamflow. Mean May-September streamflow 
showed no significant autocorrelation and was not prewhitened prior to calibration and verification of the reconstruction model.

We chose a nested principle components regression (PCR) model to reconstruct mean May-September Potomac River streamflow and account for the decrease in the number of predictor chronologies backward in time [Cook et al., 2002, 1999]. Such time-varying models utilize the available tree-ring chronologies in a period to gain greater predictive skill while lengthening the reconstruction. In our study, the first model was calibrated for the common period of all chronologies (1700-1976). A second model was calibrated one 25-year time-step earlier (1675-1976) using fewer chronologies available for the longer period, and so forth. An additional time-step from 1700-2001 was modeled to include more recent tree-ring collections. This resulted in a total of 51 separate regression model runs, each with its own set of calibration and verification statistics. Then, the models were spliced together to estimate streamflow backwards in time utilizing the near-maximum number of predictor chronologies available for each time-step.

The nested PCR design is described in detail by Cook et al. [1999] and Cook et al. [2002], therefore, we will give only a brief explanation of the model procedure. Predictors entered the PCR model if they were significantly correlated $(r>|0.025|$; $p<0.10)$ with mean May-September streamflow during the calibration period (1931-1976). A principal components analysis (PCA) was calculated on the remaining pool of predictors. Following the KaiserGuttman rule, the first $n$ eigenvectors with eigenvalues $>1$ were retained for the multiple regression, further reducing the dimensionality of the data. The final subset of principal components in the regression model was determined using the minimum AIC that includes a penalty term for increasing the number of predictors in the model [Akaike, 1974]. 
The period of overlap between the instrumental record of streamflow and tree-ring chronologies (1907-1976) was split into two periods for calibration (1931-1976) and verification (1907-1931) of the nested PCR models. The calibration models were verified with two rigorous tests of fit, the reduction of error statistic (RE) and the coefficient of efficiency [CE; Fritts, 1976; Cook et al., 1999]. The RE ranges from $-\infty$ to +1 . When RE exceeds zero, the calibration model shows greater skill than the mean of the instrumental data from the calibration period. The CE has the same range and calculation except the $\mathrm{CE}$ relies on the verification period mean as a baseline of predictive skill, making the CE more difficult to pass. Finally, we determined the relative influence of each predictor chronology in the common period nest (1700-1976) of the reconstruction by taking the absolute value of the standardized regression coefficients or beta weights [Cook et al., 2002, 1999]. The beta weights represent the principal component loadings of the predictor chronologies in the model and are calculated by multiplying the matrix of retained eigenvectors by the vector of beta weights in principal component space [Cook et al., 1994]. We summed the beta weights for chronologies where the $t$ and $t+1$ series were included as predictors, and then, divided by the total sum of the beta weights for all predictors in the calibration model to calculate a measure of relative variance explained $(0-100 \%)$ for each chronology. Results are mapped and discussed in terms of species and site importance.

\section{Reconstructed Potomac River Streamflow}

\subsection{Analysis of the Reconstruction}

Fifty-one nested PCR models were calculated using the 25-year time-step to reconstruct mean May-September Potomac River streamflow from 481-2001. The reconstruction calibration and verification statistics remained significant $(\mathrm{p}<0.05)$ for the entire period and the RE and CE 
statistics never became negative, suggesting that the model provided more information than the calibration or verification means. While the reconstruction demonstrates statistical strength for the entire 481-2001 period, we have truncated the reconstruction at 950 because of weakening verification statistics and a reduction in sample size. Models before 950 were calculated on only two Juniperus virginiana chronologies from West Virginia representing at most nine individual tree-ring series and five trees. The reduction in sample size resulted in a decrease in the variance explained $\left(r^{2}\right)$ and poor model performance with RE and CE near zero.

For the 950-2001 reconstruction period, the explained variance of the model during the calibration period (1931-1976) ranged from $20 \%$ to $53 \%$ (Fig. 3). The reduction in explained variance backward in time is attributed to the decrease in the number and species-type of predictors available for reconstruction. The explained variance during the verification period (1907-1930) ranged from $14 \%$ to $50 \%$. The RE and CE were nearly identical in each time-step and both remained positive. However, the verification statistics during the common period of all predictors (1700-1977) were not as strong as expected, given the number of chronologies available. Going backward in time, RE and CE increased briefly during the $17^{\text {th }}$ century and fluctuated for approximately 175 years until the number of predictor chronologies fell to five in 1525. The increase in RE and CE suggests that a more parsimonious model may be constructed by lengthening the common period and excluding shorter chronologies. While a reduction in the number of chronologies strengthened the verification statistics, the nested PCR models saw an accompanying decrease in the calibration $r^{2}$. The number of available predictor chronologies leveled off prior to 1525 with a corresponding plateau in explained variance during the verification period. 
Further inspection of the nested PCR models during the calibration and verification periods demonstrated the effect of the changing availability of predictor chronologies on the correlation with instrumental streamflow (Fig. 4). First, decadal trends present in the instrumental record were adequately modeled across nested models. Most notably, the duration and intensity of the mid-1960s drought was well replicated in most models. Second, single year drought and pluvial events, such as the 1930 drought, were replicated but models tended to underestimate extreme values. Third, a 1-year lag between the instrumental record and the proxy records occurred several times. For example, the 1949 peak in streamflow carried into 1950 for some of the nested models. Although chronologies were prewhitened prior to modeling, the carry-over is likely the preconditioning effect of the previous year's moisture on the subsequent year's radial growth and suggests that not all of the persistence in the predictor chronologies was removed. Fourth, annual to multi-year periods of disagreement between nested models occurred throughout the record (e.g., 1910,1920 , and 1940). The reduction in available chronologies backward (and forward) in time and the changing species composition in the predictor pool create discrepancies between nested models during the calibration/verification period. From our initial correlations with monthly streamflow, we know that some species are better correlated with early growing-season streamflow than late growing-season streamflow. Overall, small differences in predicted streamflow were seen in any given year but multi-year and decadal trends were preserved reasonably well. In cases of disagreement, differences in the number of predictor chronologies and type of tree species likely affected the nested models.

\subsection{Species Importance}

The beta weights for the common period 1700-1976 are shown in Figure 1 (right panel). Fifty-two predictors (27 chronologies) from years $t$ and $t+1$ were retained for modeling and 
weights were distributed across the region and species type. The mean relative variance explained for all chronologies was 3.7\%, ranging from $0.48 \%$ to $7.24 \%$. The most important species were $Q$. prinus, $T$. canadensis, and $T$. distichum in terms of abundance and relative variance explained. However, species represented only once (i.e., C. ovata, M. acuminata, $L$. tulipifera) had some of the highest beta weights (Fig.1). The single species collections were all located at the Fiddler's Green site in the Blue Ridge Mountains of Virginia, presenting a possible confound between species and site importance, but future collections of these species across the region likely would strengthen the reconstruction. The majority of predictors had greater loadings in year $t$ but $J$. virginiana, C. ovata, T. canadensis, and $P$. rubens had greater loadings in year $t+1$, demonstrating the differential species response to moisture variability through the growing season. For species with large beta weights for $t+1$ predictors, late season moisture has a preconditioning effect on the next year's growth. The resulting species differences in $t+1$ predictors might be exploited further to strengthen reconstructions of August-October streamflow. Approximately $27 \%$ of the beta loadings were negative, suggesting that the treering response to May-September moisture is not homogeneous across the region and that the distribution of moisture across sites is not even.

The loss of key predictor species and chronologies as the nested PCR model was shifted backward (and forward) in time resulted in fluctuating calibration and verification statistics (Fig. 3 and Table 1). The shift from 1700 back to 1650 lost five predictor chronologies including the L. tulipifera and M. acuminata chronologies from Fiddler's Green, VA that together explained $14 \%$ of the relative variance in the common period 1700-1976. At each 25-year time step, additional species and chronologies that explained 5-7\% each of the relative variance during the common period were not available in the predictor pool. By 1550, only eight predictor 
chronologies representing four species remained. The eight predictor chronologies collectively explained $24 \%$ of the common period relative variance. As previously mentioned, the increase in verification statistics in the 1625-1700 period may be an effect of the reduction in the number of available chronologies from the common period. We experimented with a more stringent rule for inclusion into the predictor pool in which the correlation with streamflow had to be significant at $p<0.05$ but found little difference between models through time. The reduction in sample size in individual chronologies ending from 1550-1700 is a second explanation for the fluctuation in the calibration and verification statistics. Typically, less than five individual series were used to develop the chronologies in early decades resulting in a decrease in the expressed population signal (EPS) in each chronology. The EPS is a measure of the common variance in a chronology and weakens as sample size decreases [Briffa, 1984; Wigley et al., 1984]. Future modeling efforts may be strengthened by closer examination of individual chronologies and adjustment of chronology length based on the EPS. Our reconstruction results suggest that additional sampling should take place to expand the tree-ring network in the Mid-Atlantic Region for both spatial, temporal, and species coverage.

\section{Frequency, intensity, and duration of events}

Annual to multi-decadal variability occurred throughout the reconstructed record (9502001) of Potomac River streamflow and abrupt transitions from dry to wet or wet to dry were common throughout the reconstruction (Fig. 3a). In the Potomac River Basin, drought and pluvial events challenge water resources managers' ability to supply adequate clean water. By further examining the frequency (events per time period), intensity (a value's departure from the median), and duration of events (years below or above the long-term median), water resource 
managers may be better able to integrate reconstructed streamflow into management decisions. Intensity and duration were examined by computing the 10 lowest and highest reconstructed $n$ year running means for $n=1,5,11$, and 25 years (Table 2). The most severe $n$-year events from the instrumental period were calculated for comparison to the reconstructed record of streamflow. Overall, the reconstructed record contained drought events drier than recorded in the instrumental record and pluvial events less wet than observed. The driest single year in the instrumental record (1930) was surpassed only three times in the past millennium. However, the multi-year drought in the 1960s was more severe in the reconstructed record than 1930, ranking in the top 10 driest events in the 1-, 5-, 11-, and 25 -year periods. The late $16^{\text {th }}$ century saw some of the most severe single-year and multi-year drought events that exceeded the intensity of any events in the observed record. The intensity and duration of late $16^{\text {th }}$ century drought events confirmed the existence of the $16^{\text {th }}$ century megadrought recorded in tree-ring proxies of moisture across North America [Stahle et al., 2000, 2007; Woodhouse and Overpeck, 1998]. Additionally, regional drought events of historic significance around the turn of the $16^{\text {th }}$ century (i.e., Roanoke Island and Jamestown droughts) were replicated well in our streamflow reconstruction [Stahle et al., 1998].

Pluvial events of the late $20^{\text {th }}$ century rank among the wettest in the reconstruction but the intensity of these events was underestimated in the model, suggesting that reconstruction was conservative in the representation of extreme wet events. The intensity of late $20^{\text {th }}$ century pluvials confirmed the trend of increased moisture in the Potomac River Basin during the past century [Maxwell et al. submitted; Neff et al., 2000]. The year 1996 was exceptional in the instrumental record because it had two major flooding events of the Potomac River at Harper's Ferry in January and September. While the reconstruction of streamflow did not represent the 
full range of pluvial values in the observed record, the reconstruction suggests that pluvial events up to 25 years in duration may have occurred in the past. The $11^{\text {th }}$ century ranked among the top wettest 1-, 5-, 11-, and 25-year periods, coincident with the Medieval Warm Epoch (900-1300) and the associated increase in PRB moisture during that time [Maxwell et al. submitted]. The $20^{\text {th }}$ century has seen some of the driest and wettest annual to decadal events in the past millennium but longer and more severe events were reconstructed in previous centuries. We examined drought and pluvial event duration and frequency in the reconstructed and instrumental records by counting $n$-year events below or above the median streamflow (Fig. 5). Both the reconstructed and instrumental records show similar counts of 1 to 4 -year droughts and pluvials but the $20^{\text {th }}$ century did not fully represent the frequency of longer event durations that occurred in the reconstruction. While uncommon, the reconstruction contained 7 to 14 year drought and pluvial events that may stress the water supply system beyond levels seen in the observed record.

To highlight the low-frequency trends in the median and variance of the reconstructed record, we created box-and-whisker plots for 50-year periods of the back-transformed proxy record and compared them to the back-transformed instrumental data (1907-2007; Fig. 6). Several observations were made about the low-frequency trends in the reconstruction. First, the median and variance of the back-transformed instrumental record was modeled well suggesting the reconstruction was suitable for evaluation of low-frequency trends. Second, the $20^{\text {th }}$ century had the greatest variability in the past 300 years, confirming previous results in the Potomac River Basin [Maxwell et al. submitted]. Third, the period from 1700-1900 had below median growth and reduced variability compared to the entire reconstruction. The second half of the $19^{\text {th }}$ century was greatly below the long-term median and had the smallest variance of any 50-year period in the reconstruction. Fourth, the period from 1250-1500 was consistently above the 
median with only small fluctuations in variance and few extreme drought or pluvial events. Finally, extreme events (i.e., $<10^{\text {th }}$ and $>90^{\text {th }}$ percentiles) were not evenly distributed over the past millennium.

\section{Comparison to Cook and Jacoby [1983]}

Our mean May-September reconstruction of Potomac River streamflow at Point of Rocks, Maryland (950-2001) was moderately correlated $(r=0.65)$ with Cook and Jacoby's [1983] mean June-August reconstruction of the same streamflow gage (1730-1977). The moderate correlation was likely an effect of: 1) the lengthened season of reconstruction; 2) differences in the reconstruction models; and 3) the increased number of chronologies and species types. Cook and Jacoby originally reconstructed June-August streamflow using canonical regression of five chronologies representing four species to determine the appropriate reconstruction period and model. Our analysis relied on a similar method of principal component analysis of 27 chronologies representing nine species during almost the same time period (1700-1976). We hypothesize that the expanded range of species aided in the lengthening of the seasonal window of reconstruction by taking advantage of the phenological traits of each species and their differential response to growing season climate variability. Additional small differences in the selection of predictor chronologies and the calibration/verification period may have contributed to differences in the reconstructions.

The greatest difference between the reconstructions was the increase in the mean and variance from the previous reconstruction to the present model (Fig. 7). Cook and Jacoby's reconstruction had a $85.9 \mathrm{~m}^{3} / \mathrm{sec}$ mean and $27.8 \mathrm{~m}^{3} / \mathrm{sec}$ standard deviation, while mean and standard deviation of our reconstruction were $132.8 \mathrm{~m}^{3} / \mathrm{sec}$ and $46.0 \mathrm{~m}^{3} / \mathrm{sec}$, respectively. The 
newer model better represents the mean $\left(186.2 \mathrm{~m}^{3} / \mathrm{sec}\right)$ and standard deviation $\left(90.3 \mathrm{~m}^{3} / \mathrm{sec}\right)$ of the untransformed 1907-2007 instrumental record. Extreme pluvial events in the observed record contribute to an instrumental variance greater than triple the Cook and Jacoby reconstruction and double our reconstruction. The reduction in the mean and variance of the reconstructions is at least partly an effect of log transforming the streamflow data prior to modeling. Back-transformed values of streamflow will always have a smaller mean and variance. Despite the differences in the mean and variance of the reconstructions, the records showed similar trends in local variance and duration of events. For example, the 1850-1900 period of below median flow and low variance and the 1900-1950 period of above median flow and high variance were present in each reconstruction. Additionally, the duration of the 1960s drought was replicated in both records. The increased variance in the instrumental period from 1977 to the present, in addition to the decrease in the number of predictor chronologies for the most recent 30+ years, may account for the reduced performance of our reconstruction in the 1700-2001 nested PCR model (Fig. 3). Future modeling efforts may be challenged to reproduce the extreme pluvial events of the past $30+$ years because tree growth is physiologically limited regardless of the increase in available moisture. The Mid-Atlantic Region is predicted to become wetter in the coming decades [Najjar et al., 2000] and the potential divergence of treegrowth/streamflow relationships should be further investigated.

\section{Summary and Conclusions}

Mean May-September Potomac River streamflow was reconstructed from 950-2001 using a network of tree-ring chronologies $(n=27)$ representing nine eastern tree species. We chose a nested PCR model to maximize the number of available predictor chronologies 
backward in time. Our reconstruction model performed well in the common period explaining $52 \%$ of the variance in the calibration period with a $0.25 \mathrm{RE}$ statistic during the verification period. The fluctuation in calibration and verification statistics during the $1550-1700$ period likely was caused by the reduction in sample size in combination with the loss of important predictor species. Surprisingly, C. ovata, M. acuminata, and L. tulipifera were strong predictors of streamflow despite being represented by only one chronology per species. Additional sampling should focus on expanding the tree-ring network in the Mid-Atlantic Region for both spatial, temporal, and species coverage to strengthen the reconstruction during the $16^{\text {th }}$ and $17^{\text {th }}$ centuries. Our reconstruction of mean May-September Potomac River streamflow was a significant improvement to Cook and Jacoby's [1983] streamflow reconstruction because it expanded the seasonal window, lengthened the record by 780 years, and better replicated the mean and variance of the instrumental record.

Knowledge of past drought and pluvial events is important for water resource management in the Potomac River Basin. However, the instrumental record of Potomac River streamflow does not adequately represent the full range of variability in the past millennium as evidenced by our reconstruction of streamflow. Extreme drought and pluvial events ranging from 1-25 years in duration have occurred during the period of the instrumental record but more severe drought events were represented by the reconstruction. Multi-decadal variability in streamflow also must be an important consideration in management practices. Half-century periods of below and above median streamflow were common in the past millennium and may require new strategies to secure the water supply system. Further modeling of streamflow events longer than 50 years may be possible in the Mid-Atlantic Region using millennial-length $J$. virginiana and T. distichum chronologies. With the expanded season of streamflow 
reconstruction, water resource managers may be better prepared to meet water demand and maintain water quality throughout the low-flow season from July-November. Currently, treering reconstruction models have difficulty modeling fall streamflow events but some portion of the variance may be explained with collection of additional sites and species, particularly those species for which the previous year's moisture has a preconditioning effect on growth.

In the coming decades, precipitation and streamflow are projected to increase in the MidAtlantic region, impacting the delivery of adequate and quality water for human use and ecosystem services [Najjar et al., 2000; Neff et al., 2000]. Extreme short-term pluvial events in the observed record of streamflow already have exceeded all reconstructed pluvial events. These positive extremes present difficulty for tree-ring reconstructions because trees are physiologically limited in their uptake of water from storm events and do not track sub-annual high-flow periods well. However, the duration of longer pluvial events was well replicated during the instrumental period. Future work will concentrate on: 1) expanding the temporal, spatial, and species coverage of the tree-ring network in the Mid-Atlantic Region for water resource modeling; 2) reconstructing low-frequency events over the past millennium; 3) strengthening the later period of the low-flow season; and 4) communicating and integrating our results into water management practices and water demand modeling through collaboration with regional water resource managers at the Interstate Commission for the Potomac River Basin.

\section{Acknowledgements}

We would like to thank Rob Wilson and ITRDB contributors for kindly providing their tree-ring data and the Interstate Commission on the Potomac River Basin for providing streamflow data. Funding for the project was provided by the NASA West Virginia Space Grant 
Consortium, West Virginia University Eberly College of Arts and Sciences, and the National Science Foundation grant \#0925114.

\section{References}

Akaike, H. (1974), A new look at the statistical model identification, IEEE Transactions on Automatic Control, 19, 716-723.

Akkemik, U., R. D'Arrigo, P. Cherubini, N. Kose, and G. Jacoby (2008), Tree-ring reconstructions of precipitation and streamflow for north-western Turkey, International Journal of Climatology, 28.

Box, G., and G. Jenkins (1970), Time Series Analysis: Forecasting and Control, Holden-Day.

Briffa, K. (1984), Tree-climate relationships and dendrochronological reconstruction in the British Isles. Ph.D. Dissertation, University of East Anglia, 525 p.,

Brooks, A. (1910), Forestry and Wood Industries, West Virginia Geological Survey, Acme Publishing Company.

Cook, E. (1985), A time series analysis approach to tree-ring standardization. Ph.D. Dissertation, University of Arizona, Tuscon. 171 p.,

Cook, E., K. Briffa, and P. Jones (1994), Spatial regression methods in dendroclimatology: a review and comparison of two techniques, International Journal of Climatology, 14, 379402.

Cook, E., K. Briffa, D. Meko, D. Graybill, and G. Funkhouser (1995), The 'segment length curse' in long tree-ring chronology development for paleoclimatic studies, The Holocene, 5 , 229-237.

Cook, E., R. D'Arrigo, and M. Mann (2002), A well-verified, multiproxy reconstruction of the winter North Atlantic Oscillation index since A.D. 1400, Journal of Climate, 15, 17541764.

Cook, E., and G. Jacoby (1977), Tree-ring drought relationships in the Hudson Valley, New York, Science, 198, 399-401.

Cook, E., and G. Jacoby (1983), Potomac River streamflow since 1730 as reconstructed by tree rings, Journal of Climate and Applied Meteorology, 22, 1659-1672.

Cook, E., D. Meko, D. Stahle, and M. Cleaveland (1999), Drought reconstructions for the continental United States, Journal of Climate, 12, 1145-1162. 
Frank, D., and J. Esper (2005), Temperature reconstructions and comparisons with instrumental data from a tree-ring network for the European Alps, International Journal of Climatology, 25, 1437-1454.

Fritts, H. (1976), Tree Rings and Climate, Academic Press, New York, NY.

International Tree-Ring Data Bank (2010), ICBP PAGES/World Data Center for Paleoclimatology, NOAA/NCDC Paleoclimatology Program, Boulder, Colorado, USA,

Kame'enui, A., E. Hagen, and J. Kiang (2005), Water supply reliability forecast for the Washington, DC metropolitan area year 2025, Interstate Commission on the Potomac River Basin, Report No. 05-06.

Lorie, M., and E. Hagen (2007), Placing Potomac River droughts in context using synthetic and paleoclimatic data, in World Environmental and Water Resources Congress 2007: Restoring Our Natural Habitat.

Lull, H., and W. Sopper (1966), Factors that influence streamflow in the northeast, Water Resources Research, 2, 371-379.

Maxwell, R., A. Hessl, and E. Cook, A 1248-year reconstruction of May precipitation for the Mid-Atlantic Region using Juniperus virginiana tree rings, Journal of Climate.

Meko, D., C. Stockton, and W. Boggess (1995), Tree-ring record of severe sustained drought, Water Resources Bulletin, 31, 789-901.

Meko, D., M. Therrell, C. Baisan, and M. Hughes (2001), Sacremento River flow reconstructed to A.D. 869 from tree rings, Journal of the American Water Resources Association, 37, 1029-1039.

Najjar, R. et al. (2000), The potential impacts of climate change on the mid-Atlantic coastal region, Climate Research, 14, 219-233.

Neff, R., H. Chang, G. Knight, R. Najjar, B. Yarnal, and H. Walker (2000), Impact of climate variation and change on mid-atlantic region hydrology and water resources, Climate Research, 14, 207-218.

Osborn, T. J., K. Briffa, and P. Jones (1997), Adjusting variance for sample-size in tree-ring chronologies and other regional mean time series, Dendrochronologia, 15, 89-99.

Patric, J., and K. Reinhart (1971), Hydrologic effects of deforesting two mountain watersheds in West Virginia, Water Resources Research, (7), 1182-1188.

Pederson, N., G. Jacoby, R. D'Arrigo, E. Cook, and B. Buckley (2001), Hydrometeorological reconstructions from northeastern Mongolia derived from tree rings: 1651-1995, Journal 
of Climate, 14.

Polsky, C., J. Allard, N. Currit, R. Crane, and B. Yarnal (2000), The Mid-Atlantic region and its climate: past, present, and future, Climate Research, 14, 161-173.

Rice, J., C. Woodhouse, and J. Lukas (2009), Science and decision making: water management and tree-ring data in the western United States, Journal of the American Water Resources Association, 45, 1248-1259.

Stahle, D., M. Cleaveland, D. Blanton, M. Therrell, and D. Gay (1998), The lost colony and Jamestown droughts, Science, 280, 564-567.

Stahle, D., E. Cook, M. Cleaveland, M. Therrell, D. Meko, H. Grissino-Mayer, E. Watson, and B. Luckman (2000), Tree-ring data document 16th century megadrought over North America, Eos Transactions AGU, 81(12), 121.

Stahle, D., F. Fye, E. Cook, and R. Griffin (2007), Tree-ring reconstructed megadroughts over North America since A.D. 1300, Climatic Change, 83, 133-149.

United States Geological Survey (2010), Gage \#01638500, Potomac River at Point of Rocks, Maryland, [online] Available from:

http://waterdata.usgs.gov/md/nwis/uv?site_no=01638500

Wigley, T., K. Briffa, and P. Jones (1984), On the average value of correlated time series, with applications in dendroclimatology and hydrometeorology, Journal of Applied Meteorology, 23, 201-213.

Woodhouse, C., S. Gray, and D. Meko (2006), Updated streamflow reconstructions for the Upper Colorado River Basin, Water Resources Research, 42, W05415, doi:10.1029/2005WR004455.

Woodhouse, C., and J. Lukas (2006a), Drought, tree rings and water resource management in Colorado, Canadian Water Resources Journal, 31, 1-14.

Woodhouse, C., and J. Lukas (2006b), Multi-century tree-ring reconstructions of Colorado streamflow for water resource planning, Climatic Change, 78, 293-315.

Woodhouse, C., and J. Overpeck (1998), 2000 years of drought variability in the central United States, Bulletin of the American Meteorological Society, 79, 2693-2714. 


\section{Tables}

TABLE 1. Chronologies used in the Potomac River streamflow reconstruction.

\begin{tabular}{|c|c|c|c|c|c|c|c|}
\hline Site Name & Investigator & Species $^{*}$ & $\begin{array}{l}\text { No. } \\
\text { Series** }\end{array}$ & Period & $\begin{array}{l}\text { Median } \\
\text { Length }\end{array}$ & Lat. $\mathbf{N}$ & Long. W \\
\hline Blue Ridge Parkway & Pederson, $\mathrm{N}$. & QUPR & 55 & $1590-2002$ & 265 & 37.740 & -79.710 \\
\hline Cedar Knob & Wilson, R. & JUVI & 43 & $1660-2000$ & 212 & 38.657 & -79.379 \\
\hline Cedar Knob & Cook, E.R. & JUVI & 152 & 481-1998 & 267 & 38.657 & -79.379 \\
\hline Fiddler's Green & Pederson, N. & CAOV & 28 & $1650-2002$ & 175 & 37.830 & -79.370 \\
\hline Fiddler's Green & Pederson, N. & LITU & 31 & $1668-2002$ & 218 & 37.810 & -79.370 \\
\hline Fiddler's Green & Pederson, N. & MAAC & 16 & $1656-2002$ & 169 & 37.800 & -79.380 \\
\hline Irish Creek & Pederson, N., Cook, E.R. & QUPR & 21 & $1594-2002$ & 239 & 37.800 & -79.300 \\
\hline Otter Creek Natural Area & Pederson, N., Cook, E.R. & QUPR & 39 & $1578-2003$ & 201 & 40.060 & -76.460 \\
\hline Alan Seeger Natural Area & Cook, E.R. & TSCA & 24 & $1609-1981$ & 308 & 40.667 & -77.700 \\
\hline Bear Run & Cook, E.R. & TSCA & 19 & $1641-1981$ & 244 & 40.883 & -77.317 \\
\hline Hemlocks Natural Area & Cook, E.R. & TSCA & 26 & $1535-1981$ & 273 & 40.233 & -77.650 \\
\hline Sweetroot Natural Area & Cook, E.R. & TSCA & 25 & $1612-1981$ & 262 & 39.833 & -78.517 \\
\hline Patty's Oaks & Pederson, N., Cook, E.R. & QUAL & 52 & $1520-2002$ & 289 & 37.917 & -79.800 \\
\hline Savage River State Forest & Pederson, $\mathrm{N}$. & QUAL & 29 & $1646-2003$ & 265 & 39.520 & -79.280 \\
\hline Savage River State Forest & Pederson, N. & QUPR & 48 & $1630-2003$ & 216 & 39.560 & -79.340 \\
\hline Smoke Hole & Maxwell, R.S., Wixom, J.A. & JUVI & 128 & $517-2007$ & 359 & 38.828 & -79.288 \\
\hline Hemlock Cove & Cook, E.R. & TSCA & 37 & $1531-1982$ & 263 & 37.500 & -79.517 \\
\hline Mountain Lake & Cook, E.R. & QUAL & 26 & $1552-1983$ & 285 & 37.383 & -80.500 \\
\hline Mountain Lake & Cook, E.R. & PCRU & 38 & 1694-1982 & 214 & 37.383 & -80.500 \\
\hline Pinnacle Point & Cook, E.R. & QUAL & 25 & $1612-1981$ & 293 & 38.500 & -78.350 \\
\hline Ramsey's Draft & Cook, E.R. & TSCA & 23 & $1595-1981$ & 254 & 38.333 & -79.333 \\
\hline Massenhutten Mountain & Cook, E.R. & QUPR & 25 & $1642-1981$ & 255 & 38.500 & -78.350 \\
\hline Blackwater River & $\begin{array}{l}\text { Stahle, D.W., Cleaveland, } \\
\text { M.K., Hehr, J.G. }\end{array}$ & TADI & 73 & $932-1985$ & 376 & 36.783 & -76.883 \\
\hline Chickahominy River & $\begin{array}{l}\text { Stahle, D.W., Cleaveland, } \\
\text { M.K. }\end{array}$ & TADI & 13 & $1662-1984$ & 197 & 37.383 & -76.933 \\
\hline Dragon Run & $\begin{array}{l}\text { Stahle, D.W., Cleaveland, } \\
\text { M.K., Hehr, J.G. }\end{array}$ & TADI & 17 & $1372-1984$ & 228 & 37.617 & -76.667 \\
\hline Nottoway River & $\begin{array}{l}\text { Stahle, D.W., Cleaveland, } \\
\text { M.K. }\end{array}$ & TADI & 49 & $1171-1984$ & 291 & 36.783 & -77.133 \\
\hline Gaudimeer Scenic Area & Cook, E.R. & PCRU & 22 & $1614-1977$ & 228 & 38.420 & -79.500 \\
\hline
\end{tabular}

$*$ CAOV $=$ Carya ovata $;$ JUVI = Juniperus virginiana $;$ LITU = Liriodendron tulipifera $;$ MAAC

= Magnolia acuminata $; \mathrm{PCRU}=$ Picea rubens; $\mathrm{QUAL}=$ Quercus alba $;$ QUPR = Quercus

prinus $;$ TADI $=$ Taxodium distichum $;$ TSCA $=$ Tsuga canadensis .

**Number of series and median series length were calculated following removal of series shorter than 125 years. 
TABLE 2. Lowest $n$-year moving averages of the reconstructed (950-2001) and actual streamflow.*

\begin{tabular}{|c|c|c|c|c|c|c|c|c|}
\hline \multicolumn{5}{|l|}{ Droughts } & \multicolumn{4}{|l|}{ Pluvials } \\
\hline Rank & 1 Year & 5 Year & 11 Year & 25 year & 1 Year & 5 Year & 11 Year & 25 year \\
\hline 1 & $33.8(1586)$ & 70.1 (1597) & $92.0(1627)$ & $107.0(1036)$ & $394.3(1672)$ & $241.7(1088)$ & $195.0(1090)$ & $176.4(1094)$ \\
\hline 2 & 43.7 (1774) & 80.0 (1964) & 92.4 (1594) & $107.7(1634)$ & 334.0 (1949) & $222.4(1751)$ & $186.2(1656)$ & $164.1(1660)$ \\
\hline 4 & 48.8 (1334) & $84.6(1985)$ & $97.1(1042)$ & $114.0(1698)$ & $320.5(1021)$ & $204.8(1056)$ & $177.2(1617)$ & $161.7(1747)$ \\
\hline 5 & $52.7(1747)$ & $87.2(980)$ & $100.9(1964)$ & $114.7(1779)$ & $316.8(1753)$ & $204.1(1752)$ & $176.8(1432)$ & 160.5 \\
\hline 6 & $52.8(1598)$ & $87.3(1624)$ & $101.0(1254)$ & $115.4(1853)$ & 304.6 (1333) & $202.0(1582)$ & $173.5(1101)$ & 160.0 \\
\hline 7 & $53.3(1438)$ & 87.7 (1587) & $105.4(1778)$ & $117.3(1598)$ & $295.0(1121)$ & $201.6(1019)$ & $173.2(1995)$ & $158.5(1946)$ \\
\hline 8 & $53.4(1235)$ & $88.6(1210)$ & $106.4(982)$ & $117.5(1563)$ & $290.9(1086)$ & $198.7(1120)$ & $172.8(1243)$ & $158.0(960)$ \\
\hline 9 & $53.8(1164)$ & $90.3(1630)$ & $106.9(1847)$ & $117.5(1975)$ & $290.9(1362)$ & 197.5 (1737) & $172.1(1016)$ & $154.7(1337)$ \\
\hline 10 & $55.7(1597)$ & $91.2(1701)$ & $107.1(1212)$ & 117.6 (1409) & $288.3(1297)$ & 197.3 (1659) & $171.6(1295)$ & $154.3(1612)$ \\
\hline Actual & $46.5(1930)$ & $100.4(1964)$ & 132.7 (1964) & $161.3(1957)$ & 575.9 (1996) & 286.1 (1973) & 237.0 (1999) & $215.2(1983)$ \\
\hline
\end{tabular}

*Events are non-overlapping averages of the mean May-September Potomac River streamflow $\left(\mathrm{m}^{3} / \mathrm{sec}\right)$ for $n$-year periods with the center year in parentheses. Rows 1-10 are the most severe reconstructed events and the last row is the most severe observed (actual) event. 


\section{List of Figures}

FIG. 1. Maps show the location of 27 tree-ring sites used as predictors in the reconstruction. Sites are differentiated by species (in the left panel) and by beta weights for all chronologies used in the common period 1700-1976 (in the right panel). The beta weights represent the explanatory power of the chronologies. The 0 loading for the TSCA chronology was rounded down from 0.48. See text for details on beta weight calculation. For species codes, see Table 1. The shaded area is the Potomac River Basin.

FIG. 2. Monthly Potomac River streamflow at Point of Rocks, Maryland calculated from 18952007 data. The highlighted portion represents the time period when demand may exceed streamflow necessitating augmentation by reserviors.

FIG. 3. (a) The reconstruction of mean May-September Potomac River streamflow and the number of predictor chronologies, and (b) the time-varying calibration and verification statistics for nested PCR models from 950-2001. The reconstruction was smoothed with a 10-year $4^{\text {th }}$ order spline to highlight decadal trends.

FIG. 4. Nested PCR models (gray lines) during the calibration and verification period. Only nested models from the 950-2001 period are shown. The 1700-1976 model (black dotted line) and the instrumental record of streamflow (solid black line) are presented for comparison.

FIG. 5. Histograms showing the frequency of $n$-year drought and pluvial events (years below or above the median streamflow) for the (a) reconstruction and (b) instrumental period.

FIG. 6. Box-and-whisker plots $\left(10^{\text {th }}, 25^{\text {th }}, 50^{\text {th }}, 75^{\text {th }}\right.$, and $90^{\text {th }}$ percentiles $)$ were calculated for each half century of the back-transformed streamflow reconstruction and the back-transformed instrumental period (1907-2007). Dashed gray lines represent the $10^{\text {th }}, 50^{\text {th }}$, and $90^{\text {th }}$ percentiles calculated using the entire reconstruction (950-2001) for comparison.

FIG. 7. Comparison of the May-September reconstruction of Potomac River streamflow (blue line; current study), Cook and Jacoby's previous June-August reconstruction of the same streamflow gage (red line), and the actual untransformed streamflow record. The dashed lines represent the mean streamflow for each record. 
Figures with Captions
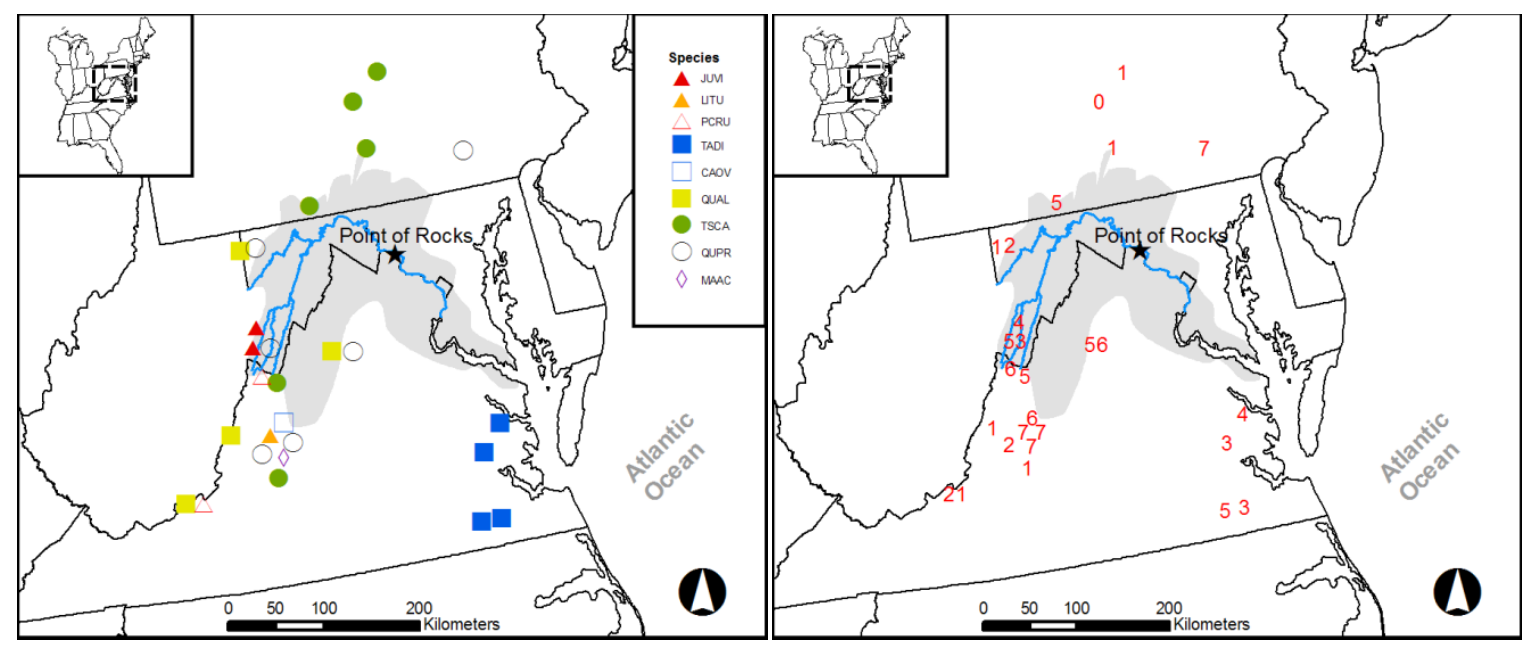

FIG. 1. Maps show the location of 27 tree-ring sites used as predictors in the reconstruction. Sites are differentiated by species (in the left panel) and by beta weights for all chronologies used in the common period 1700-1976 (in the right panel). The beta weights represent the explanatory power of the chronologies. The 0 loading for the TSCA chronology was rounded down from 0.48. See text for details on beta weight calculation. For species codes, see Table 1. The shaded area is the Potomac River Basin.

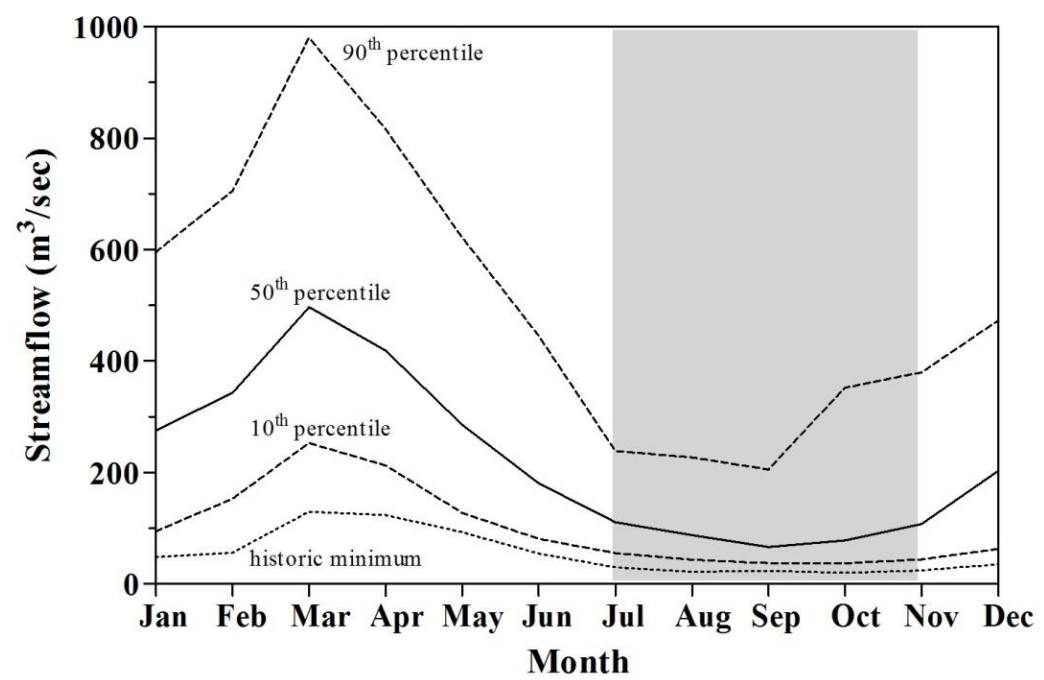

FIG. 2. Monthly Potomac River streamflow at Point of Rocks, Maryland calculated from 18952007 data. The highlighted portion represents the time period when demand may exceed streamflow necessitating augmentation by reserviors. 


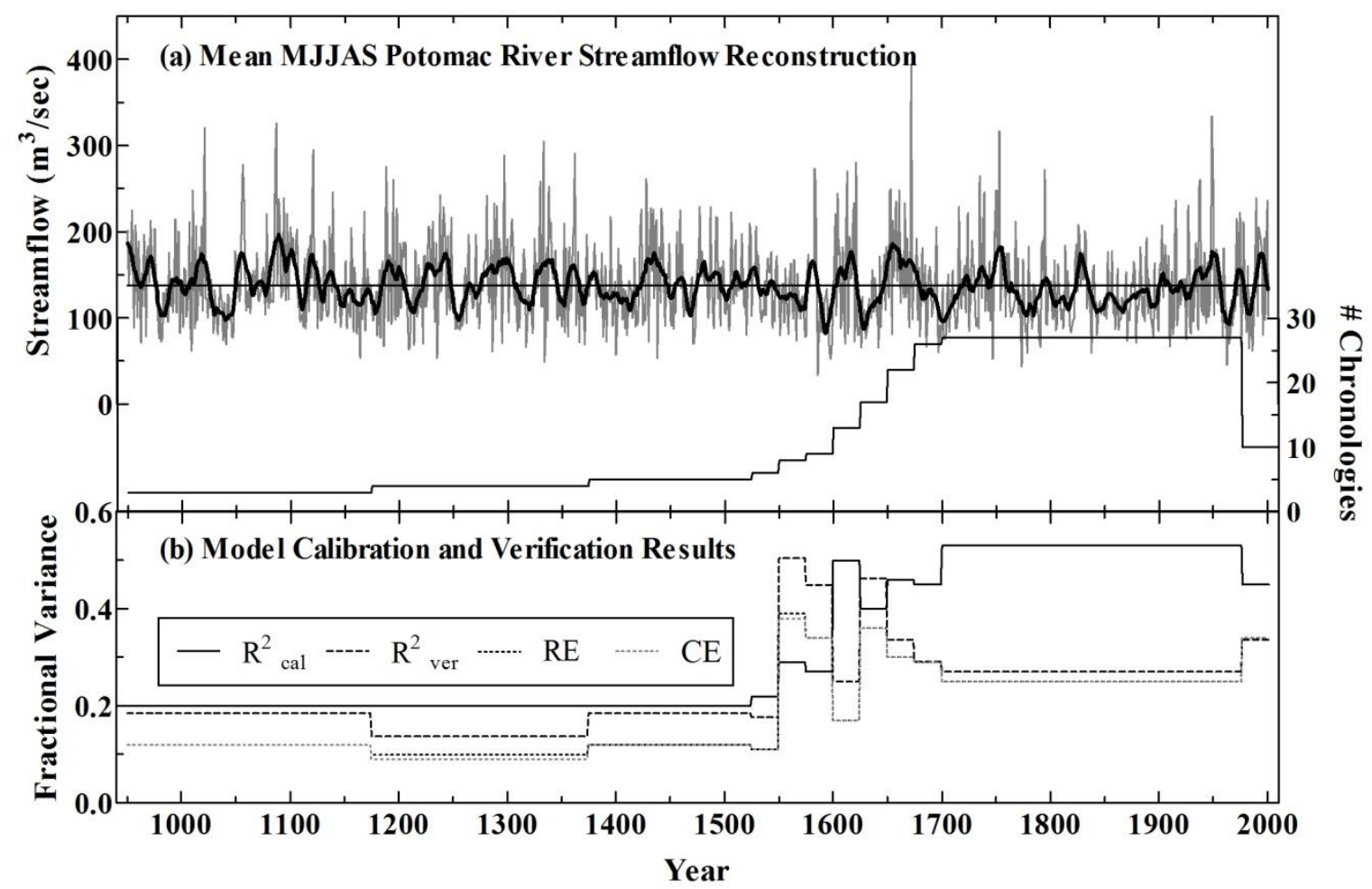

FIG. 3. (a) The reconstruction of mean May-September Potomac River streamflow and the number of predictor chronologies, and (b) the time-varying calibration and verification statistics for nested PCR models from 950-2001. The reconstruction was smoothed with a 10 -year $4^{\text {th }}$ order spline to highlight decadal trends.

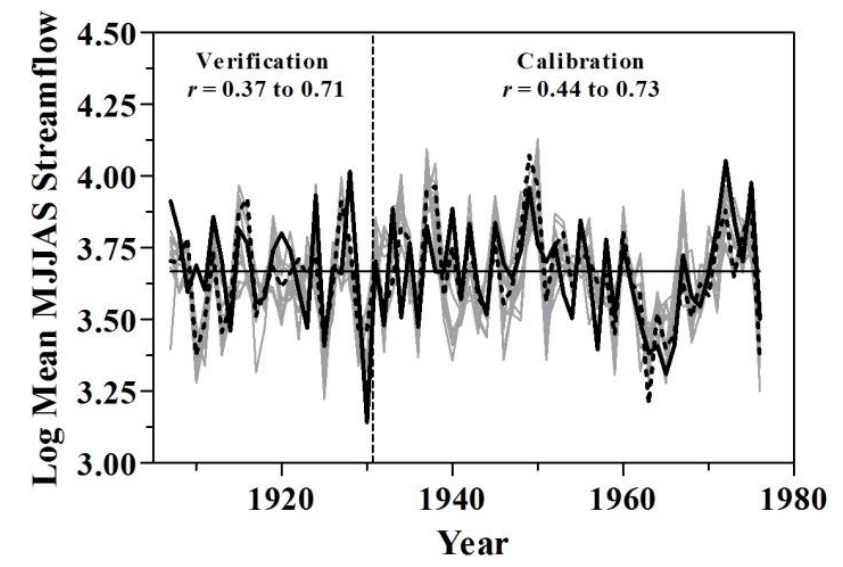

FIG. 4. Nested PCR models (gray lines) during the calibration and verification period. Only nested models from the 950-2001 period are shown. The 1700-1976 model (black dotted line) and the instrumental record of streamflow (solid black line) are presented for comparison. 


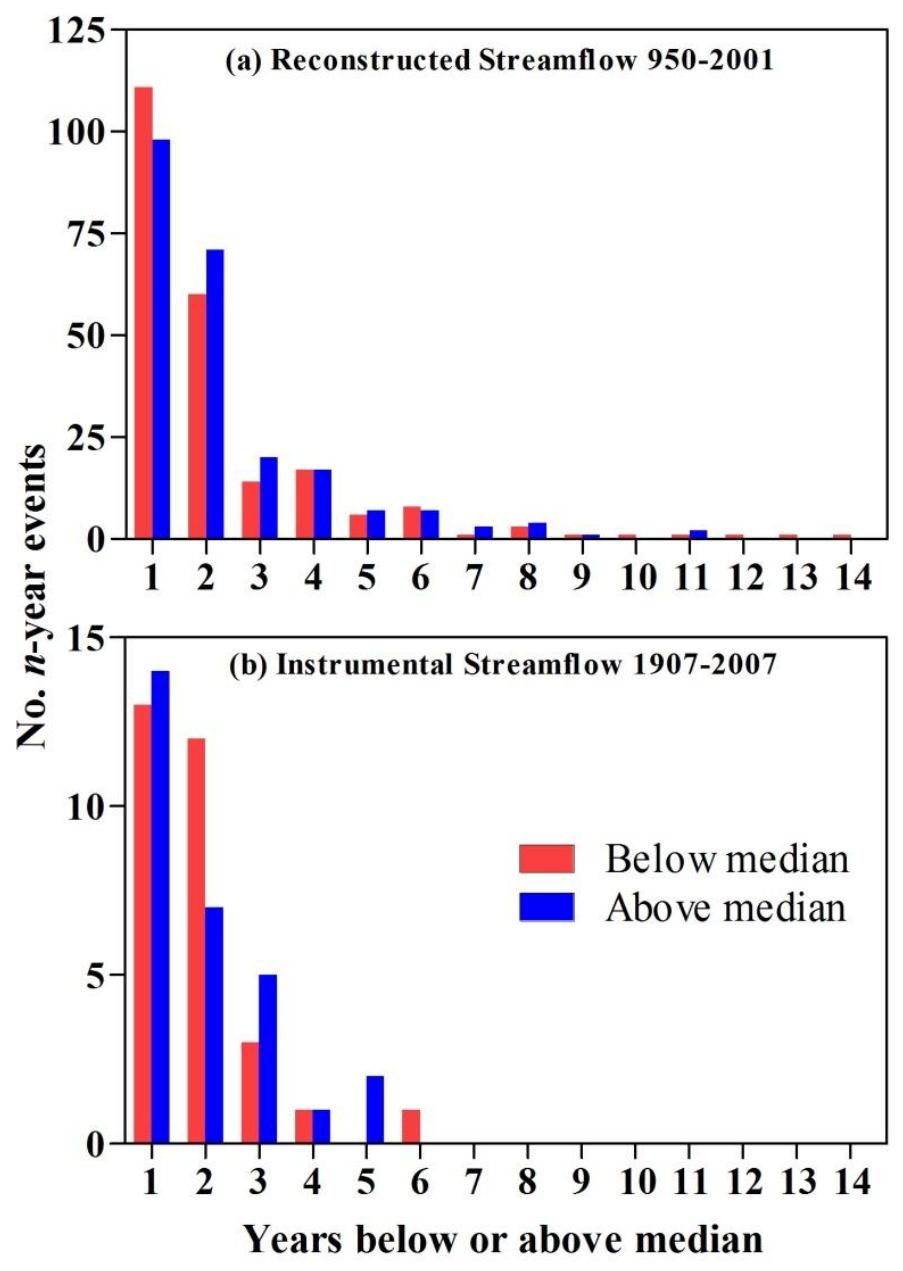

FIG. 5. Histograms showing the frequency of $n$-year drought and pluvial events (years below or above the median streamflow) for the (a) reconstruction and (b) instrumental period. 


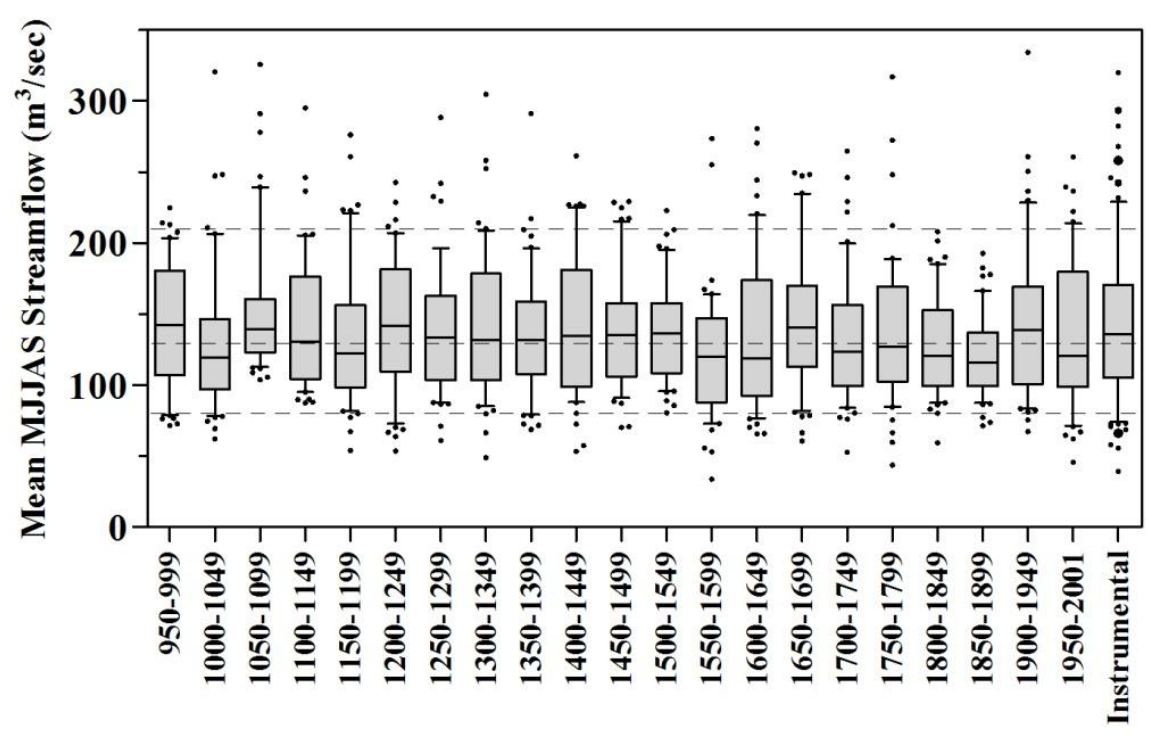

\section{Period}

FIG. 6. Box-and-whisker plots $\left(10^{\text {th }}, 25^{\text {th }}, 50^{\text {th }}, 75^{\text {th }}\right.$, and $90^{\text {th }}$ percentiles $)$ were calculated for each half century of the back-transformed streamflow reconstruction and the back-transformed instrumental period (1907-2007). Dashed gray lines represent the $10^{\text {th }}, 50^{\text {th }}$, and $90^{\text {th }}$ percentiles calculated using the entire reconstruction (950-2001) for comparison.

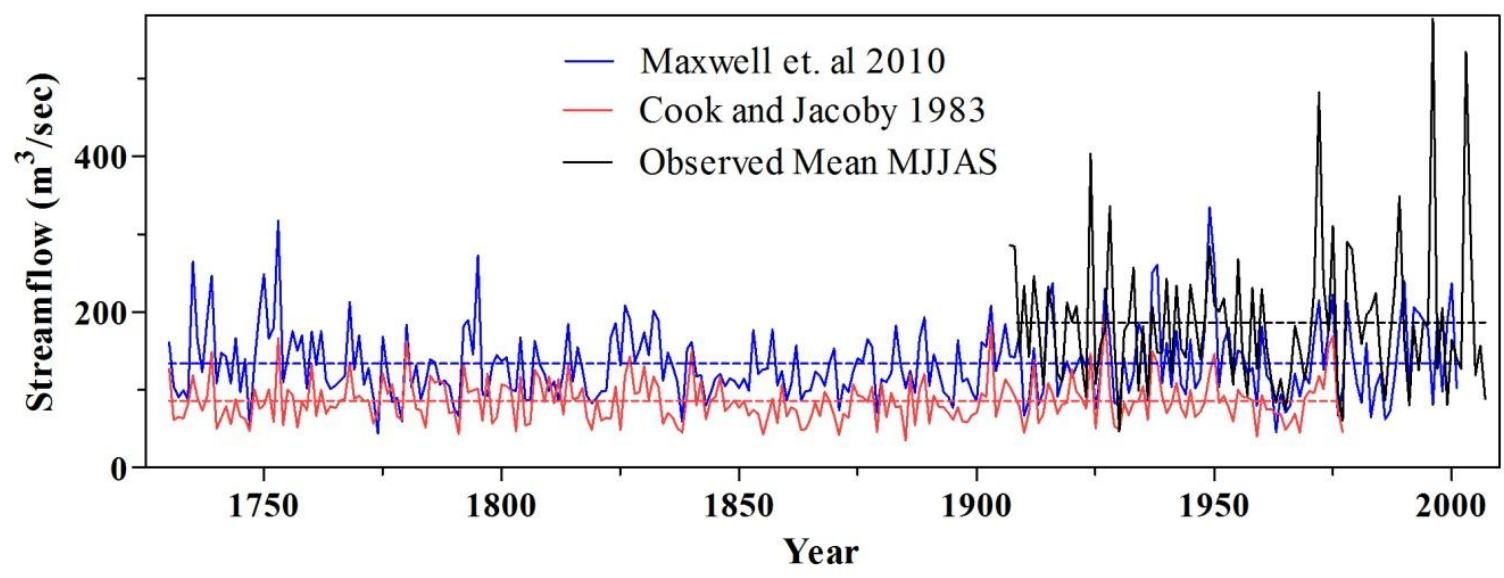

FIG. 7. Comparison of the May-September reconstruction of Potomac River streamflow (blue line; current study), Cook and Jacoby's previous June-August reconstruction of the same streamflow gage (red line), and the actual untransformed streamflow record. The dashed lines represent the mean streamflow for each record. 


\section{Summary}

We recognize that eastern redcedar is a difficult species to crossdate, regardless of technique, because of the prevalence of false, missing, and micro-rings. We could have experimented further with the EW-LW boundary definition in the WinDENDRO system to aid technicians in the measurement process. Additionally, a set of well-defined rules for the amount of allowable boundary manipulation could be developed in future work. Based on our analysis, total-width measurements of eastern redcedar are acceptable to combine across measurement and crossdating systems even for species with narrow, false, or micro-rings. However, WinDENDRO measurements (and crossdating) are only acceptable if questionable annual rings are verified with a stereoscope. The use of latewood widths across techniques and technicians for eastern redcedar resulted in significant differences in correlations with climate variables, suggesting that latewood widths are not suitable for further dendroclimatic analysis.

For species with common growth anomalies and narrow rings, the Velmex system is preferable because individual cells can be seen clearly under magnification. Perhaps, future computing and imaging technologies will allow individual cells to be visible in WinDENDRO without the interpolation of scanned images and the burden of large file sizes slowing image manipulation. Image size and dpi will become less of a limitation as imaging and computing technology progresses. In the future, we suggest the development of a rigorous standardized definition for the EW-LW boundary in both measurement and crossdating systems.

Over the past century, the MAR has received an increasing amount of precipitation $(\sim 0.23 \mathrm{~mm} / \mathrm{yr})$. Climate models project that this trend likely will continue coincident with increasing regional temperatures (Polsky et al. 2000). Expected regional changes in climate will affect water quantity and quality and impact urban populations and ecosystem services. The 
dearth of multi-century to millennial-length proxy records of climate in the eastern United States has made the evaluation of current and future changes in the MAR climate difficult. In our study, two millennial-length eastern redcedar chronologies have been used to reconstruct May precipitation for the MAR of the United States. The calibration model explained 32\% of the variance in the instrumental record from $\mathrm{AD}$ 1895-1945. The model was well verified (AD 1946-1998) by the reduction of error $(\mathrm{RE}=0.33)$ and coefficient of efficiency $(\mathrm{CE}=0.30)$ statistics. Similar to most tree-ring reconstructions, the proxy record did not capture the full range of variability in the instrumental record. Calibration and verification statistics for our reconstruction model were comparable to other single-species reconstructions (Stahle et al. 1988, 1998; Buckley et al. 2004) for the eastern United States.

Mean May-September Potomac River streamflow was reconstructed from 950-2001 using a network of tree-ring chronologies $(n=27)$ representing nine eastern tree species. We chose a nested PCR model to maximize the number of available predictor chronologies backward in time. Our reconstruction model performed well in the common period explaining $52 \%$ of the variance in the calibration period with a $0.25 \mathrm{RE}$ statistic during the verification period. The fluctuation in calibration and verification statistics during the 1550-1700 period likely was caused by the reduction in sample size in combination with the loss of important predictor species. Surprisingly, C. ovata, M. acuminata, and L. tulipifera were strong predictors of streamflow despite being represented by only one chronology per species. Additional sampling should focus on expanding the tree-ring network in the Mid-Atlantic Region for both spatial, temporal, and species coverage to strengthen the reconstruction during the $16^{\text {th }}$ and $17^{\text {th }}$ centuries. Our reconstruction of mean May-September Potomac River streamflow was a significant improvement to Cook and Jacoby's [1983] streamflow reconstruction because it 
expanded the seasonal window, lengthened the record by 780 years, and better replicated the mean and variance of the instrumental record.

In the coming decades, precipitation and streamflow are projected to increase in the MidAtlantic region, impacting the delivery of adequate and quality water for human use and ecosystem services [Najjar et al., 2000; Neff et al., 2000]. Extreme short-term pluvial events in the observed record of streamflow already have exceeded all reconstructed pluvial events. These positive extremes present difficulty for tree-ring reconstructions because trees are physiological limited in their uptake of water from storm events and do not track sub-annual high-flow periods well. However, the duration of longer pluvial events was well replicated during the instrumental period. Future work will concentrate on: 1) expanding the temporal, spatial, and species coverage of the tree-ring network in the Mid-Atlantic Region for water resource modeling; 2) reconstructing low-frequency events over the past millennium; 3) strengthening the later period of the low-flow season; and 4) communicating and integrating our results into water management practices and water demand modeling through collaboration with regional water resource managers at the Interstate Commission for the Potomac River Basin. 


\section{Curriculum Vitae}

\section{Richard Stockton Maxwell}

Department of Geology and Geography

West Virginia University

98 Beechurst Avenue

Morgantown, WV 26506-6300

\section{$\underline{\text { Education }}$}

Ph.D. Geography

M.S. Forest Ecology, summa cum laude

B.A. Psychology, summa cum laude
Phone: 304-280-8565

Fax: 304-293-6522

Email: stockton.maxwell@gmail.com

\section{Professional Experience}

2010- $\quad$ Post Doctoral Research Associate, Department of Geography, The Pennsylvania State University

2009-2010 Graduate Teaching Assistant, Department of Geology and Geography, West Virginia University

2009 Instructor (Summer), Department of Geology and Geography, West Virginia University

2007-2009 Graduate Research Fellow, NASA West Virginia Space Grant Consortium,

2007 Instructor (Fall), Department of Geology and Geography, West Virginia University

2006-2007 Graduate Teaching Assistant, Department of Geology and Geography, West Virginia University

2005-2006 Graduate Research Assistant, Division of Forestry and Natural Resources, West Virginia University

2005-2006 Research Collaborator, National Park Service

2003-2004 Research Assistant, Department of Psychiatry, Temple University

2000-2002 Undergraduate Research Assistant, Department of Psychology, West Virginia University

\section{$\underline{\text { Peer-reviewed Publications }}$}

Maxwell, R.S. and Hicks, R.R. In press. Fire history of a rimrock pine community at New River Gorge National River, West Virginia. Natural Areas Journal.

Spiga, R., Maxwell, R.S., Meisch, R.A., and Grabowski, J. 2005. Human methadone selfadministration and the generalized matching law. The Psychological Record 55: 525-538.

\section{Manuscripts in Progress}


Maxwell, R.S., Hessl, A.E., and Cook, E.R. In preparation. A 1248-year reconstruction of May precipitation for the Mid-Atlantic Region using Juniperus virginiana tree rings. Journal of Climate.

Maxwell, R.S., Cook, E.R., Pederson, N., and Hessl, A.E. In preparation. A Multi-Species TreeRing Reconstruction of Potomac River Streamflow (950-2001). Water Resources Research.

Maxwell, R.S., Wixom, J.A., and Hessl, A.E. Submitted. A comparison of two techniques for measuring and crossdating tree rings. Dendrochronologia.

\section{Other Publications}

Maxwell, R.S., Clark, P., et al. 2009. Reconstructing climate history from cliffside Pinus resinosa on Rattlesnake Mountain, Rumney, New Hampshire. $19^{\text {th }}$ North American Dendroecological Fieldweek.

Gedalof, Z., Maxwell, R.S., Clark, P., et al. 2008. Tree-ring response to climate on the Fraser Plateau, British Columbia. $18^{\text {th }}$ North American Dendroecological Fieldweek.

Maxwell, R.S. and Hicks, R.R. 2007. Rimrock pine communities at New River Gorge National River, West Virginia. Technical Report NPS/NER/NRTR_-2007/081. National Park Service. Philadelphia, PA.

Van de Gevel, S., Maxwell, R.S., et al. 2005. Field sampling and dendrochronological techniques in mixed conifer forests: A comparative study of Ponderosa State Park and French Creek Road, central Idaho. $15^{\text {th }}$ North American Dendroecological Fieldweek.

Maxwell, R.S. 2002. Experimenters as social discriminative stimuli. Honors Thesis. Department of Psychology, West Virginia University.

\section{$\underline{\text { Paper Presentations }}$}

Maxwell, R.S., Cook, E.R., Pederson, N., and Hessl, A.E. A Multi-Species Tree-Ring Reconstruction of Potomac River Streamflow (950-2001). Association of American Geographers Annual Meeting. Washington, D.C.

Maxwell, R.S., Wixom, J.A., and Hessl, A.E. 2009. The trials and tribulations of dating eastern redcedar. Association of American Geographers Annual Meeting. Las Vegas, NV.

Clark, P., Maxwell, R.S., Gedalof, Z., Au, R., Blundon, B., Carnwath, G., Kane, J., Lapp, S., Morena, M., Tjoelker, M., and Vanstone, J. 2009. Tree-ring response to climate on the Fraser Plateau, British Columbia. Association of American Geographers Annual Meeting. Las Vegas, NV.

Hessl, A.E., Brown, P., Maxwell, R.S., Nachin, B., Pederson, N., and Saladyga, T. 2009. Fire, climate, and land use in Mongolia: 400+ Years of Change. Association of American Geographers Annual Meeting. Las Vegas, NV.

Maxwell, R.S., Nachin, B., Hessl, A., Pederson, N., and Brown, P. 2008. The Influence of climate and human land use on fire history near Ulaanbaatar, Mongolia. Association of American Geographers Annual Meeting. Boston, MA.

Hessl, A.E., Maxwell, R.S., Cook, E.R., and Buckley, B. 2007. Eastern redcedar (Juniperus virginiana): Millennial length tree ring records of the mid-Atlantic region? Association of American Geographers Annual Meeting. San Francisco, CA. 
Maxwell, R.S. and Hicks, R.R. 2007. Rimrock pine communities at New River Gorge National River, West Virginia. New River Symposium. Radford, VA.

Maxwell, R.S. and Hicks, R.R. 2006. Fire on the rimrock. Southeastern Division of the Association of American Geographers Annual Meeting. Morgantown, WV.

\section{Poster Presentations}

Maxwell, R.S. and Hicks, R.R. 2006. Rimrock pine communities: a descriptive study. Society of American Foresters Annual Conference. Pittsburgh, PA.

Maxwell, R.S. and Hicks, R.R. 2005. Establishing a historic benchmark for rimrock pine communities at the New River Gorge National River, West Virginia. Davis College of Agriculture, Forestry, and Consumer Sciences Ninth Annual Graduate Student Research Conference. West Virginia University, Morgantown, WV.

Maxwell, R.S., Spiga, R., Meisch, R., and Grabowski, J. 2004. Human methadone selfadministration and the generalized matching law. Association for Behavior Analysis International Conference. Boston, MA.

Maxwell, R.S. and Spiga, R. 2004. Methadone-maintained patients prefer a methadone/ benzodiazepine combinations to either drug alone. Association for Behavior Analysis International Conference. Boston, MA.

Maxwell, R.S. and Doughty, A.H. 2001. Preference for variability in pigeons. Eberly College of Arts and Sciences Research Fair. West Virginia University, Morgantown, WV.

\section{Competitive Research and Educational Funding}

2010 Maxwell, R.S. Dissertation Fellowship, West Virginia University $(\$ 6,000)$

2009-2011 Maxwell, R.S. and Hessl, A.E. Doctoral Dissertation Research: Hydroclimate Reconstructions of the Potomac River Basin Using Tree Rings, National Science Foundation $(\$ 11,983)$

2008-2011 Pederson, N., Hessl, A.E., and Brown, P.M. (Maxwell, R.S., Collaborating Author) Fire, Climate, and Forest History in Mongolia, National Science Foundation $(\$ 423,136)$

2008-2010 Smalldone, D., Hessl, A.E., and Kite, S. (Maxwell, R.S., Collaborating Author) A Comprehensive Assessment of Natural Resources and Visitor Impacts to Cliff Habitats in the New River Gorge National River, including development of a Cliff Resource Management Plan, National Park Service $(\$ 98,052)$

2008-2010 Hessl, A.E. and Thomas, R. (Maxwell, R.S., Collaborating Author) A Climatological and Ecophysiological Investigation of Old-growth Eastern Redcedar, West Virginia University Eberly College of Arts and Science Institutional Grant $(\$ 50,000)$

2008-2009 Hessl, A.E. (Maxwell, R.S., Collaborating Author) Reconstructed Potomac River Flow from Eastern Redcedar Tree Rings (1000 - 2007 AD), West Virginia University Faculty Senate Research Grant $(\$ 10,117)$

2007-2010 Maxwell, R.S. Eberly College of Arts and Sciences Doctoral Student Travel Grant, West Virginia University ( $\$ 300-500 / y r)$

2007-2009 Maxwell, R.S. NASA West Virginia Space Grant Consortium Graduate Research Fellowship (\$48,000) 
2007-2008 Maxwell, R.S. A Multi-century Tree-ring Reconstruction of Potomac River Streamflow for Water Resource Planning in the Washington, DC Metropolitan Area, Explorers Club Washington Group $(\$ 1,000)$

2007 Maxwell, R.S. Eberly College of Arts and Sciences Doctoral Student Research Grant, West Virginia University (\$700)

2007 Maxwell, R.S. American Center for Mongolian Studies Research Fellowship $(\$ 2,000)$

2006-2009 Maxwell, R.S. HERF Graduate Fellowship, Eberly College of Arts and Sciences, West Virginia University $(\$ 4,000)$

2005-2006 Maxwell, R.S. and Hicks, R.R. Rimrock pine communities at New River Gorge National River, West Virginia, National Park Service $(\$ 16,000)$

\section{Teaching Experience}

2009-2010 Graduate Teaching Assistant, West Virginia University

Geology \& Geography Department Information Technology Assistant

2009 Group Leader, $19^{\text {th }}$ Annual North American Dendroecological Fieldweek Climate Reconstruction Group

2009 Instructor, West Virginia University

GEOG

107: Physical Geography, Summer, 25 undergrads

2007 Instructor, West Virginia University

GEOG 415: Global Environmental Change, Fall, 25 undergrads, 5 grads

2006-2007 Graduate Teaching Assistant, West Virginia University

GEOG 150: Digital Earth (under Dr. Jennifer Miller)

2001 Teaching Assistant, West Virginia University

PSYC 202: Research Methods in Psychology (under Dr. Kennon Lattal)

\section{Mentoring}

2009

2009

2007

Caroline Leland, BA Environmental Geosciences, Tree-Ring Analysis

Eric Lovell, BA Geography, Tree-Ring Analysis

Carrie Scott, BA Geography, Tree-Ring Analysis

\section{Departmental and University Service}

$2008 \quad$ Organizer, WVU Geography Colloquium

2007-2009 Graduate Student Representative, WVU Geology and Geography Department

2007-2008 President, WVU Geography Graduate Group

\section{$\underline{\text { Professional Service }}$}

2010 Session Organizer/Chair, "Advocacy in Biogeographic Science", Association of American Geographers Annual Meeting, Washington, D.C. 
2010 Session Chair, "Dendroclimatology", Association of American Geographers Annual Meeting, Washington, D.C.

2009

2009-2010 Panelist, WVU Geography Colloquium "Grants and External Funding"

2009 Reviewer, Canadian Journal of Forest Research

2009 Presenter, Wetlands Field Day (Wirt County School, WV)

\section{Memberships}

American Center for Mongolian Studies

Association of American Geographers

Biogeography Specialty Group

Graduate Student Affinity Group

Paleoenvironmental Change Specialty Group

Water Resources Specialty Group

Society of American Foresters

Ecological Society of America

\section{Other Experience}

$2008 \quad$ Participant, $18^{\text {th }}$ Annual North American Dendroecological Fieldweek

2008 Participant, Introduction to Exploratory Spatial Data Analysis Workshop

2005 Participant, $15^{\text {th }}$ Annual North American Dendroecological Fieldweek 